ICTD Research Report 3

\section{Unitary Taxation in Federal and Regional Integrated Markets}

Erika Dayle Siu with Milly Isingoma Nalukwago, Rachmanto Surahmat and Marcos Aurélio Pereira Valadão

September 2014 
Unitary Taxation in Federal and Regional Integrated Markets

Erika Dayle Siu with Milly Isingoma Nalukwago, Rachmanto Surahmat and Marcos Aurélio Pereira Valadão ICTD Research Report 3

First published by the Institute of Development Studies in September 2014

(C) The Authors, 2014

ISBN: 978-1-78118-177-5

The authors of this paper grant to the IDS and the ICTD a perpetual, irrevocable, worldwide, royalty-free, non-exclusive licence, or sublicence, to reproduce, communicate to the public, use, adapt, publish, distribute, display and transmit the work in any and all media, and to sublicense others (including the Crown) to reproduce, communicate to the public, use, adapt, publish, distribute, display and transmit the work in any and all media, for non-commercial purposes and with appropriate credit being given to the authors and ICTD funders.

A catalogue record for this publication is available from the British Library.

This work has been licensed by the copyright holder for distribution in electronic format via any medium for the lifetime of the OpenDocs repository for the purpose of free access without charge and can be found at http://opendocs.ids.ac.uk/opendocs/

Also available from:

The International Centre for Tax and Development

at the Institute of Development Studies,

Brighton BN1 9RE, UK

Tel: +44 (0) 1273606261 Fax: +44 (0) 1273621202

E-mail: info@ictd.ac.uk

Web: www.ictd/en/publications

IDS is a charitable company limited by guarantee and registered in England (No. 877338) 


\title{
Unitary Taxation in Federal and Regional Integrated Markets
}

\author{
Erika Dayle Siu with Milly Isingoma Nalukwago, Rachmanto Surahmat and
} Marcos Aurélio Pereira Valadão

\section{Summary}

This paper analyses and compares approaches to unitary taxation in federal and regional integrated markets, and explores the potential application of unitary taxation in the context of regional economic communities within Africa, East Asia, and Latin America. The federal models to be examined are the systems of unitary taxation in practice in the United States (US), Argentina, Canada and Switzerland. The primary regional model to be examined is the Common Consolidated Corporate Tax Base (CCCTB), now proposed in the European Union (EU). Finally, this paper extrapolates lessons learned and explores the potential application of unitary taxation in the Association of Southeast Asian Nations (ASEAN), the East African Community (EAC), and Mercosur and the Andean Community (CAN) in the Latin American region.

Keywords: unitary taxation; formulary apportionment; tax consolidation; combined reporting; Switzerland tax system; Canada tax system; Common Consolidated Corporate Tax Base; EU CCCTB; US tax system; Argentina gross income tax.

Erika Dayle Siu is a Tax Research Consultant, and has worked for the United Nations on a project to exchange successful tax practices among developing countries. She holds an LL.M. from New York University School of Law.

Milly Isingoma Nalukwago is a Business Analysis Manager with the Uganda Revenue Authority (URA). She is the URA Representative/chairperson on the research and planning subcommittee of the East Africa Revenue Authorities Technical Committee.

Rachmanto Surahmat is Senior Advisor, Tax Services at Ernst \& Young, Indonesia. He is Chairman of the International Fiscal Association (Indonesian Branch); a Lecturer at the University of Indonesia; former Indonesian Tax Administration, Director of International Taxation and Treaty Negotiation Team Leader, 1993-2001; and graduate of the International Tax Program at Harvard University.

Marcos Aurélio Pereira Valadão is Professor of Law at the Universidade Católica de Brasília, with an S.J.D. from SMU in the US, LL.M. from UnB, Brazil, LL.M. International and Comparative Law from SMU in the US, and LL.B. from PUC-GO, Brazil. He is Chair of the 1st Section of the Federal Administrative Court of Tax Appeals (CARF - Brazil). 


\section{Contents}

Summary $\quad 3$

$\begin{array}{ll}\text { Acknowledgements } & 7\end{array}$

$\begin{array}{ll}\text { Acronyms } & 7\end{array}$

$\begin{array}{lr}\text { Introduction } & 9\end{array}$

$1 \quad$ Unitary tax approaches in federal and regional integrated markets 12

$\begin{array}{ll}1.1 & \text { Corporate gross receipts apportionment in Argentina } \\ & 12\end{array}$

$\begin{array}{ll}\text { 1.1.1 Political overview } & 12\end{array}$

1.1.2 Tax base harmonisation $\quad 13$

1.1.3 Tax base consolidation $\quad 13$

1.1.4 Tax base allocation $\quad 14$

1.1.5 Administration, reporting and dispute resolution 16

1.1.6 Conclusion $\quad 17$

$\begin{array}{lll}1.2 & \text { Corporate income allocation in Canada } & 17\end{array}$

1.2.1 Political overview 17

1.2.2 Tax base harmonisation $\quad 17$

1.2.3 Tax base consolidation $\quad 18$

1.2.4 Tax base allocation $\quad 19$

1.2.5 Administration and reporting 20

1.2.6 Conclusion 20

1.3 Corporate income apportionment in the European Union under the

1.3.1 Political overview $\quad 21$

1.3.2 Tax base harmonisation $\quad 24$

1.3.3 Tax base consolidation $\quad 26$

1.3.4 Tax base apportionment $\quad 27$

1.3.5 Administration, reporting and dispute resolution $\quad 29$

1.3.6 Conclusion $\quad 30$

1.4 Corporate income apportionment in Switzerland 30

1.4.1 Political overview 30

1.4.2 Tax base harmonisation 32

1.4.3 Tax base consolidation $\quad 32$

1.4.4 Tax base allocation and apportionment 33

1.4.5 Administration, reporting and dispute resolution 35

1.4.6 Conclusion $\quad 36$

1.5 Corporate income apportionment in the United States 36

1.5.1 Political overview 36

1.5.2 Tax base harmonisation $\quad 40$

1.5.3 Tax base consolidation $\quad 40$

1.5.4 Tax base allocation and apportionment $\quad 42$

1.5.5 Administration, reporting and dispute resolution $\quad 46$

1.5.6 Conclusion $\quad 47$

2 Comparison and lessons learned from unitary tax approaches in federal and regional integrated markets

2.1 Tax jurisdiction 47

2.2 Tax base harmonisation 48

2.3 Tax base consolidation 48

2.4 Tax base apportionment and/or allocation 49

$\begin{array}{lll}2.5 & \text { Reporting requirements } & 50\end{array}$

2.6 Lessons learned 50

2.7 Conclusion 52 
Potential application of unitary tax approaches to regional integrated markets of the Global South

3.1 The ASEAN region 56

3.1.1 Political overview 56

3.1.2 The deemed profits method 56

3.1.3 Unitary taxation and deemed profits $\quad 57$

3.1.4 Necessary steps towards a unitary taxation approach 58

3.1.5 Conclusion $\quad 58$

3.2 The East African Community 62

3.2.1 Political overview 62

3.2.2 Application of a unitary approach for the EAC 64

3.2.3 Conclusion 66

3.3 Latin America - Mercosur and the Andean Community 69

3.3.1 Mercosur: historical background (LAFTA and LAIA) 69

3.3.2 Mercosur: current status and perspectives $\quad 70$

3.3.3 Mercosur: country-by-country analysis 71

3.3.4 Application of a unitary approach for Mercosur 75

3.3.5 CAN: historical background $\quad 75$

3.3.6 CAN: current status and perspectives $\quad 77$

3.3.7 CAN: country-by-country analysis $\quad 77$

3.3.8 Application of a unitary approach for CAN 79

3.3.9 Challenges for the application of a unitary approach for
CAN and Mercosur

3.3.10 Conclusion 80

4 Conclusion $\quad 83$

$\begin{array}{lr}\text { References } & 84\end{array}$

Tables

Table 1

Table 2

Table 3

Table 4

Table 5

Table 6

Table 7

Table 8

Table 9

Table 10

Table 11

Table 12

Table 13

Table 14

Table 15

Table 16
Special apportionment formula rules for selected industries in Argentina Special allocation formula rules in Canada

CCCTB special apportionment formula rules for selected industries

Special apportionment formula rules in Swiss cantons

Multi-state compact apportionment formula rules for selected industries

Comparison of systems of unitary taxation and formulary apportionment

Comparison of apportionment formulae and factors

Deemed profits schedule

Summary of taxes in six ASEAN countries

Transfer pricing guidelines in six ASEAN countries

Summary of taxes in the EAC 2012/13

Transfer pricing guidelines in the EAC region

Foreign direct investment flows to the EAC region in USD million

Brazilian transfer pricing approach

Mercosur transfer pricing legislation by country - current stage and other features

CAN transfer pricing legislation by country - current stage and other features

16

19

28

35

46

53

54

57

59

61

67

68

68

73

81

82

Chart

Chart 1 


\section{Diagrams}

Diagram 1

Diagram 2

Corporate group taxation spectrum

Diagram 3

Unitary taxation approach spectrum

Tax base definition, consolidation and apportionment of GIT in Argentine provinces

Diagram 4 Tax base definition, consolidation and allocation in Canadian provinces CCCTB tax base definition, consolidation, allocation and apportionment Tax base definition, consolidation, allocation and indirect apportionment in Swiss cantons

Diagram 7 Tax base definition, consolidation, allocation and apportionment in US states

Diagram 8 Comparison of corporate income tax systems by aggregation level 


\section{Acknowledgments}

We would like to thank the International Centre for Taxation and Development (ICTD) for funding this research programme and for hosting the research meetings for the Unitary Taxation research group. We also appreciate the kind assistance of the following individuals for reviewing and commenting on sections of this paper: Sol Picciotto, Alan Carter, Walter Hellerstein, Jack Mintz, loanna Mitrogianni, and Spencer Moore. All errors are ours.

\section{Acronyms}

\begin{tabular}{|c|c|}
\hline AEC & ASEAN Economic Community \\
\hline APA & Advance Pricing Agreement \\
\hline ASEAN & Association of Southeast Asian Nations \\
\hline BEPS & Base Erosion and Profit Shifting \\
\hline CACM & Central American Common Market \\
\hline CAN & Andean Community \\
\hline CARICOM & Caribbean Community \\
\hline СССТВ & Common Consolidated Corporate Tax Base \\
\hline CCM & Mercosur Trade Commission \\
\hline CFC & Controlled Foreign Company \\
\hline CIT & Corporate Income Tax \\
\hline CMC & Common Market Council \\
\hline CPC & Joint Parliamentary Group \\
\hline CPM & Cost Plus Method \\
\hline CSLL & Social Contribution on the Net Profit \\
\hline CUP & Comparable Uncontrolled Price \\
\hline DC & District of Columbia \\
\hline DTA & Double Taxation Agreement \\
\hline EAC & East African Community \\
\hline EARACG & East African Revenue Authorities Commissioner Generals \\
\hline EARATC & East African Revenue Authority Technical Committee \\
\hline $\mathrm{EC}$ & European Commission \\
\hline EPZ & Export Processing Zone(s) \\
\hline EU & European Union \\
\hline FCES & Economic and Social Consultative Forum \\
\hline FTAA & Free Trade Area of the Americas \\
\hline GIT & Gross Income Tax \\
\hline GIZ & Deutsche Gesellschaft für Internationale Zusammenarbeit \\
\hline GDP & Gross Domestic Product \\
\hline GMC & Common Market Group \\
\hline GTZ & Deutsche Gesellschaft für Technische Zusammenarbeit \\
\hline ICT & Irish Corporation Tax \\
\hline IFC & International Finance Corporation \\
\hline IFRS & International Financial Reporting Standards \\
\hline ITA & Indonesian Tax Authority \\
\hline ITL & Income Tax Law \\
\hline LAFTA & Latin American Free Trade Association \\
\hline LAIA & Latin American Integration Association \\
\hline Mercosur & Common Market of the South \\
\hline MNE & Multinational Enterprise \\
\hline MS & Member States \\
\hline
\end{tabular}




$\begin{array}{ll}\text { MTC } & \text { Multistate Tax Compact } \\ \text { NAFTA } & \text { North American Free Trade Agreement } \\ \text { NC } & \text { National Constitution } \\ \text { OECD } & \text { Organisation for Economic Cooperation and Development } \\ \text { PE } & \text { Permanent Establishment } \\ \text { PIT } & \text { Personal Income Tax } \\ \text { PS } & \text { Partner States } \\ \text { PSM } & \text { Profit Split Method } \\ \text { RA } & \text { Revenue Authority } \\ \text { RADDEx } & \text { Revenue Authorities Digital Data Exchange } \\ \text { RPM } & \text { Resale Price Method } \\ \text { SCT } & \text { Single Customs Territory } \\ \text { SEZ } & \text { Special Economic Zone(s) } \\ \text { SICA } & \text { Central American Integration System } \\ \text { SM } & \text { Mercosur Secretariat } \\ \text { TEC } & \text { Common External Tariff } \\ \text { TEU } & \text { Treaty on the European Union } \\ \text { TFEU } & \text { Treaty on the Functioning of the European Union } \\ \text { TNMM } & \text { Transactional Net Margin Method } \\ \text { TP } & \text { Transfer Pricing } \\ \text { UDITPA } & \text { Uniform Division of Income for Tax Purposes Act } \\ \text { UNASUR } & \text { Union of South American Nations } \\ \text { US } & \text { United States } \\ \text { UT } & \text { Unitary Taxation } \\ \text { VAT } & \text { Value Added Tax } \\ \text { WWCR } & \text { Worldwide Combined Reporting } \\ \end{array}$




\section{Introduction}

\section{Unitary taxation defined}

Unitary taxation is an approach to taxation of corporate income which arises from the notion that a unitary business is greater than the sum of its parts. ${ }^{1}$ This means that the net income of a single legal entity, which is part of a larger corporate group engaged in the same business, represents more than the profits attributable to that single entity. In economic terms, the economies of scale and reduced transaction and marketing costs associated with the corporate form create value that cannot easily be separated among constituent parts (Coase 1937). Moreover, the economic rationale for international production stems from the ability of the multinational enterprise (MNE) to act as an efficient coordinator of geographically dispersed factors of production (Dunning 1988: 11). Thus, in this sense, a unitary taxation approach reflects the economic unity of the modern corporate enterprise.

Under a unitary taxation approach, in order for a state to exercise taxing jurisdiction over the income of a corporation that corporation must have a taxable business activity within the state. If this condition is met, the state determines the taxable income of all the relevant members of a unitary corporate group by first aggregating the income of the unitary business activities and then apportioning or 'sharing out' the group's worldwide net income based on certain economically significant factors, such as the property, payroll and sales in the taxing state. Unitary taxation does not attempt to attribute income as earned by the component parts of a unitary business, but instead assumes that the total income is due to the combined activities and synergies of the whole and taxes on the basis of factors of production and consumption, which quantify the group's business activities in the state.

Associated with the unitary taxation approach is the concept of 'corporate group taxation', which consolidates the tax bases of affiliated corporations. ${ }^{2}$ Corporate group taxation may be envisioned along a spectrum. Limited combination of profit/loss after separate accounting by corporate entities occurs in loss transfer systems and would be reflected at the low end of the spectrum of tax base aggregation. Complete combination of income, expenses and tax attributes across the corporate group occurs in full consolidation systems, and would be reflected at the high end of the spectrum. Several countries employ loss transfer systems at the national level with varying degrees of tax consolidation. ${ }^{3}$ (See Diagram 1.)

Aristotle, Metaphysics, Book H 1045a: 8-10: 'the totality is not, as it were, a mere heap, but the whole is something besides the parts'.

Consolidation for tax purposes, as used in this paper, is a distinct concept from consolidation as used in accounting statements. Moreover, the terms 'consolidation', 'aggregation' and 'combination' are used interchangeably.

Australia, Denmark, Finland, France, Germany, Italy, Japan, the Netherlands, the UK and the US employ systems along this spectrum. The fiscal unity system employed in the Netherlands functions on the basis of balance sheet (accounting) consolidation. In this system, a national corporate group consolidates all balance sheet items and then adjusts for taxation. Under the proposed EU CCCTB, however, individual group members' profit and loss accounts are translated into tax accounts based on the common rules of the directive first before being merged to produce the consolidated tax base, which is then apportioned across all group members. Thus, the loss transfer system of the Netherlands involves consolidation at an earlier 'accounting' stage, while the EU CCCTB involves consolidation of the tax base only. 


\section{Diagram 1 Corporate group taxation spectrum}

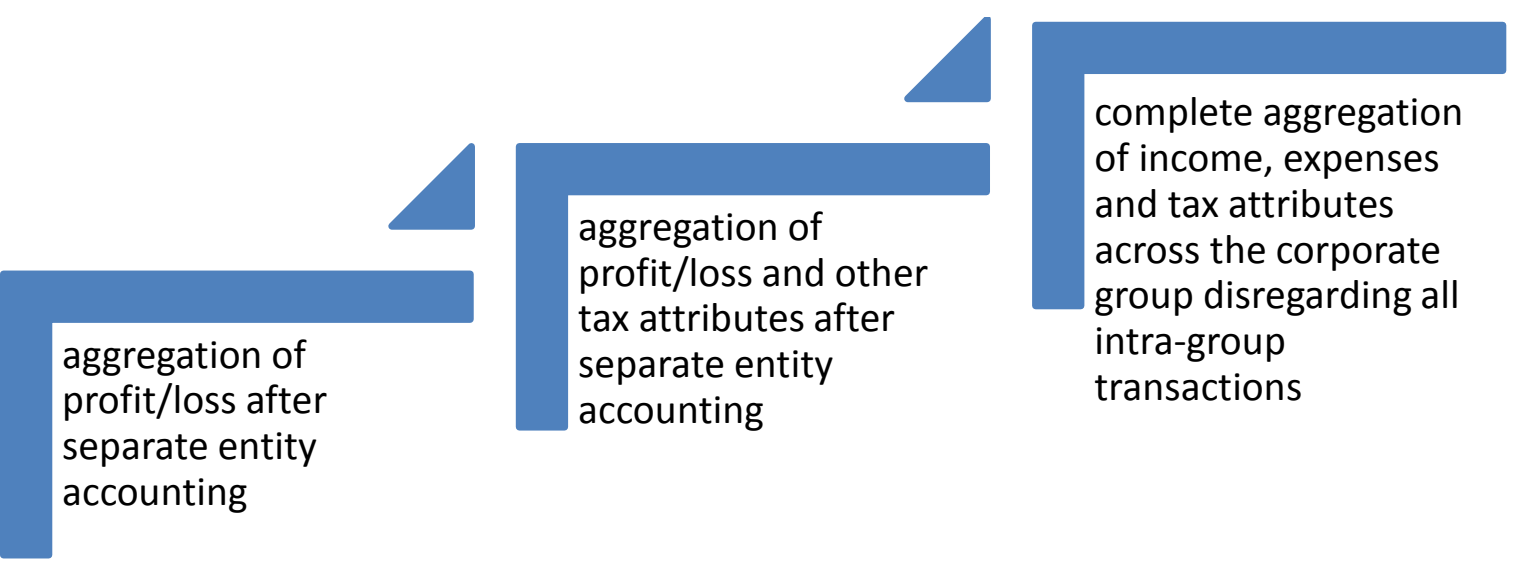

Some scholars use the term 'unitary' to refer exclusively to systems that define a corporate group according to the unitary business principle and then combine the tax base (see step 3 of the above diagram). ${ }^{4}$ Moreover, other scholars use the term 'formulary apportionment' to refer exclusively to systems which apportion the tax base regardless of the method of aggregation. ${ }^{5}$ In this analysis, however, we treat the entire spectrum of cross-border aggregation, consolidation and combination, along with the sharing out of the tax base, as unitary approaches, because at the foundational level, given a certain threshold of integration, the corporation and its business activities are considered part of an economic unit regardless of the location of the activity or the legal form under which these activities are conducted. Hence the combined tax base of this unit should be shared by taxing jurisdictions in proportion to the actual economic activities carried out within their respective borders.

As a result, this analysis extends the unitary classification to the systems of Argentina, Canada and Switzerland, which aggregate the cross-border tax base within the legal entity only (i.e. within the legally defined corporation and its branches/divisions/permanent establishments (PEs) but not subsidiaries or other affiliated corporations). These systems are classified under the unitary approach spectrum because there is cross-border aggregation before apportionment. (See Diagram 2.)

See, e.g., Weiner (2005: 26-27). Weiner notes the distinction between 'consolidation', i.e. legal integration, and 'combination', i.e. economic integration.

5 See, e.g., Hellerstein (2005: 105): 'Formulary apportionment is compatible with - but by no means required by consolidated reporting, at least as a matter of principle'. 


\section{Diagram 2 Unitary taxation approach spectrum}

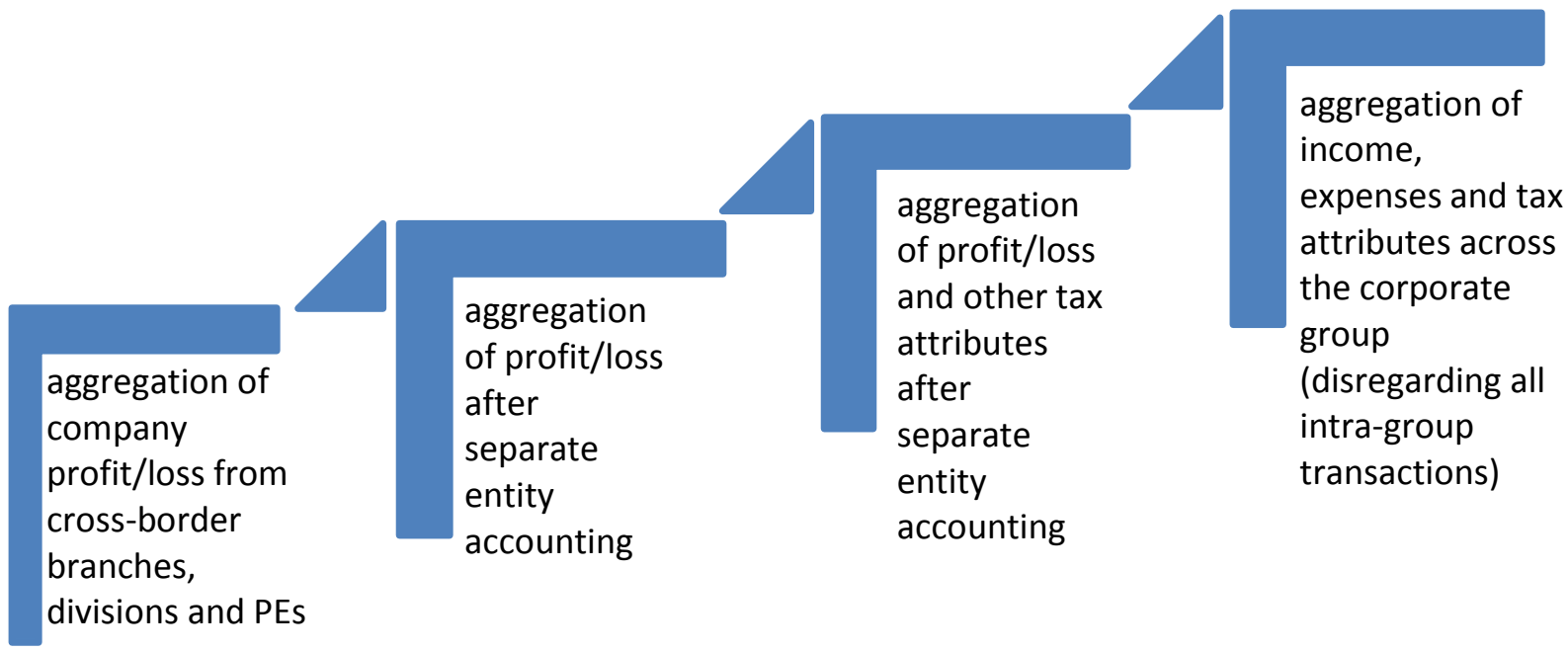

After the corporate group is defined and the tax base is consolidated, this tax base is shared through an allocation mechanism (either directly to taxing jurisdictions or indirectly to the taxing jurisdictions through the corporate group members). In a typical three-factor apportionment formula the worldwide net income of a unitary business is multiplied by a fraction, which represents the average of the ratios of in-state sales, payroll and property to worldwide sales, payroll and property.

In terms of reporting requirements, any state in which any part of the corporate group has a taxable presence may require the corporate group to submit a combined report of its worldwide and in-state income. Thus, instead of seeing only a separate account of income sourced in the taxing state by separate legal entities, a taxing authority can use the combined report to assess tax on the proportion of the group's net income from a unitary business attributable to the group's in-state economic activities.

\section{Economic integration and tax coordination}

Schematically, the economic integration process begins through the establishment of a preferential trade area in the form of reduced customs tariffs between countries, developing into a free trade area and customs union with common external tariffs trade policy. A common market with product regulations and the free movement of goods, capital, labour and services may then be established, and perhaps even an economic and monetary union with a single market, currency and monetary policy. Only at a fairly developed stage of integration are economic and fiscal policies, such as direct taxation, likely to be harmonised (Balassa 1961). ${ }^{6}$

In federal systems of government, where subnational entities exercise taxation jurisdiction by assessing corporate income taxes, arrangements for apportioning taxable profits developed very early in the process of market integration, particularly in the US, Switzerland and Canada. This allocation of taxable profits among subnational jurisdictions was necessary in these unified markets to ensure low or no barriers to the movement of goods and services, freedom of movement of capital including the right of establishment for corporations, while also ensuring an equitable sharing of the tax base among states. The quid pro quo for granting out-of-state firms free access to do business in a state was that firms should be

Equalisation structures also play a role in economic integration and may compensate for deficiencies in tax coordination and harmonisation, but this interplay is beyond the scope of this research. 
taxed by each state on a proportion of the profits gained from exploiting the benefits of an integrated market. Further, in the absence of adequate tax coordination, market competition among the subnational entities would likely lead to a race to the bottom due to the temptation to create new barriers to market access, and as a result the internal market would remain segmented and all subnational entities would face problems in safeguarding revenue. ${ }^{7}$ Thus, tax coordination was recognised as a necessity in order to exercise tax sovereignty while reaping the benefits of economic integration.

In addition to these federal integrated markets, closer tax coordination may be both necessary and an important policy tool for regional integrated markets. In particular, the European Union (EU) has developed a proposal for a CCCTB, which was approved by the European Parliament in 2012 and is currently under consideration by the Council of Ministers. Other regions are also considering closer tax coordination in their agenda for economic integration. For example, the revenue authorities of the EAC are currently investigating improved tax harmonisation and coordination.

This paper analyses federal and regional integrated market applications of unitary taxation, and explores potential applications of unitary taxation in regional economic communities of the Global South. Section one examines the federal system of unitary taxation in practice in Argentina, Canada, Switzerland and the US, and a regional model for unitary taxation, the CCCTB, now proposed in the EU. Each unitary taxation approach will be examined in terms of tax base harmonisation, consolidation and apportionment, as well as reporting requirements. Section two compares these approaches according to the same framework and extracts lessons learned. Finally, section three explores potential applications of unitary taxation in ASEAN, EAC, and Mercosur and CAN in Latin America. Drawing on existing economic agreements within these communities, this paper explores the advantages, challenges and solutions to adoption of a regional unitary taxation approach.

\section{Unitary tax approaches in federal and regional integrated markets}

\subsection{Corporate gross receipts apportionment in Argentina ${ }^{8}$}

\subsubsection{Political overview}

Argentina is a representative democracy, republican and federal state with a population of 41 million. It is composed of twenty-three provinces and an autonomous city, Ciudad de Buenos Aires. ${ }^{9}$ The National Constitution assigns taxing power to both the national government and the provinces. Only the national government can impose import and export tariffs, ${ }^{10}$ and both the national government and the provinces can impose consumption taxes. ${ }^{11}$ The provinces may also impose taxes on income and wealth. The national government may do so only for a

\footnotetext{
$7 \quad$ This market competition in the US colonial context was largely evidenced in import tariffs between states. James Madison even noted that some states, such as Connecticut, taxed imported goods from Massachusetts higher than those imported from Great Britain. James Madison, 'Preface to Debates in the Convention of 1787', in Farrand (1911: 547-48). After the revolution and creation of the common market, continued competition came in the form of licence fees for out-of-state businesses. See, e.g., Ward v. Maryland, 79 US 418 (1870) (statute, imposing tax on non-resident traders through licence fees struck down as unconstitutional).

$8 \quad$ Many thanks to Karina Tchrian, Inter-American Development Bank, and Professor Marcos Aurélio Pereira Valadão of the Catholic University of Brasilia, who provided much of the content for this section.

$9 \quad$ Article 1, National Constitution (NC). Although Ciudad de Buenos Aires is not technically a province, I will use the term provinces as referring also to Ciudad de Buenos Aires.

Articles 4, 75.1, 75.2, NC.

Article 75.2, NC.
} 
limited period of time, proportionately in all the country, and as long as it is needed for reasons related to defence, common safety and the general public good. ${ }^{12}$

However, the de facto distribution of taxing power between the national government and the provinces is very different from the constitutional design. Since the provinces have yielded most of their taxing power to the national government, value added tax (VAT) and income tax are imposed and collected at the national level. However, the provinces still impose Gross Income Tax (GIT), which is an indirect turnover tax. In 1977, the national government established a tax revenue-sharing agreement among the national government and the provinces which limited the taxing power of the provinces. ${ }^{13}$ According to Article 9 of the agreement, provinces that join the tax revenue-sharing agreement cannot impose taxes analogous to those that are imposed by the national government and that are shared. Article 9 expressly excludes from this prohibition some provincial taxes such as GIT, real estate taxes, taxes on the ownership of cars and stamp tax. It is important to note, however, that this restriction on the provinces' power to tax does not have a constitutional basis. ${ }^{14}$ As a result of this law, provinces apply the Multilateral Agreement (Convenio Multilateral) in apportioning the GIT taxable base. ${ }^{15}$

\subsubsection{Tax base harmonisation}

Under GIT, provinces have jurisdiction to tax gross receipts of a unitary business realised through a physical presence in the province, as well as receipts through independent agents or travelling salespersons. GIT is usually collected as a percentage of all sales of a business, except in the case of special sectors. Business costs, losses or other tax allowances are not subtracted from the tax base. As a result, there is a high degree of harmonisation.

\subsubsection{Tax base consolidation}

GIT is usually collected as a percentage (generally not higher than 4 per cent) of all sales of a business. When a taxpayer does business or carries out activities in more than one province, provinces apply a facts and circumstances analysis to determine whether the gross income is derived from an economically inseparable unitary process according to the following criteria:

(i) manufacturing takes place in one province(s) and the sale of products takes place in another/others;

(ii) manufacturing and/or sales take place in one province(s) and management and administration take place in another/others;

(iii) the principal place of business is located in one province and sales and purchases occur in another/others;

(iv) the principal place of business is in one province and the rendering of services regarding individuals and goods takes place in another/others. ${ }^{16}$

There is no consolidation of income from separate legal entities: the taxpayer under GIT regulations is the company and its branches within Argentina. However, when a company

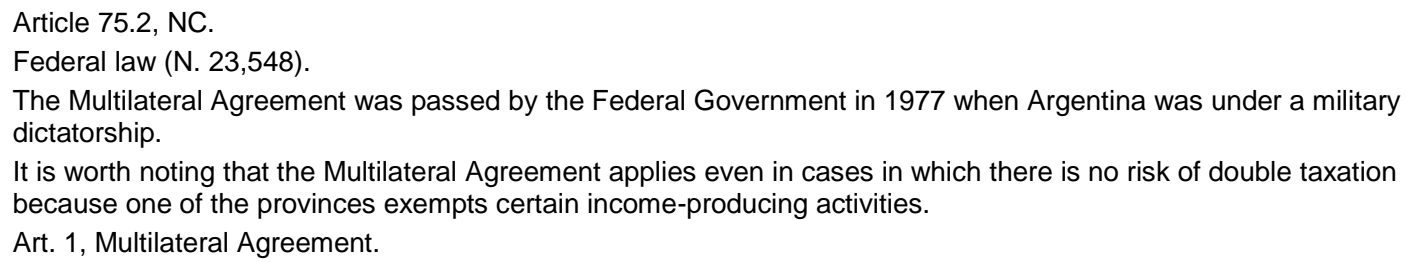


conducts business activities in more than one province, and the gross income is derived from an economically inseparable unitary process, this income is consolidated among the crossborder branches. Moreover, gross revenue includes sales made by the taxpayer himself as well as sales made through third parties, including by intermediaries, brokers, agents or representatives. Sales are deemed to take place at the point of destination. (See Diagram 3.)

\section{Diagram 3 Tax base definition, consolidation and apportionment of GIT in Argentine provinces}

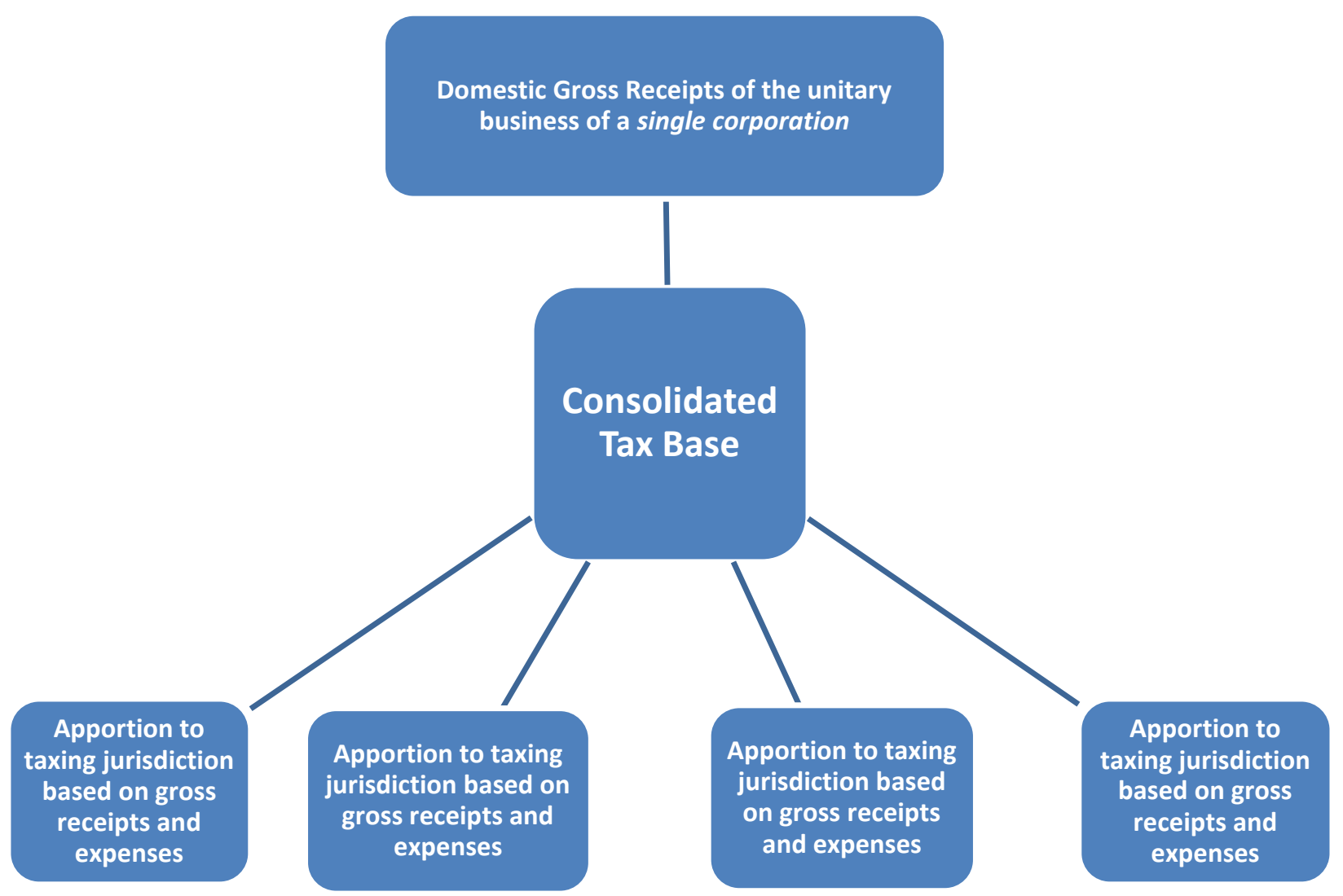

\subsubsection{Tax base allocation}

Under the Multilateral Agreement, a taxpayer's total gross income will be apportioned among the different provinces according to the following rules:

(i) 50 per cent in proportion to the expenses which are effectively borne in each province and connected to the unitary income-producing business activity;

(ii) 50 per cent in proportion to the gross income which is derived from each province, including sales realised through branches, agencies, PEs, brokers, commission agents, agents, travelling salespersons, without regard to whether they are employees of the taxpayer, and which is connected to the unitary income-producing business activity.

These rules may be translated into the following formula:

Taxable base of Province $A=[($ Expenses in Province $A /$ total expenses from all provinces $)+$ (gross income in province A/total gross income from all provinces)]/2 


\section{Definition of gross income}

The income to which the Multilateral Agreement refers is the income to which GIT applies, even if certain income has been exempted from the tax or if the rate applied to it is zero. ${ }^{17}$ Income allocated to the jurisdiction is destination-based.

\section{Eligible expenses}

The expenses to which the Multilateral Agreement refers are those that are attributable to the business activity. These expenses include salaries, daily wages and any other remuneration, fuel, rent, insurance premiums, and, in general, any purchase, administration, production, or sales-related expense, and depreciation that may be deducted under the income tax law. However, the expenses that will not be considered for the determination of the taxable base of each jurisdiction include the cost of raw materials in industrial activities or the cost of merchandise in commercial activities. The term 'raw materials' includes any goods or rights that are physically incorporated or added to the finished product. In addition, the costs of works and services that are related to the commercialisation of the finished product, publicity costs, national, provincial and municipal taxes, and loan interest and fees paid to managers, auditors and partners of corporations when they exceed a certain threshold, will not be considered expenses when determining the taxable base attributable to each province.

According to the Multilateral Agreement, an expense will be considered 'borne by a jurisdiction' when it is directly related to the activity that takes place in that jurisdiction, even if the outlay related to the expense takes place in a different jurisdiction. Thus, salaries, wages and other remunerations are borne by the jurisdiction in which the services are rendered even if the payments are made in another jurisdiction. ${ }^{18}$ Those expenses that cannot be attributed according to these criteria will be distributed in the same proportion as the rest of the expenses provided they are of low significance. If those expenses are significant the taxpayer must distribute them reasonably. Transportation costs will be attributed equally to all the jurisdictions involved. ${ }^{19}$ The taxable base will be distributed using the gross income and expenses that are reflected in the last closed balance sheet in the previous calendar year. If the taxpayer is not required to keep balance sheets, the distribution will contemplate the gross income and expenses of the previous calendar year. ${ }^{20}$

\section{Special allocation formulae}

The Multilateral Agreement also contains special rules for construction, insurance, financial, transportation, professional services and other sectors. In these cases, the law provides fixed percentages that must be applied to split the tax base among different jurisdictions. In addition, a special regime applies to the start-up and cessation of business activities. (See Table 1.)

In Argentina there is a distinction between 'excluded income' and 'exempt income'. Excluded income is not part of the tax base; exempt income is part of the tax base but there are reasons to not actually apply the tax.

Art. 4, Multilateral Agreement.

Art. 4, Multilateral Agreement.

Art. 5, Multilateral Agreement. 
Table 1 Special apportionment formula rules for selected industries in Argentina

\begin{tabular}{|c|c|}
\hline \multicolumn{2}{|c|}{ Special apportionment formula rules for selected industries in Argentina } \\
\hline Industry & Special rule \\
\hline Financial organisations & $\begin{array}{l}\text { In the case of taxpayers falling within the Financial Institutions Act, each } \\
\text { jurisdiction may tax the revenue in proportion to the sum of revenue and passive } \\
\text { interests of authorised offices or branches in its territory. The revenue from } \\
\text { operations in jurisdictions where entities do not have authorisation to work will be } \\
\text { attributed entirely to the jurisdiction in which the transaction has taken place (Art. } \\
8 \text {, Multilateral Agreement) }\end{array}$ \\
\hline Transportation & $\begin{array}{l}\text { Passenger and cargo transport companies which operate in several jurisdictions } \\
\text { may be taxed in each on the gross income for the price of the tickets according } \\
\text { to the place of origin of the trip or freight (Art. 9, Multilateral Agreement) }\end{array}$ \\
\hline Construction & $\begin{array}{l}\text { For taxpayers performing construction activities including demolition, excavation, } \\
\text { drilling, etc., having a place of management in a jurisdiction and performing their } \\
\text { activities in other jurisdictions, income shall be attributed } 10 \% \text { to the jurisdiction } \\
\text { where the office is established, and } 90 \% \text { to the jurisdiction in which the work is } \\
\text { performed (Art. } 6 \text {, Multilateral Agreement) }\end{array}$ \\
\hline Professional services & $\begin{array}{l}\text { For professional services exercised by persons having an office in one } \\
\text { jurisdiction and delivered in another, the jurisdiction in which the activity is } \\
\text { performed may charge } 80 \% \text { of the fees collected or accrued there, and the other } \\
\text { jurisdiction the remaining } 20 \% \text {. The same treatment applies to consultants and } \\
\text { consulting firms (Art. 10, Multilateral Agreement) }\end{array}$ \\
\hline Insurance & $\begin{array}{l}\text { Insurance companies, credit companies, capitalisation companies, and savings } \\
\text { and loan companies (which are not taxed as financial activities), when the } \\
\text { management or central office is in one jurisdiction and they are engaged in } \\
\text { transactions involving property or persons located or resident in another } \\
\text { jurisdiction, there shall be attributed to this jurisdiction } 80 \% \text { of income from these } \\
\text { operations, and } 20 \% \text { to the jurisdiction where administration or headquarters is } \\
\text { located (Art. 7, Multilateral Agreement) }\end{array}$ \\
\hline Others & $\begin{array}{l}\text { There are other economic activities that are subject to special rules, such as: } \\
\text { mortgage lenders that are not organised in corporate form; sugar wine } \\
\text { industries, tobacco industry; agricultural, forestry, mining and/or fruits of the } \\
\text { country, produced in one jurisdiction to be industrialised or sold outside the } \\
\text { jurisdiction producer; and transfer of gas by pipeline }\end{array}$ \\
\hline
\end{tabular}

\subsubsection{Administration, reporting and dispute resolution}

Consolidated tax returns are filed annually and payment is made to the residence state (provincia) of the taxpayer. The application and enforcement of the Multilateral Agreement is in the hands of the Plenary Commission and the Arbitral Commission. ${ }^{21}$ However, the tax agencies of each province are fully entitled to audit resident taxpayers. ${ }^{22}$ The Plenary Commission has two representatives from each province that adheres to the Multilateral Agreement. The Plenary Commission must, among other things, appoint the president and vice president of the Arbitral Commission, resolve appeals brought against decisions of the Arbitral Commission, and propose changes to the Multilateral Agreement. ${ }^{23}$ The Arbitral Commission is composed of a president, a vice president and seven board members - one representing the City of Buenos Aires, one the Province of Buenos Aires, and five representing five different groups of provinces. ${ }^{24}$ The Arbitral Commission is in charge of issuing general regulations of the Multilateral Agreement and of deciding disputes between the provinces and taxpayers. ${ }^{25}$ The Multilateral Agreement includes a non-discrimination clause which prevents provinces from applying a higher rate than the one applied to wholly local activities to activities that take place in more than one jurisdiction. ${ }^{26}$

\footnotetext{
$21 \quad$ Art. 15, Multilateral Agreement.

Art. 29, Multilateral Agreement.

Art. 16 and 17, Multilateral Agreement.

Art. 19, 20, Multilateral Agreement.

Art. 24, Multilateral Agreement.

Art. 32, Multilateral Agreement.
} 


\subsubsection{Conclusion}

GIT reflects a simplified and unitary approach to taxing the gross income of corporations. The Multilateral Agreement, under which GIT is administered, provides a harmonised definition of the tax base, uses a facts and circumstances analysis to consolidate gross income, and a two-factor uniform formula of gross receipts and expenses to apportion corporate-level gross income among the provinces of Argentina.

\subsection{Corporate income allocation in Canada}

\subsubsection{Political overview}

Canada is a federal state, governed by parliamentary democracy and constitutional monarchy, with a population of 35 million. In 1867, the British North America Act ${ }^{27}$ established a Confederation, which today comprises ten provinces and three territories. This Act also gave provinces the power to levy direct taxes within their borders and gave the federal government access to all objects of taxation. In 1876, British Columbia was the first province to impose an income tax, although some municipalities began levying income taxes as early as 1831. In order to finance Canada's involvement in World War I, in 1917 the federal government began to assess an income tax. By 1941, in the Second World War, the provinces agreed to vacate the income tax and estate tax fields in return for 'rental' payments. These tax rental agreements continued until 1962, when the federal and provincial governments (except Ontario and Quebec) entered into 'tax collection agreements' which restored the provincial income tax. Today, all provinces have tax collection agreements with the government of Canada except the provinces of Alberta and Quebec. ${ }^{28}$

Under the Federal Constitution, the federal and provincial governments have concurrent powers in the field of direct taxation. ${ }^{29}$ The Federal Income Tax Act and Part IV of the Regulations under the Income Tax Act provide rules for administering direct taxes on income and allocating the corporate income tax (CIT) base among provinces. ${ }^{30}$ The Canada Customs and Revenue Agency also publishes Income Tax Interpretation Bulletins on tax matters. ${ }^{31}$ At the subnational level, the provinces have legislation and regulations which align within federal law and provide for varying tax credits against the base. Provincial revenue administrations also publish Income Tax Interpretation Bulletins.

\subsubsection{Tax base harmonisation}

Tax jurisdiction is established through a permanent establishment (PE). ${ }^{32}$ Under the tax collection agreements, provinces are required to use the same taxable income base as the

\section{Constitution Act, 1876.}

In 1981, Alberta withdrew from the CIT agreements but remained part of the personal income tax agreements. Today, all provinces have corporation tax agreements with the Government of Canada except Quebec and Alberta. Therefore, corporations with a PE in Quebec or Alberta must file a separate provincial return.

29 Section 91(3) of the Constitution grants authority to the federal government to raise 'money by any mode or system of taxation', while also granting powers in Section 92(2) to the provinces to impose direct taxes within their borders (Constitution Acts, 1867-1982, §§91-92).

30 Note that in Canada apportionment of the tax base among provinces is referred to as allocation.

31 See, e.g., Income Tax Interpretation Bulletin IT-177R2 (Consolidated).

32 In the federal regulations, a PE is a 'fixed place of business of the corporation, including an office, a branch, a mine, an oil well, a farm, a timberland, a factory, a workshop or a warehouse'. Ownership is not enough for a PE determination; the property must be used in the business. If none of these exist, the PE is the principal place in which the business of the corporation is conducted. If the business is conducted through an employee or agent who has general authority to contract or a stock of merchandise from which orders are regularly filled, there is a deemed PE where the person is established. However, this does not extend to commission agents, brokers or other agents who only purchase merchandise. For insurance companies, registration or a licence to do business creates a PE. Ownership of land, or use of substantial machinery or equipment can also create a PE. Finally, a PE is deemed to exist at the place designated in the incorporation documents or bylaws as the head office or registered office for corporations which would not otherwise have any PE. However, PEs do not extend to subsidiaries or other affiliated legal entities. See Sec. 400(2) of the 
federal government, the same rules for determining provincial residency, and the same methods of allocating the tax base among the provinces. All provinces, including nonsignatories to the tax collection agreements, have adopted a harmonised tax base as well as a common formula for allocating the tax base. Nevertheless, the federal and provincial calculation of total tax liability can differ due to varying tax credits against the base. Each province and territory has its own tax incentive structure. All have a lower tax rate for small businesses with annual incomes under $\mathrm{C} \$ 400,000-500,000 .{ }^{33}$ Higher tax rates among the provinces range from 10 per cent to 16 per cent, with lower rates ranging from 0 per cent to 8 per cent. Provincial tax incentives are typically given to encourage political contributions, research and development, energy efficiency, job training and multimedia industry sectors. ${ }^{34}$

\subsubsection{Tax base consolidation}

Canada does not allow consolidation of income from separate legal entities. ${ }^{35}$ However, income from interprovincial PEs of a single corporation is consolidated. (See Diagram 4.)

\section{Diagram 4 Tax base definition, consolidation and allocation in Canadian provinces}

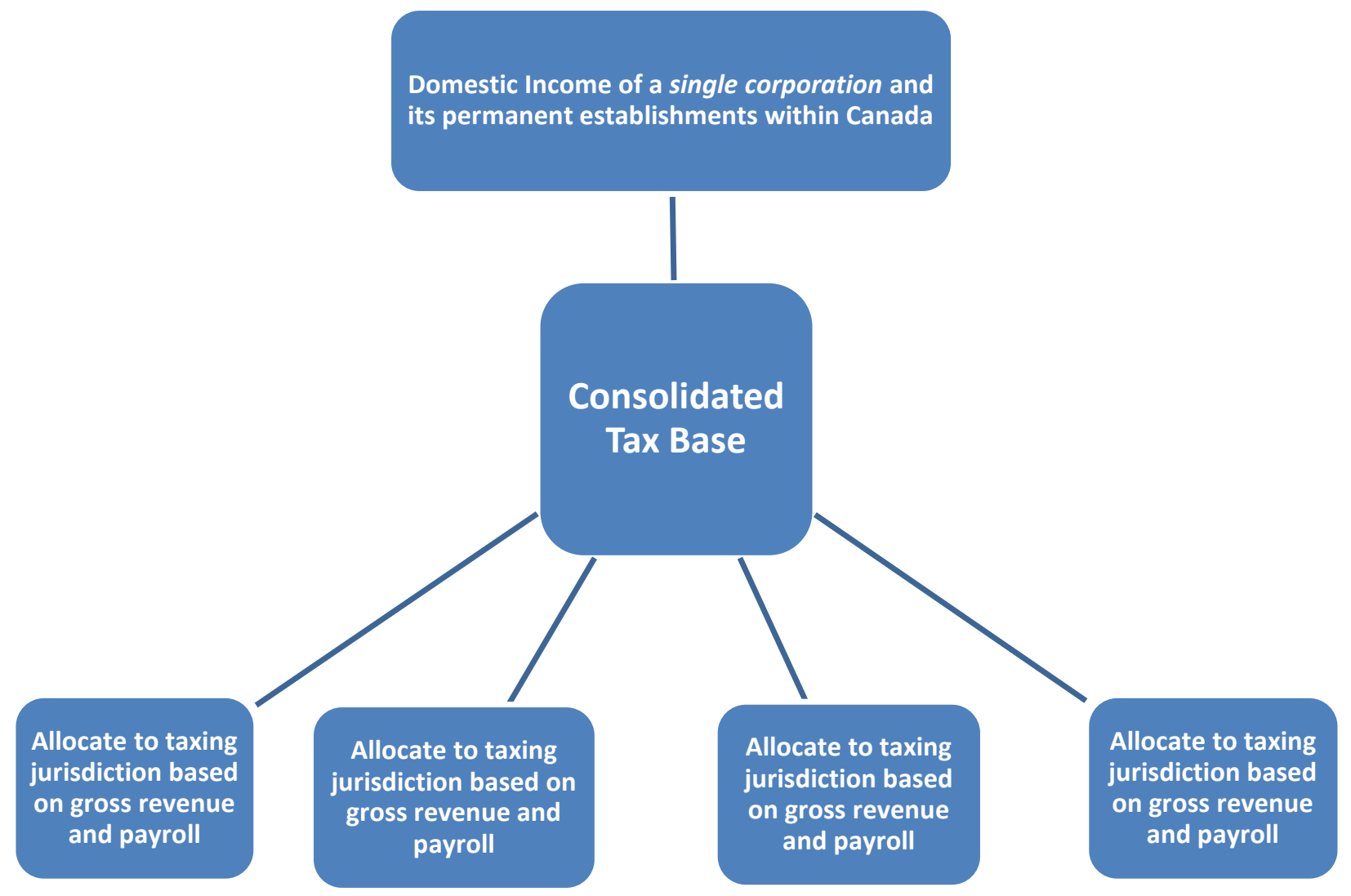

Income Tax regulations; Income Tax Interpretation Bulletin IT-177R2 (Consolidated); Income Tax Guide, Canada Revenue Agency (2012).

33 Similar to the federal 'Small Business Deduction' provided for in Section 125 of the Federal Income Tax Act and Section 6701 of the Regulations to the Income Tax Act.

34 For example, Quebec has one of the most extensive tax incentive structures among the provinces with tax credits in the following sectors: construction, culture, design, electronic commerce, environment, financial sector, food services and retail, forestry, international commerce, investments, job creation, manufacturing, multimedia, natural resources, scientific research and experimental development, technological adaptation, technological innovation and knowledgebased economy, tourism, training, and transportation. See Revenue Quebec, Businesses/Income Tax/Corporation Tax Credits, available at <http://www.revenuquebec.ca/en/entreprise/impot/societes/credits/default.aspx> accessed 19 July 2013.

35 Income Tax Reg. 400(2)(g). 


\subsubsection{Tax base allocation}

With the exception of specific rules for special industries, corporations are required to allocate their taxable income using a two-factor formula: gross revenue, and salaries and wages. Where there is only one factor present, the formula should only contain that factor. The formula is as follows:

$\mathrm{TI}=1 / 2[\mathrm{~A} / \mathrm{B}+\mathrm{C} / \mathrm{D}]^{*}$ total $\mathrm{TI}$

$\mathrm{TI}=$ taxable income for the year for a province

$A=$ allocable gross revenue that is reasonably attributable to a province

$\mathrm{B}=$ allocable gross revenue of the corporation for the year

$\mathrm{C}=$ allocable salaries and wages paid in the year to employees in a province

$\mathrm{D}=$ allocable salaries and wages paid by the corporation in the year.

Gross revenue from the sale of goods is generally allocated on a destination basis. However, if the destination point of shipped goods is outside Canada and the revenue is non-taxable, either by legislation or treaty, the gross revenue is generally first attributed to the PE of the person/company negotiating the sale if available; if not, the revenue is attributed to the province(s) of manufacture and/or production. ${ }^{36}$ Gross revenue from services is attributed to the province in which they are rendered. If the place of rendering is outside Canada where the corporation has no PE, the revenue is attributed to the PE of the person/company negotiating the contract if the person negotiating the contract is attached to the PE in the country. Finally, gross revenue does not include: interest on bonds, debentures, or mortgages, dividends on shares of capital stock, or rents or royalties from property that are not part of the principal business operations. ${ }^{37}$

Wages and salaries also include fees for services that would normally be performed by employees of the corporation and are attributed to the particular PE where the services are rendered. However, fees do not include a commission paid to a person who is not an employee of the corporation. ${ }^{38}$

Along with the general two-factor formula which is used uniformly throughout the provinces, there are nine different formulae applied to certain industries (see Table 2 below). Upon agreement with the provincial tax authority, corporations with multiple business lines may also divide taxable income according to the applicable formulae for each type of business.

\section{Table 2 Special allocation formula rules in Canada}

\begin{tabular}{|l|l||}
\hline SPECIAL ALLOCATION FORMULA RULES IN CANADA \\
\hline \hline Industry sector & Formula \\
\hline \hline Insurance corporations & $\begin{array}{l}\text { Aggregate of net premiums on property }+ \text { net premiums from contracts with residents in a } \\
\text { province/total }\end{array}$ \\
\hline \hline Chartered banks & $1 / 3$ (salaries and wages in a province/total $+2 \times$ loans and deposits in a province/total) \\
\hline Trust and loan corporations & Gross revenue in a province/total \\
\hline Railway corporations & $1 / 2$ (equated track miles in a province/total + gross ton miles in a province/total) \\
\hline
\end{tabular}




\begin{tabular}{|c|c|}
\hline Airline corporations & $\begin{array}{l}1 / 4 \text { (capital cost of all fixed assets, except aircraft in a province/total }+3 \times \text { revenue plane miles } \\
\text { (weighted by take-off weight) flown by its aircraft in the province/total) }\end{array}$ \\
\hline Grain elevator operators & $\mid 1 / 2$ (number of bushels of grain received in a province/total + salaries and wages in a province/total) \\
\hline Bus and truck operators & $\begin{array}{l}1 / 2 \text { (number of kilometres driven by the corporation's vehicles in a province/total + salaries and } \\
\text { wages in a province/total) }\end{array}$ \\
\hline Ship operators & $\begin{array}{l}\text { Aggregate of port-of-call-tonnage in a province/total; if its taxable income for the year exceeds its } \\
\text { allocable income for the year, that proportion of the excess that the aggregate of the salaries and } \\
\text { wages paid in a province/total }\end{array}$ \\
\hline Pipeline operators & $1 / 2$ (number of miles of pipeline in a province/total + salaries and wages in a province/total) \\
\hline Divided businesses & $\begin{array}{l}\text { Can be split according to special formulae and residual to general allocation rules in regulation } 402 \\
\text { by agreement }\end{array}$ \\
\hline
\end{tabular}

\subsubsection{Administration and reporting}

On the annual return, taxpayers with PEs in more than one province or territory must report amounts for each province or territory in which they had a PE in the tax year on the same income tax return. This rule also applies to corporations with PEs in Quebec or Alberta, even though these provinces administer their own taxes and require separate CIT returns. Nonresident corporations doing business within Canada must also file a return, but are only required to report and include income earned within Canada, that is, on a water's edge basis. ${ }^{39}$ Where a corporation has a PE in a province(s) in a year, 10 per cent of its taxable income earned in the year in that province(s) may be deducted from its federal taxable income. ${ }^{40}$

\subsubsection{Conclusion}

The Canadian provincial CIT system is distinctive in its uniformity relative to other jurisdictions following a unitary approach. Although provinces apply divergent tax rates and credits to the tax base, the tax base before these divergences is harmonised: it is determined from the federal definition of income and the same set of general and special allocation formulae are used by all provinces. The weakness of the system, however, is the lack of consolidation of income from corporate affiliates. Because firms are not consolidated beyond the legal corporate entity, each corporation, which may be part of a larger corporate group, operates a separate accounting system for determining corporate taxable income. Consequently, a study has found that this separation, coupled with a corporate tax rate range of 10-16 per cent, provides an incentive for multijurisdictional firms to shift income, primarily through borrowing and lending among affiliates incorporated in different provinces (Mintz and Smart 2004).

Consolidation of affiliates, either based on an ownership test or through a facts and circumstances analysis of the level of economic integration, would avoid the incentive to shift income through related party transactions. Since 1985, and more recently in 2010 , the federal government of Canada has led consultations with stakeholders to consider proposals for tax base consolidation, including a loss transfer system for affiliated companies (Department of Finance Canada 1985, 2010). However, little compromise has been reached between corporate taxpayers and provinces. Generally, corporations favour broad consolidation of profits and losses only after separate entity accounting, while provinces view this form of consolidation as a potentially significant erosion of the provincial tax base and have requested further research on revenue impacts (Richardson and Smart 2013; PriceWaterhouseCoopers 2011; Ontario Ministry of Finance 2011).

\footnotetext{
$39 \quad$ Income Tax Reg. 413.

$40 \quad$ Income Tax Act, Sec. 124(1).
} 


\subsection{Corporate income apportionment in the European Union under the proposed Common Corporate Consolidated Tax Base (CCCTB) ${ }^{41}$}

\subsubsection{Political overview}

The EU is a political and economic community comprised of twenty-eight Member States (MS) and a total population of over 500 million. The CCCTB proposal, currently under evaluation in the EU, harmonises, consolidates and apportions the taxable income of corporate groups operating within the EU. The stated goal of the proposal is to eliminate 'obstacles and distortions [which] impede the proper functioning of the internal market' 42 by establishing common corporate tax rules to lessen 'over-taxation and double taxation' and 'heavy administrative burdens and high tax compliance costs'. ${ }^{43}$

A common market built on the four freedoms of the movement of goods, persons, services and capital was the main aim of the original European Economic Community Treaty signed in Rome in 1958 (now the Treaty on the Functioning of the European Union (TFEU)), and remained central with the establishment of the European Union in 1993 through the Treaty on the European Union (TEU). Although direct taxation has always remained a matter for national states, the EU has the competence to adopt measures for harmonisation of laws aimed at the establishment of the internal market through an 'ordinary legislative procedure' which may include voting by a weighted majority of the $\mathrm{MS},{ }^{44}$ but fiscal provisions still require unanimous agreement to be binding on all MS. ${ }^{45}$

In the first thirty years, therefore, tax harmonisation unsurprisingly was confined to sales taxes (VAT). Although some ambitious blueprints were drawn up, such as the plans of the Neumark Commission in 1962 for a harmonised company tax system based on imputation, and draft proposals produced by the Commission in 1988 for harmonisation of the company tax base (which was never presented to the MS), the only measure relating to direct taxation was a Directive of $1977^{46}$ providing for mutual assistance between national tax authorities. The new phase inaugurated by the Single Market programme from 1988 saw some initial movement towards direct tax harmonisation, with the adoption of three measures to improve tax treatment of cross-border business: a Directive dealing with taxation of gains and losses in the context of cross-border mergers and acquisitions; another exempting from withholding tax dividends paid by subsidiaries to parent companies; and an Arbitration Convention for resolving double-taxation disputes. However, none of the recommendations in the Ruding Committee report of 1992 were acted upon (Commission of the European Communities 1992; Radaelli 1997).

From 1997 a new approach was adopted, focusing on company taxation and emphasising in particular: (i) tax diversity as an obstacle to the Single Market, and (ii) unfair tax competition, with the Commission working more closely in conjunction with the Council. ${ }^{47} \mathrm{An}$ intergovernmental group was set up in March 1997, operating within the framework of the

\footnotetext{
41 Special thanks to loanna Mitrogianni of the European Commission, Unit on Corporate Tax Initiatives, and Sol Picciotto, Professor Emeritus, Lancaster University, for input and helpful comments on this section.

42 European Commission, Proposal for a Council Directive on a Common Consolidated Corporate Tax Base (CCCTB), COM(2011)121 final - 2011/0058 (CNS) [hereinafter 'Directive'], Explanatory Memorandum.

Explanatory Memorandum to the Directive.

Art. 114, 294, TFEU

In some circumstances a special procedure may be available for adoption of legislation by a smaller group of states and binding only on them; this has been used for the proposed Financial Transactions Tax.

46 77/799/EEC. Replaced by Council Directive 2011/16/EU, supplemented by a Regulation laying down detailed rules adopted by the Commission in December 2012. In June 2013 the Commission proposed extending the automatic exchange of information between EU tax administrations, as part of the intensified fight against tax evasion.

47 See the Commission Communication 'A package to tackle harmful tax competition in the European Union' of 5 November 1997 (COM(1997)564 final); confirmed with some changes by the Ecofin Council on 1 December 1997 (O.J. 1998, C2/1).
} 
Council and chaired by the Commission, to work on a confidential basis. ${ }^{48}$ The main task of this group has been the development and application of a Code of Conduct for Business Taxation. This aims to deal with 'potentially harmful tax measures' and covers any business tax measures which may significantly affect the location of business activity within the EU, including employee taxes which may have such an effect. Such measures are considered potentially harmful if they provide for a significantly lower effective rate of taxation (whether in the nominal tax rate or definition of the tax base), and they are to be evaluated in the light of five factors:

(i) benefits given to non-residents or transactions with non-residents;

(ii) benefits 'ring-fenced' so that they do not affect the purely domestic market or tax base;

(iii) benefits available without there being any 'real economic activity';

(iv) taxation of MNEs which departs from 'internationally accepted principles' especially those agreed in the Organisation for Economic Cooperation and Development (OECD); and

(v) measures which lack transparency, including relaxation of formal legal rules by nontransparent administrative decisions.

The Code expected the MS to identify all such measures and to phase them out, if possible within two years. This undertaking was backed up by a right for other MS to seek information and discuss and comment on any measures appearing to fall within the Code, through a review process coordinated by the Commission and taking place in the Code Group. A report submitted in November 1999 was authorised to be published by the Council without endorsement in February 2000. It provided a comprehensive evaluation of 271 measures listed by the Commission as potentially harmful, on the basis of information from MS, of which sixty-six were evaluated as being harmful. The evaluations were made by 'consensus', which meant that where unanimity could not be reached individual states could register their reservations. The Code Group continued its work, focusing mainly on the methods and timetable for amending or phasing out the harmful measures.

A notable feature of the Code is that it has also been applied to MS-dependent and associated territories, many of which are classified as tax havens (notably the Channel Islands, Gibraltar, the Isle of Man and the British Virgin Islands), and in negotiations on accession with candidate countries. A number of measures have been identified as harmful from both these groups of countries, and the Code Group has continued monitoring standstill and rollback of these measures. The Code Group has also had the responsibility of negotiating with third countries, such as Switzerland, on their harmful tax practices. In recent years, the Code Group has worked on issues including transparency and exchange of information relating to transfer pricing (TP), inbound and outbound profit transfers, treatment of hybrid entities and profit participating loans, and patent boxes. ${ }^{49}$

Although the Code is voluntary, it is backed by some powers of legal compulsion under the treaty's competition rules governing state aid. The Council's agreement on the Code in 1998 was complemented by a commitment from the Commission to use its treaty powers on state

\footnotetext{
Council Conclusions of 9 March 1998, OJ C 99/1, 1 April 1998.

See Report to the Council of the Code of Conduct Group (Business Taxation), Doc 10242/13 FISC 112 of 13 June 2013, final revised version Doc 11465/13 FISC 134 of 21 June 2013. A later report (16656/13 FISC 226), not yet released to the public, was considered by the Council meeting of 10 December 2013, which invited the Group inter alia to continue its work on hybrid entity and PE mismatches, and consider all patent boxes in the EU, in the context of international developments including the OECD's Base Erosion and Profit Shifting (BEPS) project, and to analyse the third criterion of the Code ('whether advantages are granted even without any real economic activity and substantial economic presence within the Member State offering such tax advantages') and report by June 2014. It also invited the Commission to try to conclude speedily its discussions with Switzerland regarding the Code, which have been under way for several years.
} 
aid to take action against fiscal regimes which entail competition-distorting subsidies, based on a case-by-case examination of the arrangements in MS for direct business taxation. ${ }^{50}$ The criteria to be applied were that the measure should:

(i) confer on recipients an advantage relieving them of charges which would 'normally' fall on their budgets, including a reduction of the tax base (e.g. special depreciation allowances), total or partial reduction of tax due, or deferment or cancellation of tax debt;

(ii) involve state resources (including loss of revenue);

(iii) affect competition and trade between MS; and

(iv) be specific or selective in that it 'favours certain undertakings or the production of certain goods' and not be justified by 'the nature or general scheme of the system'.

This produced some results, in the form of an agreement with Ireland to phase out its low 10 per cent corporate tax rate for the manufacturing sector by $2002,{ }^{51}$ although this was in the context of the Irish government's policy to reduce the general rate of corporation tax to 12.5 per cent by 2003. Indeed, even before that date the effective rate of corporation tax in Ireland was 10 per cent for most companies, significantly out of line with the European average of almost 30 per cent. The Commission used its state aid powers as a threat to prod the MS to achieve progress in the discussions under the Code. It initiated proceedings under its state aid powers, in respect of Gibraltar's exempt companies and qualifying companies legislation, Finland's scheme for Ăland islands captive insurance companies, Spain's scheme for coordination centres in Vizcaya, and Italy's Financial Services and Insurance Centre in Trieste, all of which had been listed as potentially harmful under the Code in the 1999 Report. In October 2002 it initiated fresh proceedings in respect of Gibraltar's proposed corporate tax reform, which was intended as a rollback measure to bring its tax regime into line with the Code. In the context of renewed concern about corporate tax avoidance and the initiation in July 2012 of the OECD's project on Base Erosion and Profit Shifting (BEPS), in September 2013 the Commission was reported to have sent letters to Ireland, Luxembourg and the Netherlands to justify the validity under EU state aid rules of some of their advance rulings. ${ }^{52}$

The work of the Code of Conduct Group, and the Commission's activation of its state aid powers, provided a lever which persuaded the MS to allow the Commission to begin technical work on corporate tax harmonisation. In 2001, the Commission announced a company tax study 'to pursue more comprehensive, politically ambitious solutions such as providing companies with the option for a single set of rules on the corporate tax base for their EU-wide activities'. ${ }^{3}$ By 2004, a working group with six sub-groups was established to devise such rules, concluding its work by 2008. In the context of the Euro crisis and calls for closer fiscal coordination, in March 2011 the Commission adopted a proposal for a CCCTB, and submitted this to the inter-institutional decision-making procedure. ${ }^{54}$ It was approved with some proposed amendments by a large majority in the European Parliament, and the

50 'Commission notice on the application of the state aid rules to measures relating to direct business taxation, Commission of the European Communities', OJ 98/C 384/03 of 10 December 1998.

51 'Proposals for appropriate measures under article 93(1) of the EC Treaty concerning Irish corporation tax (ICT)', OJ C395/19, 18 December 1998. The ICT was introduced in 1980 to replace the scheme which gave relief for manufacturing companies from corporation tax on profits earned from export sales, and since it applied to the entire manufacturing sector was not considered state aid, even when extended in 1990 up to 2010.

52 'Looking into sweetheart tax deals', Financial Times, 11 September 2013. The Code of Conduct Group has examined the issue of administrative rulings, resulting apparently only in agreement on improved exchange of information: see Report of Code of Conduct Group to Council of 7 December 2010 Doc. 16766/10 FISC 139, paras 18-21.

$53 \quad \operatorname{COM}(2001) 260$ final, p.16; See COM(2001) 582 final.

$54 \quad$ The European Commission has the right of legislative initiative to protect the common interest of the Union (Art.17, TEU). The College of Commissioners may adopt a proposal from the European Commission (EC) through a majority vote (Art. 250, TFEU). Once adopted, the proposal is put to the Council of Ministers for adoption (Art. 115, TFEU). 
Economic and Social Committee gave its opinion. ${ }^{55}$ Since then, it has been under technical examination by the Council; three different presidencies have produced compromise proposals with significant revisions, and technical work is ongoing, now focusing on the common tax base. ${ }^{56}$ The adoption of the CCCTB Directive requires unanimous approval of the MS in the Council of Ministers. ${ }^{57}$ However, it is possible for a smaller group of MS to proceed on their own through an exceptional procedure for 'enhanced cooperation'. Upon adoption, the Directive must be implemented into the national tax systems of each MS with supplementary regulations. ${ }^{58}$

The CCCTB Directive was developed under Article 115 of the TFEU as a measure aiming to 'directly affect the establishment or functioning of the internal market'. ${ }^{59}$ The EU and the MS have shared competence in regard to the internal market. ${ }^{60}$ The EU may exercise its competence only to the extent that the MS have not exercised their competence. ${ }^{61}$ Thus, under the principle of subsidiarity, the EU should act 'only if and in so far as the objectives of the proposed action cannot be sufficiently achieved by the Member States'. ${ }^{62}$ Under the principle of proportionality, 'the content and form of Union action should not exceed what is necessary to achieve the objectives of the Treaties'. ${ }^{63}$ Hence, the Directive deals only with the computation and apportionment of the tax base and not the determination of the tax rate or tax liability. ${ }^{64}$ Moreover, national tax authorities may administer parallel systems, or they may choose to align national rules with the CCCTB.

\subsubsection{Tax base harmonisation}

The proposal developed by the Commission is optional for firms: eligible companies may join the taxation system prescribed by the CCCTB Directive if they meet the requirements of Annexes I and II. ${ }^{65}$ Generally, eligible companies must either: (i) be incorporated in an MS (eligible company forms are listed in Annex I) and be subject to company taxation in one or more MS; ${ }^{66}$ or (ii) be a company incorporated in a third jurisdiction with a similar company

55 European Parliament legislative resolution of 19 April 2012 on the proposal for a Council directive on a Common Consolidated Corporate Tax Base (CCCTB), P7_TA(2012)0135 [hereinafter European Parliament Resolution]; Opinion of the European Economic and Social Committee on the 'Proposal for a Council directive on a Common Consolidated Corporate Tax Base (CCCTB)', 2012/C 24/12 (26 October 2011).

56 See Council of the European Union, 'Compromise Proposal, Proposal for a Council Directive on a Common Consolidated Corporate Tax Base (CCCTB)', 2011/0058 (CNS): 8790/12 (16 April 2012) [hereinafter Danish Compromise proposal]; 9180/13 (2 May 2013 [sic]) [hereinafter Irish Compromise proposal]; 14768/13 (14 October 2013) [hereinafter Lithuanian Compromise proposal]; see also Council of the European Union, Presidency Synthesis Report on the bilateral discussions, Proposal for a Council Directive on a Common Consolidated Corporate Tax Base (CCCTB), 2011/0058 (CNS), 7830/13 (27 March 2013).

$57 \quad$ Art. 115, TFEU.

58 'A directive shall be binding, as to the result to be achieved, upon each Member State to which it is addressed, but shall leave to the national authorities the choice of form and methods' (Art. 288, TFEU).

59 'Without prejudice to Article 114, the Council shall, acting unanimously in accordance with a special legislative procedure and after consulting the European Parliament and the Economic and Social Committee, issue directives for the approximation of such laws, regulations or administrative provisions of the Member States as directly affect the establishment or functioning of the internal market' (Art. 115, TFEU).

$60 \quad$ Art. 4(2)(a), TFEU. See also Vascega and van Thiel (2012).

$61 \quad$ Art. 2(2), TFEU.

62 Art. 5(1)-(3), TEU. 'The rules set out in this proposal, such as the relief for cross-border losses and tax-free group restructurings, would be ineffective and likely to create distortion in the market, notably double taxation or non-taxation, if each Member State applied its own system. Neither would disparate national rules for the division of profits improve the current - already complex - process of allocating business profits amongst associated enterprises. The nature of the subject requires a common approach'. Directive, Explanatory Memorandum, pp. 9-10.

63 Art. 5(4), TEU. The Commission proposal for the CCCTB provides for an optional system, allowing groups of companies to opt in on an all-in or all-out basis, however, the European Parliament has amended the proposal to make the CCCTB mandatory for all companies, except small- and medium-sized enterprises. See European Parliament Resolution, Amend. 14; Directive, Explanatory Memorandum, p. 9-10.

64 See Directive, Art. 103.

65 Directive, Art. 2.

$66 \quad$ Eligible company taxes are listed in Annex II. These lists may be updated through committee procedure, also known as comitology. See EU Reg. No 182/2011 and CCCTB/WP062 for a technical explanation of the comitology procedure. 
form and which is subject to company taxation in one or more MS through its PE there. The eligible company is deemed a 'taxpayer'. If a non-resident taxpayer has a PE, the state of establishment has the right to tax the income from business activities attributed to the PE. A $P E$ is created when a taxpayer has a fixed place of business in a state other than the state in which its central management and control is located. ${ }^{67}$

The CCCTB provides for a high degree of tax base harmonisation: it includes definitions of profit, loss, revenue, expenses and other deductible items, along with a framework for depreciation. The tax base under the CCCTB is defined as revenue less exempt revenue, deductible expenses and other deductible items. ${ }^{68}$ Revenue includes proceeds of sales and any other transactions, net of VAT and any other tax and duties. ${ }^{69}$ Exempt revenue includes subsidies linked to the acquisition, construction or improvement of depreciable fixed assets; ${ }^{70}$ gains from the sale of depreciable fixed assets; received profit distributions; gains from the sale of shares; and income from PEs in third countries. ${ }^{71}$ Deductible expenses include all costs of sales and expenses net of VAT; research and development costs; costs incurred raising debt or equity for the business; charitable and monetary gifts to approved bodies up to 0.5 per cent of revenue ${ }^{72}$ and deductions for depreciation of fixed assets. ${ }^{73}$ Article 14 also provides a list of non-deductible items. ${ }^{74}$ The Irish Compromise proposal has also added a loss limitation rule, which limits the deduction for borrowing costs to the amount of interest received or other taxable revenue from financial assets; any excess borrowing costs are only deductible up to a maximum threshold, and total deductions for borrowing costs must not exceed 60 per cent of the tax base..$^{75}$ In any case, borrowing costs less than one million euros per single taxpayer may be deducted..$^{76}$ Loss is defined as an excess of deductible expenses and other deductible items over revenue in a tax year. ${ }^{77}$ Losses may be carried forward indefinitely and deducted against taxable income in subsequent tax years on a 'first in, first out' basis. ${ }^{78}$ There is no corollary carry-back provision.

67 A fixed place of business may include: a place of management; a branch; an office; a factory; a workshop; a mine, an oil or gas well, a quarry or any other place of extraction of natural resources. To be considered a fixed place of business, a building site or construction or installation project must last more than twelve months. Use of facilities, or maintenance of a stock of goods solely for the purpose of storage, display or delivery or processing by another person, or the maintenance of a fixed place of business solely for the purpose of purchasing goods or merchandise or of collecting information, or any other activity of a preparatory or auxiliary character, will not create a PE. If an agent acts on behalf of a taxpayer and has, and habitually exercises, authority to conclude contracts in the name of the taxpayer, a PE is created. Merely carrying on business through a broker, general commission agent or any other agent of an independent status, in the ordinary course of their business, though, does not create a PE. Controlling or being controlled by a nonresident taxpayer will not in itself created a PE. Directive, Art. 5.

68 Directive, Art. 10.

69 Revenue includes that of a monetary or non-monetary nature, which may consist of proceeds from disposal of assets and rights, interest, dividends and other profit distributions, proceeds of liquidation, royalties, subsidies and grants, gifts received, compensation and ex-gratia payments, non-monetary gifts made by a taxpayer, but not including equity raised or debt repaid to it. Directive, Art. 4(8).

70 The subsidies are deducted against the depreciable base. Directive, Art. 33.

Directive, Art. 11.

Directive, Art. 12.

Directive, Art. 13. Long-life tangible and intangible assets are depreciated individually while others are depreciated in pools of assets. For example, buildings are depreciable over 40 years, other long-life assets over 15 years, and asset pools are generally depreciated annually at $25 \%$ of the depreciable base. See Directive Art. $32-42$ for specific depreciation provisions.

74 Non-deductible items include: profit distributions; repayment of equity or debt; $50 \%$ of entertainment costs; transfer of retained earnings to equity reserves; corporate tax; bribes; fines and penalties to a government; costs above $5 \%$ incurred for deriving exempt revenue; monetary gifts to persons and entities other than approved charitable bodies; except non-depreciable expenses and depreciable fixed assets and research and development costs, other costs related to the acquisition, construction or improvement of fixed assets; and certain taxes which raise a material amount of revenue (listed in Annex III) with the exception of excise duties. Directive, Art. 14.

See Irish Compromise proposal, 13. Excess unrelieved borrowing costs may be relieved in subsequent years.

See Irish Compromise proposal, 13.

Directive, Art. 4(10).

Losses incurred before opting into the CССTB and losses incurred under the CCCTB upon leaving the system are deductible against future taxable income under the rules of the respective national tax legislation. Directive, Art. 43, 48, $53,57(2)$. 
Tax incentives and rates are not regulated by the Directive. ${ }^{79}$ However, it is important to note that under the TFEU state aid is limited in the area of economic development to areas with 'abnormally low' living standards and regulated by the Commission. ${ }^{80}$

\subsubsection{Tax base consolidation}

When opting into the CCCTB, resident taxpayers must form a group comprised of all its PEs resident in an EU MS. Qualifying subsidiaries resident in an EU MS and their PEs resident in an EU MS must also be included in the group. For resident subsidiaries of a foreign parent company, the subsidiaries and their resident PEs must also form a group. ${ }^{81} \mathrm{~A}$ qualifying subsidiary includes immediate and lower-tier subsidiaries in which the parent has a right to exercise more that 50 per cent of the voting rights, and an ownership right to more than 75 per cent of the company's capital or more than 75 per cent of the rights giving entitlement to profit. ${ }^{82}$ The tax bases of all group members must be consolidated. ${ }^{83}$ All intra-group transactions are ignored for tax purposes and no withholding or other taxation at source is to be assessed on intra-group transactions. ${ }^{84}$ (See Diagram 5.)

\section{Diagram 5 CCCTB tax base definition, consolidation, allocation and apportionment}

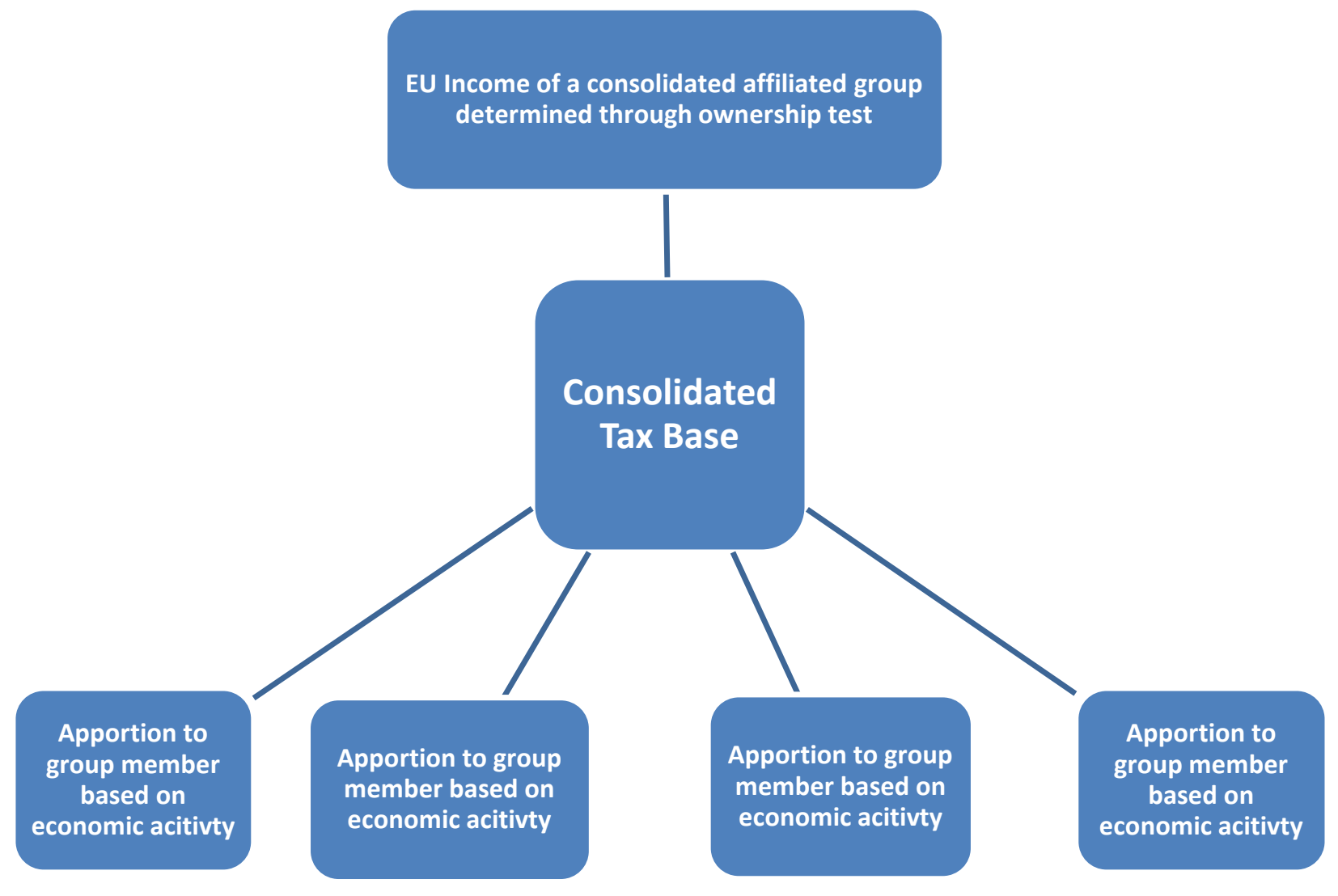

Directive, Art. 103 provides that the tax liability is determined through application of the respective national tax rate to the base as defined under the CCCTB.

80 TFEU, Art. 107(3)(a), (c). See the criteria for fiscal state aid discussed above, and for further discussion on state aid regulation, see Wishlade (2012).

Directive, Art. 55.

Directive, Art. 54(1).

Directive, Art. 57.

Directive, Art. 59, 60. 


\subsubsection{Tax base apportionment}

The tax base is apportioned between group members (and indirectly to the MS) on the basis of a formula of three factors: capital, labour (comprised of payroll and employees) and sales. ${ }^{85}$ In other words, the share of the tax base apportioned to a group member equals the consolidated tax base multiplied by a fraction of the group member's share of sales, labour and assets over that of the entire group. (The factor weighting was modified by the European Parliament, which assigned a 45 per cent weighting to both the labour and asset factors and 10 per cent to the sales factor ${ }^{86}$ ) The formula, as provided by the CCCTB Directive, is as follows:

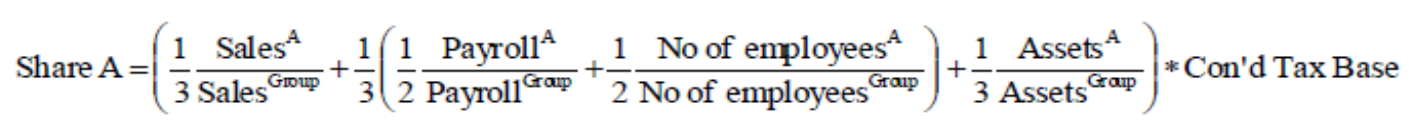

The labour factor includes payroll and employees (at equal weights). Payroll is comprised of salaries, wages, bonuses and all other employee compensation, including related pension and social security costs borne by the employer, and should be equal to amounts deducted by the taxpayer within the year. ${ }^{87}$ Additionally, the definition of employee is determined by the national law in which the employment is exercised..$^{88}$

The asset factor includes the average value of all fixed tangible assets owned, rented or leased. ${ }^{89}$ Land and all other non-depreciable fixed tangible assets are valued at original cost; depreciable assets at average value throughout the year; and rented or leased assets are valued at eight times the annual rental rate..$^{90}$ The asset factor is also adjusted upon entry and exit for self-generated intangibles. For this purpose the Directive uses a proxy for the value of the intangible, which consists of research and development, marketing and advertising costs incurred over a number of years before entry and/or exit. ${ }^{91}$ An asset is depreciated by its economic owner and only by its legal owner in cases where the economic owner cannot be identified. ${ }^{92}$ Intangibles, financial assets and current assets, such as inventory, are not included in the asset factor.

The sales factor includes the proceeds of all sales of goods and supplies of services after discounts and returns, excluding VAT and other taxes and duties. ${ }^{93}$ Sales are deemed at the destination point, which is defined as 'where dispatch or transport of the goods to the person acquiring them ends'. ${ }^{94}$ There is a throwback rule to last identifiable location of the goods or carrying out of service for destination points with no group member registered there (either an MS or a third jurisdiction). Additionally, sales are subject to the throw-out rule when there is no group member in the MS or the third jurisdiction of last identifiable location. When thrown out, the sales are included in the formula and apportioned to the group members in

\footnotetext{
85 Directive, Art. 86.

$86 \quad$ European Parliament Resolution, Amend. 16.

87 An employee is attributed to the group member from which (s)he receives remuneration or the group member which exercises control and responsibility of the physical employment of the employee (for at least 3 months and for at least $5 \%$ of the workforce) if there is a variance. Furthermore, indirect employment is included: an employee is attributed to a group member even if not directly employed by that group member where the employee performs tasks similar to those of employees. Directive, Art. 89.

Directive, Art. 90.

Directive, Art. 92(1)

Directive, Art. 94

Directive, Art. 68, 92(2).

If there is a variance between the economic owner and the group member which effectively uses the asset, it is to be allocated to the group member (but only up to $5 \%$ of the value of the total fixed assets of that group member). Directive, Art. 93.

93 Exempt revenue, interest, dividends, royalties and proceeds from the disposal of fixed assets shall not be included in the sales factor, unless earned in the ordinary course of trade or business. Intra-group sales of goods and supplies of services are excluded. Directive, Art. 95(2).

$94 \quad$ Directive, Art. 96.
} 
proportion to the two other factors. ${ }^{95}$ Services are deemed to take place where they are physically carried out; there is no rule for electronically performed services. ${ }^{96}$

\section{Special rules}

The CCCTB Directive has a safeguard clause which allows for alternative apportionment methods in cases where the outcome of the apportionment does not fairly reflect business activity ${ }^{97}$ In addition, for certain industries, there are adjustments which may be applied to the factors of the general formula. ${ }^{98}$ (See Table 3.)

\section{Table 3 CССTВ special apportionment formula rules for selected industries}

\begin{tabular}{|l|l|}
\hline \multicolumn{2}{|l|}{ CCCTB special apportionment formula rules for selected industries } \\
\hline Industry & Adjustment of the apportionment factor \\
\hline Financial institutions & $\begin{array}{l}\text { Asset factor includes } 10 \% \text { of the value of financial assets; sales factor includes } \\
10 \% \text { of revenue from interest, fees, commissions and revenue from securities }\end{array}$ \\
\hline Insurance & $\begin{array}{l}\text { Asset factor includes } 10 \% \text { of the value of financial assets; sales factor includes } \\
10 \% \text { of earned premiums net of reinsurance, allocated investment returns } \\
\text { transferred from the non-technical account, other technical revenue net of } \\
\text { reinsurance, and investment revenue, fees and commissions }\end{array}$ \\
\hline Oil and gas & $\begin{array}{l}\text { Sales are attributed to the place of extraction and production; if there is no group } \\
\text { member located in the state of extraction or production, the sales will be } \\
\text { attributed to the group member which carries on the extraction and production }\end{array}$ \\
\hline $\begin{array}{l}\text { Ships or aircraft in international } \\
\text { traffic or the operation of boats } \\
\text { engaged in inland waterway } \\
\text { transport }\end{array}$ & $\begin{array}{l}\text { Revenue, expenses and other deductible items of a group member whose } \\
\text { principal business is the operation of ships or aircraft in international traffic or the } \\
\text { operation of boats engaged in inland waterway transport are not apportioned } \\
\text { according to the general formula but are attributed to that group member }\end{array}$ \\
\hline
\end{tabular}

\section{Anti-abuse provisions}

The CCCTB provides several measures which re-characterise other types of revenue as income to the taxpayer. Under Article 11, revenue from received profit distributions, gains from the sale of shares, and income from PEs in third countries are exempt. However, under Article 73's switch-over clause, when this revenue is generated from entities resident in third country jurisdictions where the tax rate is lower than 40 per cent ${ }^{99}$ of the average EU corporate tax rate or there is a special tax regime which allows for a substantially lower level of tax, the revenue is no longer exempt and is included as income. There are also provisions for transactions between associated enterprises under Article 79. Any benefit accruing to taxpayers due to special conditions between associated enterprises, which would not otherwise exist between independent enterprises, is considered as income to the taxpayer. ${ }^{100}$

The general anti-abuse rule of Article 80 provides that transactions carried out for the sole purpose of avoiding tax, ${ }^{101}$ as opposed to genuine commercial transactions, may be ignored. The Irish Compromise proposal has replaced 'sole' with 'essential' and has substantially strengthened this provision, requiring analysis of the commercial substance of business

\footnotetext{
$95 \quad$ Directive, Art. 96.

$96 \quad$ Directive, Art. 96.

97 Directive, Art. 87.

98 Directive, Art. 98-101.

99 The European Parliament has amended this threshold from $40 \%$ to $70 \%$. See European Parliament Resolution, Amend. 27.

100 Taxpayers are deemed as associated enterprises to PEs in third countries and non-resident taxpayers are deemed as associated enterprises to PEs in MS. Moreover, if a taxpayer participates (directly or indirectly) through $20 \%$ ownership of capital or voting rights or occupies a position of significant influence in the management of an enterprise, the taxpayer and that enterprise are deemed as associated enterprises.

101 The European Parliament replaced the word 'solely' with 'mainly'. See European Parliament Resolution, Amend. 28.
} 
arrangements. ${ }^{102}$ Under Article 81, interest deductions are limited where there is no exchange of information agreement between the EU and the entity resident in a third jurisdiction, ${ }^{103}$ and the interest is paid to an entity resident in that jurisdiction where the tax rate is lower than 40 per cent of the average EU corporate tax rate or there is a special tax regime which allows for a substantially lower level of tax. ${ }^{104}$

Under the controlled foreign company (CFC) rules of Article 82, a taxpayer's taxable income will include the non-distributed income of an entity resident in a third country when all the following conditions are met: the taxpayer by itself, or together with its associated enterprises, holds more than 50 per cent of the voting rights (directly or indirectly), or owns more than 50 per cent of capital, or is entitled to receive more than 50 per cent of the profits of that entity; the tax rate in the third country is lower than 40 per cent ${ }^{105}$ of the average EU corporate tax rate or there is a special tax regime which allows for a substantially lower level of tax; more than 30 per cent of the foreign entity's income is comprised of any of the following categories of income (i.e. mostly passive income): interest; royalties; dividends and income from the disposal of shares; income from movable property; income from immovable property; ${ }^{106}$ or income from insurance, banking and other financial activities. In addition, more than 50 per cent of the income from these categories must come from transactions between the CFC and the taxpayer or its associated enterprise. ${ }^{107}$

\subsubsection{Administration, reporting and dispute resolution}

The competent authority is the authority designated by each MS to administer the Directive. ${ }^{108}$ The principal tax authority is the competent authority located in the state of residence of the principal taxpayer. ${ }^{109}$ On behalf of the group, the principal taxpayer reports and files a single consolidated return to the principal tax authority which must be stored on a central database, accessible by all competent authorities. ${ }^{110}$ Competent authorities are also obligated to respond to requests for cooperation or exchange of information regarding a group member within three months. ${ }^{111}$ Moreover, the competent authority of an MS where the taxpayer is resident or established may request 'all information relevant to the determination of [the taxpayer's] tax liability' ${ }^{\prime 12}$ and jointly conduct audits with the principal tax authority. ${ }^{113}$

In the case of a disagreement between competent authorities, a decision may be challenged before the court of the MS of the principal tax authority within three months. ${ }^{14}$ For taxpayers, administrative and judicial appeals must be lodged in the MS of the principal tax authority

\footnotetext{
102 See Irish Compromise proposal, 36-37.

103 Directive 2011/16/EU.

104 If these conditions are not present, an interest deduction is allowed provided that the amount of interest does not exceed what would be agreed by independent enterprises in any of the following cases: the interest income is included in the tax base according to the controlled foreign companies rules of Article 82; the interest is paid to an entity whose principal class of shares is publicly traded on a recognised stock exchange; or the interest is paid to an entity which is engaged in an active trade or business in its country of residence. The European Parliament has amended this threshold from 40\% to 70\%. See European Parliament Resolution, Amend 29.

106 If the MS of the taxpayer would not have been entitled to tax the income from the immovable property under an agreement concluded with a third country, the immovable property category does not apply to the analysis. In any case, where the resident country of the foreign entity is party to the European Economic Area Agreement and there is an information exchange agreement, these rules do not apply.

Directive, Art. 4(21).

Directive, Art. 4(6), (7), (22).

Directive, Art. 109, 115.

Directive, Art. 120(2).

Directive, Art. 118.

Directive, Art. 122.

Directive, Art. 123.
} 
within sixty days of receipt of the action appealed. ${ }^{115}$ The Commission does not audit or review or otherwise get involved in the tax administration as this is purely an MS competence, except in limited implementation circumstances such as a comitology and delegated acts procedure. ${ }^{116}$

\subsubsection{Conclusion}

At the current stage of development, the proposed CCCTB Directive represents the most comprehensive framework for a unitary taxation approach. Indeed, it is unique in providing a detailed technical proposal for a system of unitary taxation which would operate between sovereign states, although within the institutional framework of the EU. While leaving it to participating MS to set their own tax rates and tax credits (subject to the state aid restrictions under the TFEU), the CCCTB provides for a significant level of tax base harmonisation, and this may be taken further through the continuing technical work being done by the Council. It also provides special rules for associated enterprises and for transparent entities, a set of anti-abuse rules and a switch-over clause for otherwise exempt income from low- or no-tax jurisdictions. ${ }^{117}$ The CCCTB would only apply within the EU and follows a strictly water's edge approach so that, subject to its own CFC provisions, the overlay of double tax agreements would regulate relations with associated enterprises in third jurisdictions.

Considerable technical work has been done and is ongoing, both by the Commission, working with representatives of stakeholders, and during technical scrutiny by MS in the European Council. ${ }^{118}$ The result is a draft proposal with considerable technical sophistication. However, aside from the relatively short period of debate in the European Parliament, it has received very little public or political attention, and political agreement on the proposal is unlikely in the short term.

\subsection{Corporate income apportionment in Switzerland}

\subsubsection{Political overview}

Although a recorded alliance has existed among sovereign states of Switzerland since $1291,{ }^{119}$ the modern federal state was not formed until 1848. With a population of just over eight million, Switzerland is governed through a unique form of direct democracy. ${ }^{120}$ When the confederation was established in 1848, Switzerland became a single judicial and economic union - foreign policy, defence, customs, postage and coinage were centralised and unified, no longer administered separately by the cantons. Although the jurisdiction to levy customs duties was transferred from the cantons to the confederation, the authority to levy income and wealth taxes remained with the cantons. Towards the end of World War I, however, when the confederation introduced stamp taxes to raise revenue, the National

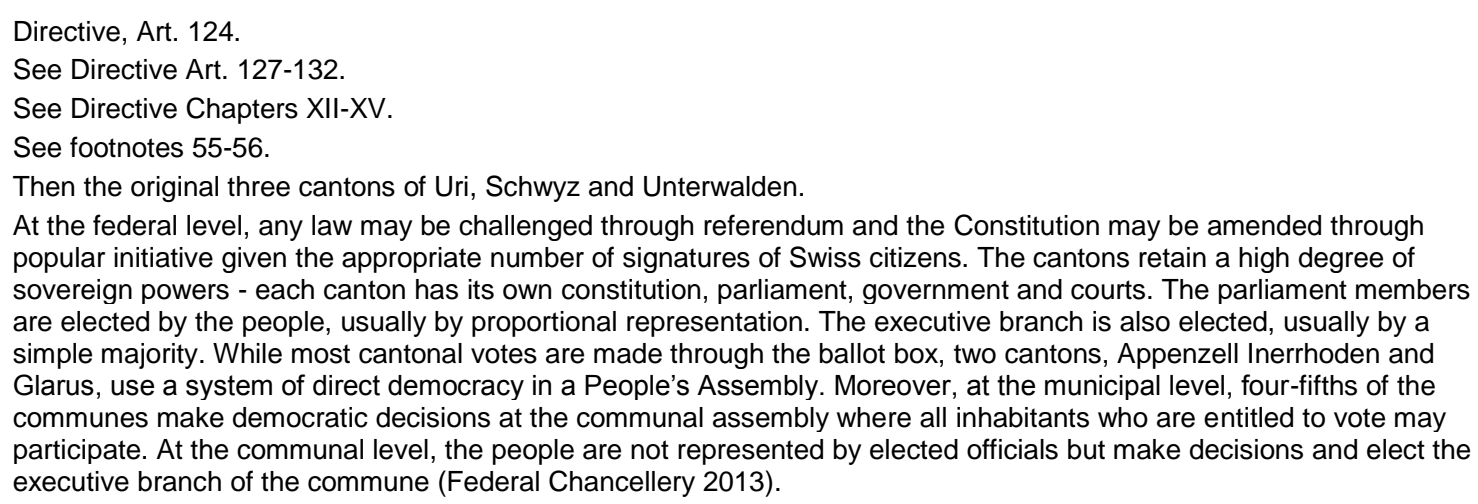
popular initiative given the appropriate number of signatures of Swiss citizens. The cantons retain a high degree of sovereign powers - each canton has its own constitution, parliament, government and courts. The parliament members are elected by the people, usually by proportional representation. The executive branch is also elected, usually by a simple majority. While most cantonal votes are made through the ballot box, two cantons, Appenzell Inerrhoden and Glarus, use a system of direct democracy in a People's Assembly. Moreover, at the municipal level, four-fifths of the communes make democratic decisions at the communal assembly where all inhabitants who are entitled to vote may participate. At the communal level, the people are not represented by elected officials but make decisions and elect the executive branch of the commune (Federal Chancellery 2013). 
Defense Tax (Federal Direct Tax) on income and wealth was also introduced. ${ }^{121}$ Today, this tax, along with VAT, is the most significant tax assessed at the federal level. ${ }^{122}$

While the confederation and the cantons currently have concurrent powers of direct taxation, this right for the confederation expires in the year 2020 and must be renewed by popular vote under Article 196(13) of the Federal Constitution. Under Article 128, the confederation is limited to a maximum rate of tax on corporate income of 8.5 per cent. This tax is assessed and collected by the cantons, and a minimum of 17 per cent of the gross revenue is allocated to the cantons. Cantonal tax rates are assessed either as a proportional tax on net profit or a combined system with two or three graduated rates depending on the return to equity or amount of profit; these rates range from 1.5 per cent to 20 per cent. Thus, the cantons derive much more revenue from CIT than the confederation. ${ }^{123}$

Intercantonal double taxation is prohibited by Article 127 (3) of the Swiss Constitution. Article 127 also provides that the main features of any tax, in particular those liable to pay the tax, the object of the tax and its assessment, are regulated by law, giving authority to the federal government to legislate measures to avoid double taxation among the cantons. The principles of universality, uniformity and ability to pay ${ }^{124}$ are applied to such legislation. The federal Supreme Court of Justice (Swiss Supreme Court) has developed case law to determine how this prohibition against double taxation is to be implemented. ${ }^{125}$

Article 129 of the Federal Constitution allows the confederation to legislate principles of harmonisation of the direct taxes imposed by the confederation, the cantons and the communes. Harmonisation extends to the subject of tax liability, the object of the tax and the tax period, procedural law and the law relating to tax offences. Matters excluded from harmonisation include tax brackets, tax rates, and tax allowances, i.e. exempted amounts, depreciation schedules, as well as tax credits against the base. ${ }^{126}$ A Federal Law on Harmonisation of the Direct Taxes of the Cantons and Municipalities (Tax Harmonisation Act) was enacted in 1990, came into force 1 January 1993, and gave cantons until 1 January 2001 to implement their own harmonisation laws. The Harmonisation Law may be amended on an ongoing basis to reflect changes in the decisions of the Swiss Supreme Court. These amendments provide a fixed period of time for adoption by the cantons and communes. Supporting regulations (Verordnung) provide further details of the laws, and guidance notes (Kreischreiben) are issued at both the federal and cantonal level in the form of circulars. The Swiss Tax Conference, a coordinated body of federal and cantonal tax administrators

The Federal Direct Tax (levied on income of individuals and on profits of legal entities) is regulated by the Federal Law on Direct Federal Tax, although it is administered by cantonal tax authorities along with the cantonal and commune tax. Under Articles 130-134 of the Federal Constitution, the confederation claims exclusive jurisdiction over VAT, special consumption taxes on beer and distilled spirits, tobacco, petroleum and natural gas, and automobiles, stamp duties, withholding tax, and customs duties. Federal Constitution of the Swiss Federation of 18 April 1999. See also Daly and Weiner (1993); Mayer (2009); Simonek (2012); Federal Department of Finance (2013).

There are three levels of taxation in Switzerland: assessment by the Swiss confederation; by the 26 cantons; and by the 2,408 communes. The cantonal constitutions define the types of taxes the communes are entitled to levy. Commune tax is a percentage of cantonal tax, and, along with cantonal tax, is regulated by cantonal law and administered by cantonal tax authorities. In some communes, communal tax is collected separately. Initially, the cantons levied a tax primarily on net wealth and earned income, but by 1970 all cantons principally taxed earned income. In nearly all cantons, corporations are subject to CIT as well as tax on equity (paid-up capital and reserves). See Art. 30 para. 2, Tax Harmonisation Law.

Besteurung nach der wirtschaftlichen leistungsfähigkeit, meaning that the tax must be proportionate to the ability to pay, so that those who earn more or own more should pay more tax. See Art. 127 of the Swiss Constitution.

For example, Court decisions interpret the prohibition against double taxation to include virtual double taxation and have also strengthened the prohibition of less favourable treatment. Virtual double taxation can occur where a canton taxes income or gain that should be allocated to another canton but that other canton for some reason does not tax such income or gains.

126 For example, Article 23(3) of the Federal Tax Harmonisation Act allows the establishment of tax concessions for new businesses for up to 10 years. Not surprisingly, all cantonal tax legislation provides some level of relief for newlyincorporated businesses. See, e.g., Kanton Zurich Finanzdirektion Steueramt, Canton of Zurich as business location, available at <http://www.steueramt.zh.ch/internet/finanzdirektion/ksta/en/business location.html>. 
established in 1919, discusses and proposes model guidance notes which may be adopted by the cantonal authorities.

\subsubsection{Tax base harmonisation}

Taxation of the income from intercantonal business activities of a corporation is based on tax domicile. A corporation's business activities or presence may give rise to a primary tax domicile, a secondary tax domicile, or a specific tax domicile. The only exception to this categorisation is for corporations with no link other than registration, so called 'letter box' tax domicile. In this case, the actual place of management is deemed to establish the primary tax domicile, while the canton exercising this taxing jurisdiction bears the burden of proof. Income of intercantonal enterprises is apportioned between the primary tax domicile and the secondary tax domicile(s), while income from a specific tax domicile is allocated to that specific domiciliary jurisdiction. Primary tax domiciles are, in most cases, the place of corporate registration, while secondary tax domiciles are classified as PEs of the corporation. ${ }^{127}$ Specific tax domicile arises through ownership of real property in a jurisdiction which is not the primary tax domicile.

The Federal Tax Harmonisation Law establishes uniform rules for the subject of tax liability, the object of the tax and the tax period, procedural law and the law relating to tax offences, but different tax brackets, rates and allowances remain. The most significant divergence arises through competing tax exemptions. Cantons, in consultation with the communes within their borders, have the discretion to grant tax exemptions or holidays, either partial or full, to newly-established businesses for up to ten years to further economic development objectives such as inward investment of capital and local employment targets. ${ }^{128}$ Given this discretion in tax reductions/exemptions, the tax bases of the Swiss cantons are not fully harmonised. However, in practice the tax bases are often very similar.

\subsubsection{Tax base consolidation}

The income of intercantonal business activities of a corporation is consolidated at the individual corporation level only. Thus, income of intercantonal activities through a branch is included, but income from business activities of subsidiary or other affiliated corporations is not. In the case of overall losses, the loss can be carried forward to offset future profits. Corporate group consolidated returns are not permitted in Switzerland, and transactions between subsidiaries and other affiliates must be conducted and reported according to the arm's length principle. The income of each entity is reported separately and not as a group, and only in cases where the entity is found to be established for tax avoidance purposes and where the parent retains control over the entity and beneficial ownership of the capital and profits of the entity will the letter box company be ignored and treated as part of the parent company. For Swiss PEs of foreign corporations, taxable income is determined through separate accounting.

\footnotetext{
127 A PE has been defined in Swiss Supreme Court case law as a lasting physical installation or facility in which a qualitative and quantitative material part of the commercial or technical activities of an enterprise is exercised. Intellectual property or accounts receivable by themselves cannot create a PE; physical presence is required. However, use of the assets, whether by agreement or otherwise, can be sufficient. Additionally, the installation, facility or other physical presence must belong to the business to which they are purported to be a part of. Finally, the qualitative and quantitative aspects are to be construed broadly as the aim is not to split the tax base among the cantons unnecessarily.

128 Tax holidays are granted to new business for up to 10 years. See Federal Tax Law Art.3 para. 23. The exemption benefits are also usually subject to recapture if the business leaves the jurisdiction within 10 years of the holiday. For example, in the Canton of Zurich a tax allowance may be granted as a percentage reduction on taxes on corporate profits and capital with a tax deduction for expenses incurred in the course of business. Companies are encouraged to consult with the Cantonal Tax Authority before assessment for a binding determination of tax classification, and taxation treatment. See Kanton Zurich Finanzdirektion Steueramt, Canton of Zurich as business location, available at <http://www.steueramt.zh.ch/internet/finanzdirektion/ksta/en/business_location.html>.
} 


\subsubsection{Tax base allocation and apportionment}

This consolidated income includes all income derived from the business, including investment property income from main and secondary tax domiciles as well as income of foreign PEs and properties, plus dividends or capital gains on foreign participations. Income which is separate from the business income of the enterprise, such as passive investments, is subject to allocation. This income is first allocated to special tax domiciles and the remainder is apportioned between the primary tax domicile and any secondary tax domiciles. Income from holdings in other companies is apportioned (with the exception of banks). For example, interest income is allocated to specific tax domiciles in proportion to the value of assets located there. Capital gains on the value of investment property located outside the main tax domicile are allocated to the canton in which the property is located. The exception to this rule is where capital gains reflect a recapture of depreciation allowances; in this case, they will be allocated to the primary tax domicile.

In Switzerland, there are three different methods of apportionment: direct, indirect and a hybrid of the two. Direct apportionment involves the initial calculation of income of separate PEs of a legal entity where net income is not consolidated until after individual profit and loss has been determined through separate accounting. After these determinations, the individual profits/losses are consolidated and apportioned to the relevant cantons. This method can only be used if the PEs are managed as separate enterprises with their own accounting books. Although this is the preferred method of the Federal Supreme Court, in practice the method is rare and only primarily used by banks. For example, in the canton of Bern, only 1 per cent of intercantonal allocations occur through the direct method.

Through indirect apportionment, the income and expenses of intercantonal business activities of all PEs of a corporation are consolidated and this tax base is apportioned to cantons according to the respective ratio of factors of production present within their borders. These factors include turnover or gross receipts, payroll and assets. In principle, application of the indirect method is only acceptable when the direct method is insufficient; however, in practice the predominant method of apportionment is indirect.

Mixed apportionment allows application of different apportionment formulae to divergent business lines. First, each corporate division determines overall profit/loss according to separate accounting rules, and then this profit/loss is apportioned among the respective cantons. (See Diagram 6.) 


\section{Diagram 6 Tax base definition, consolidation, allocation and indirect apportionment in Swiss cantons}

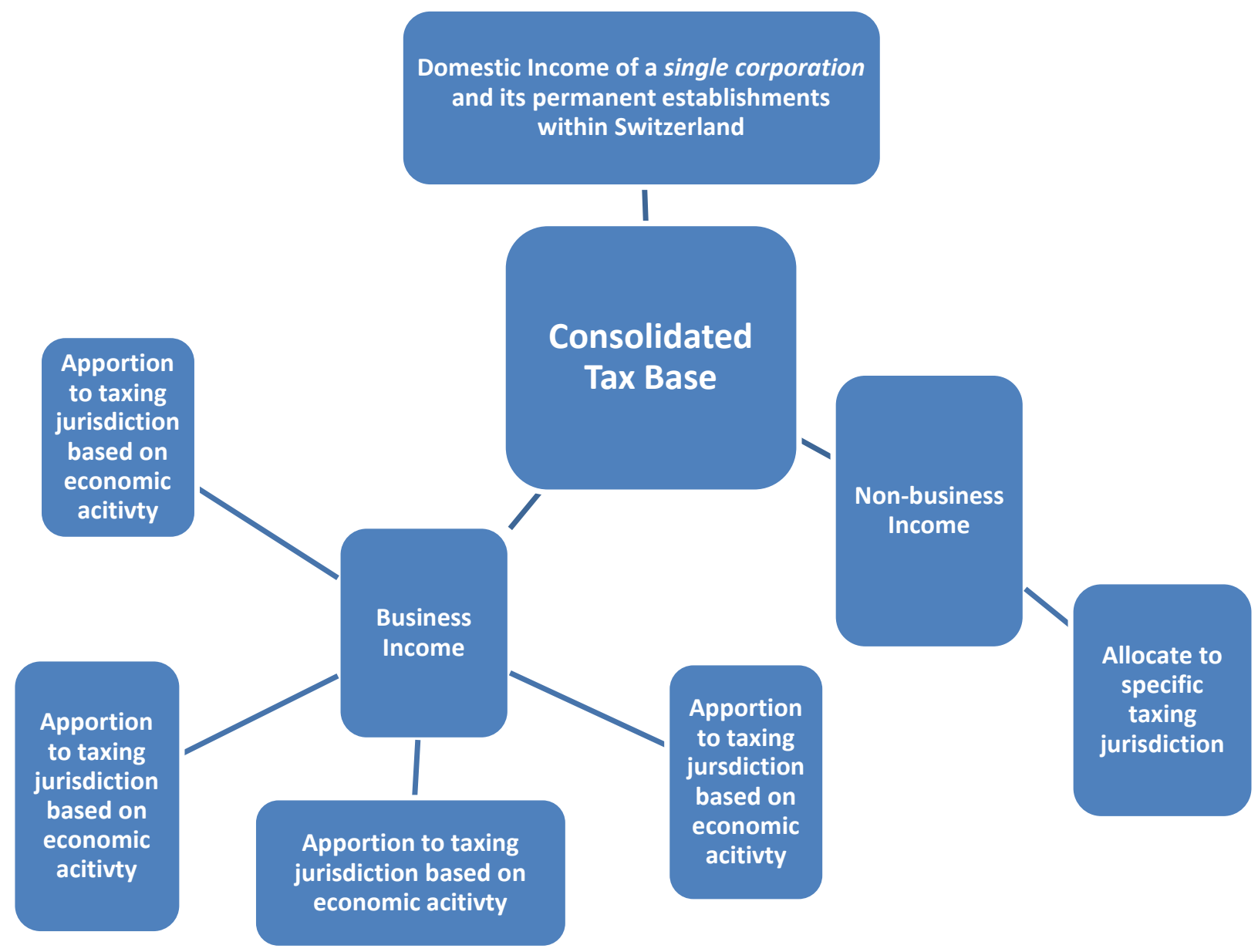

\section{Apportionment formulae}

No general standard formula of apportionment exists in Switzerland. Instead, different formulae have been developed over time through practice and confirmed on occasion by the Swiss Supreme Court for different industry sectors. These formulae are often negotiated by individual firms with the canton of primary tax domicile when the existing formula does not properly reflect the economic reality of the factors of production for the taxpayer. Each formula may also apply a corrective mechanism that attributes a certain percentage of the profits to the primary place of central management if it is perceived that too little profit is apportioned to the central management of the enterprise. This mechanism, called a Präzipuum, is applied on a case-by-case basis taking into account the structure and activities of the firm. General rules for industry sectors have been established through case law. For example, in the commercial, transportation and insurance sectors, a 20 per cent Präzipuum is usually allocated to the place of management; for professional services and manufacturing there is more flexibility. For the banking sector, even though it uses the direct method of separate accounting, a 10 per cent Präzipuum is allowed. ${ }^{129}$

Apart from the Präzipuum, for the retail commercial sector income is apportioned by a single factor - turnover or gross receipts - and is attributed to the PE regardless of the destination, 
reflecting a supply/source view of income. Additionally, if the goods sold vary substantially or are arranged in different product lines, profit margins may be taken into account to make corrections to apportionment factors.

The manufacturing sector includes traditional manufacturing along with construction businesses and electricity and water suppliers. Income is apportioned by capital and labour. The capital factor is comprised of the value of productive assets and rental and leasing fees and is capitalised at 6 per cent. Holdings in subsidiaries are included in the capital factor and generally attributable to the main tax domicile, while investment property and unproductive assets, which include intangibles, are excluded. For electricity companies and water suppliers, electrical lines, pipelines, transformers, substations and the like are assets which constitute a material part of the business and are included in the capital factor. The labour factor is comprised of annual wages and salaries, capitalised at 10 per cent. Wages paid to managers of investment property or unproductive assets are excluded. Income from the telecommunications sector is apportioned similarly to these other utilities, with participation income and gains allocated to the primary tax domicile but with no Präzipuum allowed. ${ }^{130}$

Income from intercantonal transportation industries is apportioned according to transportation activities, and tracks and stations count as PEs. Income from agricultural industries is apportioned by value of assets used in operations. Income from professional services, which include legal, medical and engineering services, are apportioned by fees. For large professional service companies, a payroll factor is also usually used.

Income from the insurance sector is generally apportioned by premium receipts. ${ }^{131}$ For post offices, only certain activities are taxable and taxable income is apportioned based on payroll. Income from intercantonal trusts are apportioned by fees but an apportionment formula may also take into account returns on assets managed and payroll. (See Table 4.)

\section{Table 4 Special apportionment formula rules in Swiss cantons}

\begin{tabular}{|l|l|}
\hline Special apportionment formula rules in Swiss cantons \\
\hline Industry & Special rule \\
\hline Retail commerce & Gross receipts (by source); profit margins taken into account \\
\hline $\begin{array}{l}\text { Manufacturing, construction, } \\
\text { electricity and water supply }\end{array}$ & $\begin{array}{l}\text { Capital (value of productive assets plus rental and leasing fees capitalised 6\%) } \\
\text { and labour (wages and salaries capitalised at 10\%) }\end{array}$ \\
\hline Transportation & By transportation activities; tracks and stations count as PEs \\
\hline Agricultural industries & Value of assets in operations \\
\hline Professional services & Fees; larger companies may include a payroll factor \\
\hline Insurance & Premium receipts \\
\hline Post offices & Payroll (only certain activities are taxable) \\
\hline Trusts & Fees; may also take into account returns on managed assets \\
\hline
\end{tabular}

\subsubsection{Administration, reporting and dispute resolution}

The canton which is the main tax domicile of the taxpayer conducts a review/audit of this assessment. Accounting methods are according to the Swiss Code of Obligations (civil law), and there are rarely any differences between tax and accounting reporting. There is flexibility in depreciation allowances as mentioned above, and the cantons have developed schedules of acceptable ranges. In any case, the reporting must be consistent between tax and accounting books. For taxpayers, there is an administrative appeal procedure, followed by

\footnotetext{
130 Apportionment of taxable income of the telecommunications sector is addressed in Swiss Federal Tax Administration, Circular 20 of 9 September 2009.

131 Swiss Federal Tax Administration, Circular 23 of 21 November 2006 contains special rules with respect to life insurance and non-life insurance companies, and provides that a general insurance agent is treated as a PE if there are more than three full-time employees.
} 
two levels of cantonal court review with the final authority given to the Swiss Supreme Court. Intercantonal disputes first involve bilateral negotiation (and conflicts are usually resolved this way) but may be brought before the Swiss Supreme Court.

\subsubsection{Conclusion}

In order for any unitary taxation approach to be successful, there must be a unifying principle as well as procedures in place that help the system run smoothly. ${ }^{132}$ For Switzerland, this principle can be found in the constitutional prohibition against double taxation. This requirement is interpreted very stringently by the Swiss Supreme Court - even prohibiting 'virtual' double taxation. Moreover, the Swiss culture of negotiation lends itself to conflict resolution before escalation, and is even encouraged as a preventative measure. New businesses are encouraged to consult the cantonal tax authority before assessment in order to gain approval on desired (and, of course, reasonable) tax treatment. On an intercantonal level, the Swiss Tax Conference includes members of cantonal and federal tax administrations, and builds cooperation in the administration of legislation, circulars, and bior multilateral agreements. Cantonal tax authorities also express confidence that other cantons are following the same rules.

Procedurally, although the tax bases of the cantons are not completely harmonised, there is a uniform tax accounting period, with the same taxable subject and objects, filing requirements (including standard tax forms), and uniform enforcement and appeal procedures. Furthermore, and importantly, there is a close proximity of accounting records to taxable income: taxable income is determined from the corporate profit and loss statements as determined by the Swiss Code of Obligations. Also, because each canton requires a reporting of worldwide income and capital, the information for accurate assessment is available to tax authorities. Within the context of a constitutional prohibition against double taxation, a culture of negotiation, the allowance of a certain degree of freedom to set tax rates, and flexibility in the apportionment factors for industry sectors, this unitary taxation approach works for the cantons of the Swiss Confederation.

\subsection{Corporate income apportionment in the United States}

\subsubsection{Political overview}

The United States (US) is a federal republic comprised of executive, legislative and judicial branches of government. There are fifty states and the federal District of Columbia (DC), with a total population of 315 million people. The US Constitution governs all federal and state laws. The federal and state governments share taxation powers, with the exception of import duties and duties of tonnage which are assessed exclusively at the federal level. ${ }^{133}$ Within these bounds, the states levy both direct and indirect taxes according to their constitutions, laws and regulations. There is no comprehensive federal harmonisation law for state taxation. Thus, among the fifty states and federal district, ${ }^{134}$ six states have no CIT, three of

\footnotetext{
132 Interviews with practitioners from both the public and private sectors indicated that it generally works well. Many thanks to Stephan Stauber, Director, Cantonal Tax Authority of Basel-Stadt and Regine Loepfe, Legal Division - Swiss Federal Tax Administration, Federal Department of Finance, for interviews on 1 July 2013.

133 Congress was not given exclusive power of taxation nor was state regulation or taxation of commerce proscribed except for duties on imports and exports (there was an exception for inspection expenses) and duties of tonnage. See US Const. Art. 1, § 10, cl. 2, cl. 3. See also Abel (1941) (arguing that most delegates involved in the constitutional debates thought congressional power over the regulation of interstate commerce should be exclusive but that the delegates also had a narrow understanding of what encompassed the regulation of interstate commerce). Additionally, the US Constitution prohibits taxation of exports at the federal level. US Const. Art. 1, § 10, cl. 5. Hereinafter, DC will be included with states.
} 
those six levy gross receipts tax on business activity, ${ }^{135}$ and each of the forty-six states with a CIT has its own enacting legislation and regulation. ${ }^{136}$

The US Constitution, as interpreted by the federal Supreme Court, establishes the legal framework for the American common market. ${ }^{137}$ The Commerce Clause figures prominently in multistate taxation jurisprudence. ${ }^{138}$ The Commerce Clause does not explicitly forbid state regulation of interstate commerce; however, the doctrine of the dormant or negative Commerce Clause - the power over interstate commerce that may not be exercised by the states - emerged in the beginning of the Supreme Court's jurisprudence on the Commerce Clause in the landmark ruling of Gibbons v. Ogden in $1824 .{ }^{139}$ At the same time, as early as the late 1800 s, there was a growing consensus on the ability of states to rightfully tax the fruits of commerce, whether engaged in intra- or inter-state business, and whether from the property, capital stock, or income of its citizens or private corporations operating within its borders. ${ }^{140}$ In an open federal market, commerce increasingly took on an interstate character: express courier, railroads, and telegraph companies flourished by the mid-1800s and quickly became subjects of state taxation.

In this context, the 'unit rule' became the judicially accepted mode of tax assessment on property and company gross receipts. ${ }^{141}$ The unit rule provides that in the determination of the tax base, the property or gross receipts of a taxpayer is first valued as a whole and then apportioned among tax jurisdictions according to some constant value, such as track or telegraph miles (Isaacs 1926: 838). Later, when Congress enacted a CIT in 1913 and many of the states followed, the unit rule was applied to the net income from multistate business activities. Thus, this early concept, which came to be known as the unitary business principle constitutes the American approach to unitary taxation.

135 Ohio, Texas and Washington. See Tax Foundation, State Corporate Income Tax Rates, 2000-2013, available at $<$ http://taxfoundation.org/article/state-corporate-income-tax-rates-2000-2013>.

136 Under the authority of the US Constitution, each state's constitution grants powers to legislate on taxes and where applicable each state has its own laws and regulations on corporate income taxation. For example, the Florida Constitution provides that CIT is not to exceed $5 \%$. The laws of Florida provide that the CIT rate is $5.5 \%$ (proportional) and the administrative code of Florida provides supporting regulations. Fla. Const. Art VII, §5(b); Fla. Stat. 220.11(2); Fla. Admin. Code 12C-1.011. Some states have graduated rates for increasing income brackets, while others have a single proportional rate. Proportional rates range from $4.63 \%-9.99 \%$ while graduated rates of the top income bracket range from $6 \%-12 \%$. Total revenue from state CITs in 2010 was US $\$ 38.2$ billion. In comparison, revenue from federal CIT from the same year was US $\$ 242$ billion with graduated rates ranging from $15 \%$ for incomes up to US $\$ 50,000$ to $35 \%$ for income levels over US $\$ 10$ million. However, the average effective tax rate for profitable corporations is estimated at only 17\%. See Tax Foundation, State Corporate Income Tax Rates, 2000-2013; US Department of Commerce, Bureau of Economic Analysis, Table 3.20, column 2010, State Government Current Receipts and Expenditures; US Government Accountability Office (2013). This Effective Tax Rate includes state and local taxes paid. The study also found that 'profitable US corporations that filed a Schedule M-3 paid US federal income taxes amounting to about 13 per cent of the pretax worldwide income that they reported in their financial statements (for those entities included in their tax returns)'.

137 Since the early 1800 s, through the major phases of economic expansion - from the development of steam-powered engines, the telegraph and railroads to the automobile, electricity, indoor plumbing and most recently, computers and the Internet - several constitutional provisions have set the parameters for federal regulation of interstate commerce visà-vis the taxing jurisdiction of the states: the Commerce Clause (US Const. Art. 1, § 8, cl. 3); the Equal Protection Clause (amend. XIV § 1, cl. 3); Due Process Clause (amend. V, XIV § 1. cl. 2); Privileges and Immunities Clause (US Const. Art. 4, § 2, cl. 1, amend. XIV § 1. cl. 1); Import-Export Clause (US Const. Art. 1, § 10, cl. 2); and Duty of Tonnage Clause (US Const. Art. 1, § 10, cl. 3). Additionally, Congress has the 'Power To lay and collect Taxes, Duties, Imposts and Excises, to pay the Debts and provide for the common Defence and general Welfare of the United States' (US Const. Art. $1, \S 8, \mathrm{cl} .1$ ), while States are not allowed to lay any duties on imports or exports or any duties of tonnage without the consent of Congress (US Const. Art. 1, § 10, cl.2, 3).

The Commerce Clause grants Congress the authority to regulate commerce 'with foreign Nations, and among the several States, and with the Indian Tribes'. US Const. Art. 1, § 8, cl. 3.

139 Gibbons v. Ogden, 22 US 1, 189 (1824).

140 See, e.g., Society for Savings v. Coite, 73 US 594, 607 (1867); The Delaware Railroad Tax, 85 US 206, 232 (1873); Pullman's Palace Car Co. v. Pennsylvania, 141 US 18, 23 (1891) ('It is equally well settled that there is nothing in the Constitution or laws of the United States which prevents a state from taxing personal property employed in interstate or foreign commerce like other personal property within its jurisdiction.')

141 See State Railroad Tax Cases, 92 US 575 (1875) where tax assessed on the total value of the company property, apportioned according to track mileage located within the state, was upheld by the US Supreme Court. 
In 1957, the Uniform Law Commission developed the Uniform Division of Income for Tax Purposes Act (UDITPA) to provide uniformity in state apportionment of the tax base, but by 1964, when only three states had adopted UDITPA, Congress commissioned the Willis Committee, which recommended federal harmonisation and consolidation of the income tax base for multistate businesses (Huddleston and Sicilian 2009). In reaction, states joined together to develop the Multistate Tax Compact (MTC), which provided model legislation for dividing the CIT base (but not how to determine the tax base). By 1967, the MTC, which incorporated UDITPA into Article IV, came into force. ${ }^{142}$ The MTC also created the Multistate Tax Commission, an agency to assist state tax authorities in administering tax laws in regard to multistate and multinational corporate taxpayers. ${ }^{143}$ All US states with a CIT aggregate and apportion the income tax base for corporations with multistate business activities and roughly use a similar framework as provided in the MTC; however, the variations within this framework are myriad. ${ }^{144}$

Through over a century of Supreme Court Commerce Clause jurisprudence on multistate taxation several guiding themes have emerged, but only three have risen to prominence in contemporary constitutional parlance: economic connection or nexus to establish taxing jurisdiction; non-discrimination of interstate commerce; and fair apportionment of the tax base among taxing jurisdictions.

Taxing jurisdiction, also known as economic nexus, may be challenged under either the Commerce Clause or the Due Process Clause. Under the Due Process Clause, the economic nexus must be 'some definite link, some minimum connection, between a state and the person, property or transaction it seeks to tax', ${ }^{145}$ while under the Commerce Clause, the economic nexus must be a 'substantial nexus'. ${ }^{146}$ The MTC established the model statute, 'Factor Presence Standard for Business Activity Taxes', in 2002 to provide a threshold for economic nexus based on the presence of minimum amounts of property (US $\$ 50,000)$, payroll (US\$50,000) or sales (US\$500,000); or 25 per cent of total property, payroll or sales. However, only a few states have adopted nexus thresholds based on the MTC model statute. California and Colorado impose an income tax on corporations doing business in the state, and defines doing business according to the MTC standards. ${ }^{147}$ Michigan, however, levies an income tax on taxpayers with business activity within the state, and defines substantial nexus with the state as physical presence for more than one day, active solicitation of sales plus US $\$ 350,000$ gross receipts sourced in Michigan, or ownership interest in a flow-through entity with substantial nexus to the state. ${ }^{148}$ Connecticut regulations list a number of nexus-creating activities, such as owning or leasing real property, performing or soliciting orders for services, or selling or soliciting orders for real property. ${ }^{149}$ New York has also recently enacted an economic nexus rule under its Corporate Franchise (income)

142 Currently, the MTC has proposed a revision to UDITPA which includes: 1) defining business income as all income apportionable under the US Constitution; 2) replacing cost-of-performance sourcing of intangibles and services to market-based sourcing; 3) excluding hedging transactions and treasury receipts from the sales factor; 4) recommending a double-weighted sales, property and payroll apportionment formula while allowing states to choose any apportionment formula; 5) allowing states to choose any alternative relief formula for particular industries under the equitable apportionment article. The revisions are now under consideration by the MTC executive committee. See Richard Pomp, Multistate Tax Commission, Report of the Hearing Officer, Multistate Tax Compact Article IV [UDITPA] Proposed Amendments (25 October 2013).

143 Currently, 48 states are members of the Multistate Tax Commission; 17 have adopted the MTC and the remainder are sovereignty or project members. Multistate Tax Commission, accessible at <http://www.mtc.gov>.

144 All but 12 states have either adopted UDITPA or have similar provisions. Colorado, Connecticut, Maryland, Massachusetts, Michigan, Minnesota, New Jersey, New York, South Carolina, Texas, Virginia and West Virginia have markedly diverse approaches. See CCH Multistate Quick Answer Charts, UDITPA Uniformity. Quill Corp. v. North Dakota, 504 US 298 (1992). 
Tax that establishes tax jurisdiction over corporations deriving at least US\$1 million in receipts from the state. ${ }^{150}$

In 1959, Congress adopted a limitation on nexus through federal legislation. Public Law 86272 prohibits taxation of corporations which only solicit orders for tangible goods in a state if they are approved and shipped from outside the state. ${ }^{151}$ However, the impact of this law can be largely eviscerated through state-legislated throwback rules in the apportionment formulae, which assign sales that take place in a non-taxable state back to the state of shipment. ${ }^{152}$ Additionally, Public Law 86-272 does not apply to income generated from the sale of intangible goods, such as services. In these cases, some state courts have extended the nexus requirement beyond physical presence to significant economic presence, which involves examination of the quality and quantity of economic contacts as well as the frequency, quantity and systematic nature of a taxpayer's economic contacts with a state. For example, in MBNA America Bank, the taxpayer had no physical presence in the state of West Virginia, but because MBNA 'systematically and continuously engaged in direct mail and telephone and solicitation and promotion in the state' and had 'significant gross receipts attributable to customers in the state' (from financial services) the state court found a significant economic presence under both the Due Process and Commerce Clauses. The federal Supreme Court has denied further appeals to review these nexus-extending state court rulings. ${ }^{153}$

Under the constitutional principle of non-discrimination, a state may not levy a tax which discriminates against interstate commerce 'either by providing a direct commercial advantage to local business, or subjecting interstate commerce to the burden of multiple taxation'. ${ }^{154}$ However, even purely interstate activities may be taxed if the tax base is fairly apportioned among the states.

Under the constitutional requirement of fair apportionment, the unitary business principle governs the consolidation of income from multistate business activities for CIT purposes. While the federal Supreme Court has not explicitly defined the term 'unitary business', it has indicated certain characteristics of a unitary business, including 'functional integration, centralisation of management, and economies of scale'. ${ }^{155}$ The federal Supreme Court has stated that "unitary taxation "rejects geographical or transactional accounting", which is "subject to manipulation" and does not fully capture "the many subtle and largely unquantifiable transfers of value that take place among the components of a single enterprise"'. ${ }^{156}$ Fair apportionment of income also requires a 'rational relationship' between

150 NY Tax Code Sec. 209; see also NY Budget Bill S6395D-2013 (effective 1 January 2015).

15115 USC. 381-384

152 See footnotes $182-186$ for discussion of throwback rules as a response to P.L. 86-272. See also Pomp (2009) at 10-24$25,11-12-23$ for further analysis.

153 See, e.g., Tax Comm'r of the State of West Virginia v. MBNA America Bank, 650 SE 2d 226(2006), cert denied sub nom, FIA Card Services N.A. v. Tax Comm'r of West Virginia, 551 US 1141 (2007) (limiting Quill Corp. v. North Dakota 504 US 298 (1992) physical presence requirement to sales and use taxes); Geoffrey, Inc. v. South Carolina Tax Comm'n, 437 SE 2d 13 (1993), cert denied 114 S. Ct. 550 (1993) (same). West Virginia's provision regarding tax jurisdiction is identical to the UDITPA provision as stated above. See W.V. Code Sec. 11-24-7.

$154 \quad$ Northwestern States Portland Cement Co. v. Minnesota, 358 US 450 (1959) (upholding an income tax levied directly on the profits of a corporation conducting an exclusively interstate business).

155 See, e.g., Mobil Oil Corp. v. Comm'r of Taxes State of Vermont, 445 US 425. 438 (1980) (citing Butler Bros. v. McColgan, 315 US 501 at 508-09 (1942)). Moreover, regarding manufacturing processes, the Court has held that 'the enterprise of a corporation which manufactures and sells its manufactured product is ordinarily a unitary business, and all the factors in that enterprise are essential to the realization of profits'. Hans Rees' Sons Inc. v. North Carolina, 283 US 123, 133 (1931).

156 Barclays Bank v. Franchise Tax Board of California, 512 US 298, 303 (1994) (citing Container Corp. v. Franchise Tax Board of California, 463 US 159 (1983)). Moreover, when 'factors of profitability arise from the operation of the business as a whole, it becomes misleading to characterize the income of the business as having a single identifiable "source". Although separate geographical accounting may be useful for internal auditing, for purposes of state taxation, it is not constitutionally required. . . the linchpin of apportionability in the field of state income taxation is the unitary business principle'. Mobil Oil Corp. v. Comm'r of Taxes State of Vermont, 445 US 425 at 438-39 (1980). 
the income attributed to the state and the intrastate 'values of the enterprise'. ${ }^{157}$ The Court has stated that fair apportionment does not require uniform apportionment formulae throughout the fifty states, but it must be internally and externally consistent. ${ }^{158}$

\subsubsection{Tax base harmonisation}

Although states are not obligated to abide by a uniformly-derived taxable income base, in practice all states with a CIT take federal taxable income as a starting point (Duncan 2005). Given this general uniformity, the tax base is comprised of gross income ${ }^{159}$ less allowable deductions. ${ }^{160}$ Tax incentives offered by states for economic development or social purposes create the greatest source of divergence of tax base definitions among the states. ${ }^{161}$ Additionally, schedules for depreciation of capital assets may also differ from federal allowances. Prior to the enactment in 2002 of bonus depreciation all but two states conformed to federal depreciation allowances; ${ }^{162}$ now less than two-thirds of states conform to federal rules. ${ }^{163}$

\subsubsection{Tax base consolidation}

The tax base for a multinational corporation may be consolidated only in terms of its domestic business activities under a water's edge approach. Under this approach, only domestic income (and losses) are pooled together for apportionment among the subnational taxing jurisdictions which have some economic connection to the income. However, if the tax base for a multinational is consolidated through a worldwide approach (often referred to as worldwide combined reporting (WWCR)) all its income (and losses), both domestic and foreign-sourced, are pooled together for apportionment among the worldwide taxing jurisdictions which have some economic connection to the income. It is important to note that under the worldwide approach, the inclusion of worldwide income requires inclusion of foreign losses and foreign factors of production in the apportionment formula. This broader consolidation affects the total income to be apportioned as well as the percentage of apportionment of that total income and may not necessarily result in double taxation. ${ }^{164}$

157 See, e.g., Moorman Manufacturing Co. v. Bair, Director Revenue of lowa, 437 US 267 (1978) (upholding lowa's single sales formulae despite a prevalence of three-factor formulae in the states).

Internal consistency requires that the formula - if applied by every jurisdiction - taxes no more than $100 \%$ of income from the unitary business. External consistency requires that the factors represent a reasonable sense of how the income is generated. Moorman Manufacturing Co. v. Bair, Director Revenue of lowa, 437 US 267 (1978). The Moorman Court noted in dicta that 'It is clear that the legislative power granted to the Congress by the Commerce Clause of the Constitution would amply justify the enactment of legislation requiring all States to adhere to uniform rules for the division of income'. See also Container Corp. of America v. Franchise Tax Board, 463 US 159 (1983).

Gross income means income derived from any source, including gross profit from the sale of goods and services to customers, rents, royalties, interest (other than tax-exempt interest from state and local bonds), dividends, gains from the sale of business property, alimony, income from discharge of debt, annuities, pensions and other sources. 26 USC. $\S 61$.

160 Allowable deductions include ordinary and necessary business expenditure, such as salaries, wages, contributions to profit-sharing and pension plans and other employee benefit programmes, repairs, bad debts, contributions to charitable organisations (subject to an income limitation), advertising, interest expense, certain losses, selling expenses, and other expenses. 26 USC $\S 161$ et. seq. Net operating losses may be carried back 2 years and carried forward 20 years. 26 USC \$ 172. There is a dividends received deduction for related corporations along with other deductions and credits for encouraged economic activities. For example, the Alternative Motor Vehicle Credit, Manufacturer's Energy Efficient Appliance Credit, Plug-In Electric Drive Vehicle Credit, Research Credit, etc. 26 USC § 243.

161 For example, every state has an extensive tax incentive scheme (layered over a federal incentive scheme) to encourage development of renewable and energy-efficient technologies; 45 states offer various incentives for film production; 16 states offer tax incentives for land conservation; and many states offer incentives for job creation, training, and low-income housing development. It has been estimated that over US $\$ 64$ billion in the last 35 years has been awarded in such incentives by state and local governments. See Mattera and Tarczynska (2013); see also Good Jobs First, Subsidy Tracker Database with a comprehensive list of all state and local subsidies, available at <http://www.goodjobsfirst.org/subsidy-tracker> accessed 30 July 2013. P.L. 107-147 and P.L. 108-27.

See Duncan (2005).

McIntyre and Pomp (1995) (arguing that WWCR does not systematically result in double taxation because it incorporates worldwide losses and also decreases the percentage of apportionment due to the inclusion of worldwide factors of production). 
Until the mid-1990s, several states, including California, used the worldwide approach for consolidating the tax base of multinationals. In 1983, in Container Corp. of America v. Franchise Tax Board, ${ }^{165}$ the federal Supreme Court upheld the California law as applied to a domestic-based multinational; later, in 1994, the Court upheld the law as applied to a foreign multinational in Barclays Bank PLC v. Franchise Tax Board. ${ }^{166}$ Domestic and foreign reaction to these rulings was swift, forcing states with WWCR to amend their laws to provide for water's edge reporting or a water's edge election with special conditions. ${ }^{167}$

Today, there are fifteen states where WWCR is permitted or required in certain circumstances: Alaska, California, Colorado, District of Columbia, Idaho, Illinois, Massachusetts, Montana, Nebraska, New Hampshire, North Dakota, Utah, Vermont, West Virginia and Wisconsin. ${ }^{168}$ In total, there are twenty-eight states that provide for at least water's edge combined reporting either on an elective or mandatory basis, while seventeen states do not allow combined reporting and require separate reporting. ${ }^{169}$ Of the fifteen states which allow or require WWCR in certain circumstances, California, Idaho, Montana, and North Dakota provide for a water's edge election. This election generally requires that corporations with more than 50 per cent of their stock owned or controlled by the same interests (directly or indirectly) are in the water's edge group, along with domestic international sales corporations, foreign sales corporations, export trade corporations, foreign corporations deriving gain or loss from disposition of a United States real property interest, and any foreign corporation where more than 20 per cent of the average of its property, payroll and sales factors is located in the US. ${ }^{170}$ Alaska, Montana, Oregon and West Virginia also include income from certain foreign corporations located in low- or no-tax jurisdictions. The other states with WWCR generally allow the exclusion of foreign income if at least 80 per cent of the payroll and property of the foreign affiliate is located outside the US. ${ }^{171}$

As discussed above, the unitary business principle acts as a constitutional restraint on a state's consolidation of the tax base. Driven by a facts and circumstances analysis, this principle often involves a consideration by tax authorities of the economic reality of each business. The MTC provides a lengthy analysis of principles in determining the existence of a unitary business in Regulation IV.1(b) (and many states have adopted similar definitions), which provides in part:

165463 US 159 (1983).

166114 S. Ct. 2268 (1994) (noting that the law did not create an undue risk of multiple taxation or impair the federal government's ability to 'speak with one voice when regulating commercial relations with foreign governments' as was the case in Japan Line, Ltd. v. County of Los Angeles, 441 US 434, 449 (1979)).

167 After the Container ruling, a working group, commissioned by President Ronald Reagan, recommended water's edge unitary combination for both US and foreign-based companies, and federal legislation if states failed to make progress (Department of the Treasury, The Chairman's Report on the Worldwide Unitary Taxation Working Group, iii, 9 (July 1984)). After 10 years had passed with no change, the Barclays case sparked charges by the European Commission of tax treaty violations along with more intense pressure from the business lobby. The Report states: 'Some US states ... assess state CIT for foreign-owned companies operating within their state borders on the basis of an arbitrarily calculated proportion of the total world-wide profits of the company. This proportion of total world-wide earnings is assessed in such a way that a company may have to pay tax on income arising outside the state, which may give rise to double taxation ... EU companies consider their planning to be adversely affected under these circumstances. The EU and its Member States will continue to closely monitor any development. Discussions continue within the OECD Committee on Fiscal Affairs' (European Commission 1994: 49-50); see also Mclntyre and Pomp (1995) (commenting on the Report of the EC); Pomp (2009).

See CCH Multistate Quick Answer Charts, Combined Reporting. 'Certain conditions' refers to the exclusion of foreign affiliate income only if $80 \%$ or more of affiliate's average property and payroll factors are assigned to locations outside the US.

169 See CCH Multistate Quick Answer Charts, Combined Reporting.

170 See, e.g., Montana Code, Title XV, Ch. 31, Part. 3. A water's edge election is a 'three-year election effective only if every affiliated corporation subject to the taxes imposed under this chapter consents to the election. Consent by the common parent of an affiliated group constitutes consent of all members of the group ... The election must disclose the identity of the taxpayer and the identity of any affiliated corporation, including an affiliated corporation incorporated in a tax haven. Dividend from a corporation required to be combined in the water's-edge combined group must be eliminated from the calculation of apportionable income' (CCH Multistate Quick Answer Charts, Combined Reporting). 
A unitary business is a single economic enterprise that is made up either of separate parts of a single business entity or of a commonly controlled group of business entities that are sufficiently interdependent, integrated and interrelated through their activities so as to provide a synergy and mutual benefit that produces a sharing or exchange of value among them and a significant flow of value to the separate parts.

(MTC Regulation IV.1(b))

Along with a definition and indicators of a unitary business, the MTC regulation also provides a control analysis for determining the existence of a unitary business, which provides that 'separate corporations can be part of a unitary business only if they are members of a commonly controlled group'. ${ }^{172}$ While some states have applied the two-step test of control and relationship in consolidating income based on the MTC regulation, most have adopted the two-step test with the federal 'affiliated group' definition to determine control. ${ }^{173}$

\subsubsection{Tax base allocation and apportionment}

Under the US approach to unitary taxation, there is a distinction between types of income: business and non-business. Non-business income is allocated to a specific jurisdiction, while business income is apportioned among taxing jurisdictions. The MTC model statute ${ }^{174}$ provides that business income includes income arising from transactions and activity in the regular course of the taxpayer's trade or business, and includes income from tangible and intangible property if the acquisition, management and disposition of the property constitute integral parts of the taxpayer's regular trade or business operations. Non-business income means all income other than business income. ${ }^{175}$ Most states follow this approach to dividing the tax base between business and non-business income, but some states do not or provide alternate methods to allocating income. For example, Connecticut, Maine, Michigan, Nebraska, New Hampshire, North Carolina and Rhode Island apportion all net income of the taxpayer, while Colorado provides an option for non-business income to be either directly allocated according to MTC rules or apportioned by a single sales factor formula. ${ }^{176}$

In sum, after the tax base has been (1) aggregated either on a water's edge or worldwide basis, through either the two-step relationship test of the unitary business principle and the control/ownership test, or by control alone, or only at the entity level, according to state consolidation laws; the tax base is then (2) split between business and non-business income,

172 A commonly-controlled group is defined under the following conditions: (1) there is a parent corporation and any one or more corporations or chains of corporations, connected through stock ownership (or constructive ownership) where the parent owns stock possessing more than 50 per cent of the voting power of at least one corporation; or (2) there are any two or more corporations, if stock possessing more than 50 per cent of the voting power of the corporations is owned, or constructively owned, by the same person or by members of the same family; or (3) there are two are more corporations which constitute 'stapled entities' (more than 50 per cent of the ownership of voting stock consists of interests with restrictions on transfer or other restrictions connected with the form of ownership).

173 The federal definition defines members of an affiliated group as includible corporations connected through stock ownership with a common parent, where (1) the common parent owns at least 80 per cent of the total voting power and has a value equal to at least 80 per cent of the total value, and (2) the includible corporation is owned directly by 1 or more of the other includible corporations. 26 USC $\S 1504$.

174 See also MTC Reg. IV.1(a) which provides a transactional and functional test to determine whether an item of income may be attributed to business or non-business income.

175 To the extent that they constitute non-business income, net rents and royalties and capital gains and losses from sales of real estate located in the state are allocable to the state. Capital gains and losses from sales of intangible personal property and interest and dividends are allocable to the state if the taxpayer's commercial domicile is in the state. Capital gains and losses from sales of tangible personal property are allocable to a state if the property had a situs in that state at the time of the sale, or the taxpayer's commercial domicile is in the state and the taxpayer is not taxable in the state in which the property had a situs. Net rents and royalties from tangible personal property and patent and copyright royalties are allocable to a state: if and to the extent that the property is utilised in the state, or in their entirety if the taxpayer's commercial domicile is in the state and the taxpayer is not organised under the laws of or taxable in the state in which the property is utilised.

176 See CCH Multistate Quick Answer Charts, Business or Non-business Income Classification. 
or not split at all, according to state division of income laws; and then is (3) allocated if appropriate; and/or (4) apportioned among taxing jurisdictions through a formula, with factors representing economic factors of production (see Diagram 7).

\section{Diagram 7 Tax base definition, consolidation, allocation and apportionment in US states}

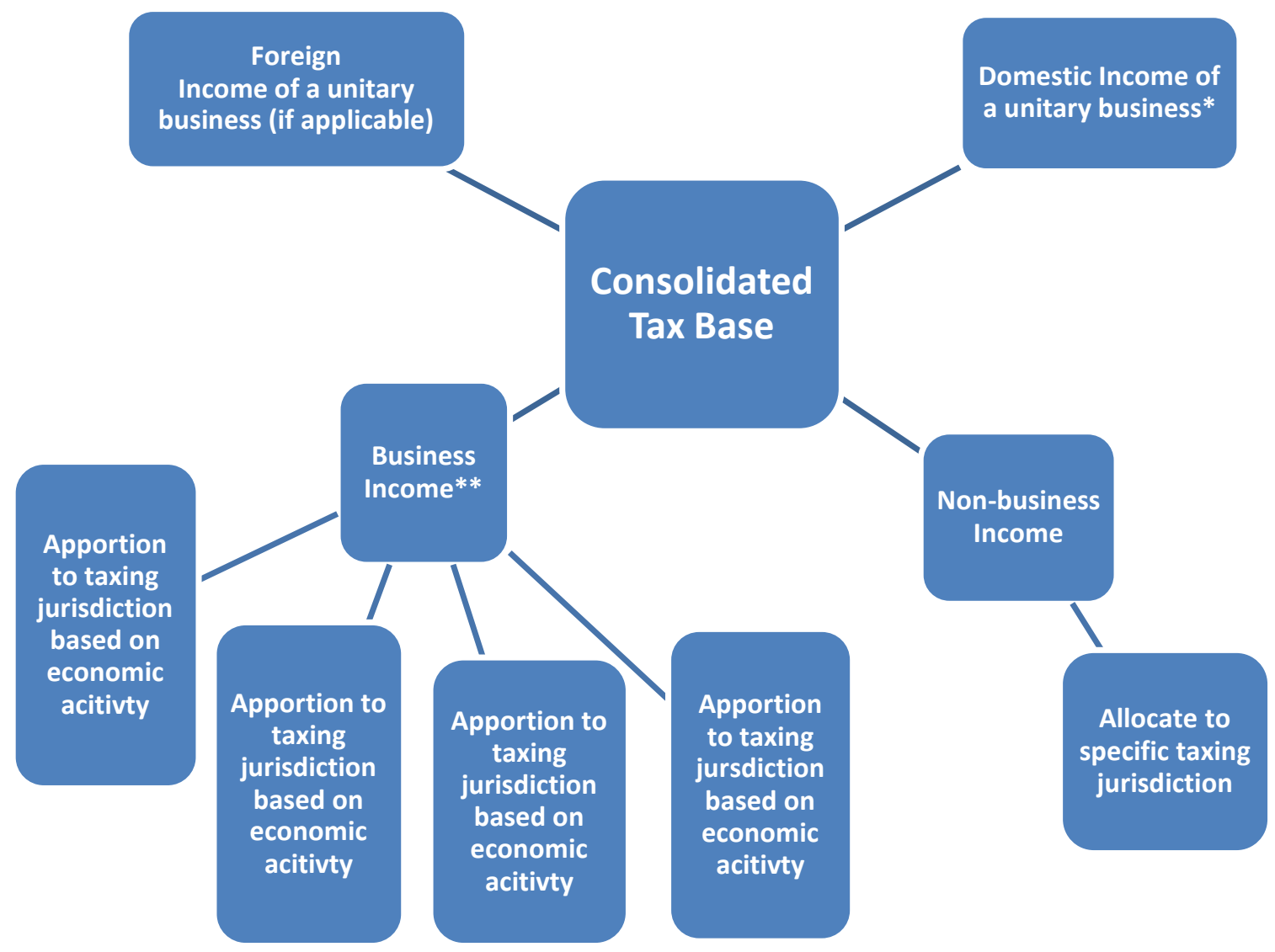

\footnotetext{
* Most states only consolidate domestic income; however, several consolidate on a worldwide basis.

${ }^{* *}$ A few states do not split the tax base between business and non-business income and consider all income as business income.
}

Various apportionment formulae are currently used by different states, including a threefactor formula with equally-weighted sales, payroll and property; the same formula with double-weighted sales; a single sales formula; or more creative formulae reflecting a transition to single sales, such as 80 per cent sales, 10 per cent payroll, 10 per cent property; ${ }^{177} 96$ per cent sales, 2 per cent payroll, 2 per cent property; ${ }^{178}$ or 90 per cent sales, 5 per cent payroll, 5 per cent property; ${ }^{179}$ with the majority of states either legislating a single sales factor (sixteen) or a double-weighted sales factor (seventeen). Currently, only twelve states have adopted an equally-weighted three-factor formula, which is provided by the MTC rule. Historically, the three-factor 'Massachusetts formula' was the dominant formula by the 1950 s - though not the only one. In 1920, the US Supreme Court upheld an apportionment

\footnotetext{
177 Arizona. From 2017, there will be a single sales factor. See CCH Multistate Quick Answer Charts, Apportionment Formulas.

178 Minnesota. From 2014, there will be a single sales factor. See CCH Multistate Quick Answer Charts, Apportionment Formulas.

179 New Jersey. From 2013, the formula will be single sales. See CCH Multistate Quick Answer Charts, Apportionment Formulas.
} 
formula based on a single asset factor used by the state of Connecticut. ${ }^{180}$ lowa used a single sales factor as early as 1934, and in 1978 this formula was upheld by the US Supreme Court in Moorman. ${ }^{181}$ In the 1990s, adoption of the single sales formula increased as states sought to attract economic investment (see Chart 1 below). However, from data covering the period 1986-2012, Clausing (2014) demonstrates that increased adoption of the single sales factor has not resulted in increased economic activity, but instead has only resulted in decreased corporate tax revenue.

\section{Chart 1 Evolution of US state apportionment formulae}

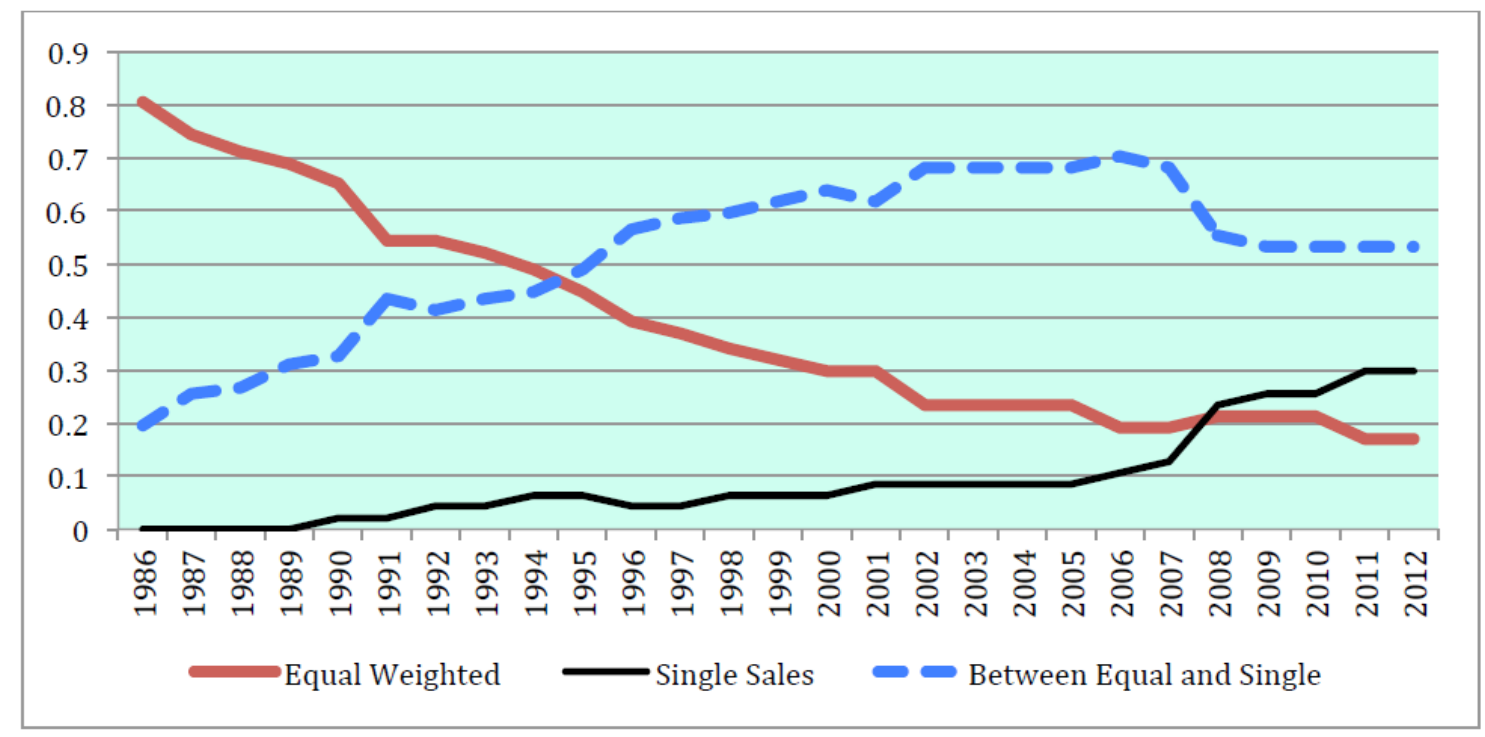

Source: Clausing (2014)

According to the MTC, the sales factor numerator includes the total sales of the taxpayer in the state, and the denominator includes the total sales of the taxpayer everywhere (either worldwide or water's edge depending on the laws of the state). Sales of tangible personal property are destination-based with a throwback rule where the property is shipped from an office, store, warehouse, factory, or other place of storage in the state and the purchaser is the government or non-taxable in the state of the purchaser. ${ }^{182}$ All states have destinationbased sales rules, and all but seventeen states have throwback or throw-out rules. ${ }^{183}$ Throwback rules have emerged in response to physical presence requirements in establishing nexus for taxing jurisdiction, and also to Public Law 86-272, which prohibits taxation of corporations which only solicit orders for tangible goods in a state. ${ }^{184}$ However, of the sixteen states that have a single sales formula, only half of those have throwback or

\footnotetext{
180 See Underwood Typewriter Co. v. Chamberlain, Treasurer of the State of Connecticut, 254 US 113 (1920). Four years later, the Court upheld a similar factor used by New York. See Bass, Ratcliff \& Gretton, Ltd.v. State Tax Comm'n, 266 US 271 (1924). The tax under review was a corporate franchise tax of $3 \%$ based on the net income of the corporation. The taxpayer was a British corporation, which imported and sold beer in the US through its branch offices in New York and Chicago.

181 See Moorman Mfg. Co. v. Bair, 437 US 267 (1978).

182 The throwback rule applies when a corporation has sales in a state but insufficient nexus to be subject to $\mathrm{CIT}$ in that state under P.L. 86-272.

183 Throw-out rules eliminate sales receipts from the factor completely. Maine and West Virginia have throw-out rules currently in force. See CCH Multistate Quick Answer Charts, Sales factors. See footnote 151 .
} 
throw-out rules. ${ }^{185}$ Combined with a destination-based single sales apportionment formula, this results in a significant loss of tax revenue. ${ }^{186}$

For sales of services and other intangibles, the sales are sourced where the incomeproducing activity is performed; or if the income-producing activity is performed in more than one state, it is sourced in the state in which a greater proportion of the activity is performed, based on costs of performance. ${ }^{187}$ All but seventeen states have adopted these sourcing rules for intangibles. ${ }^{188}$

The payroll factor numerator includes total amounts paid in the state for employee compensation, and the denominator includes total compensation paid everywhere. Compensation to employees does not include such payments made to independent contractors. ${ }^{189}$ From the states which have a payroll factor, several exclude income paid to executive officers, including: Delaware, New York, North Carolina, Oklahoma and South Carolina. ${ }^{190}$ The property factor numerator includes the average value of the taxpayer's real and tangible personal property owned or rented (in the legal sense) and used in the state, and the denominator is the average value of all the taxpayer's real and tangible personal property owned or rented and used everywhere. ${ }^{191}$ All but five states with a property factor have adopted the MTC property rule. ${ }^{192}$

Income allocated under a formula may not fairly reflect the economic reality of taxpayer's business activities or factors of production. In order to accommodate these special situations, the MTC rules provide for a safe harbour provision, which allows taxpayers to petition for an alternative method of apportionment, including using separate accounting or removal/addition of a factor. ${ }^{193}$ In addition, MTC regulations provide special rules for eight different industries (see Table 5). ${ }^{194}$ The states generally follow these guidelines but provide for exceptions. ${ }^{195}$

185 California, Colorado, Illinois, Indiana, Maine, Mississippi, Oregon and Wisconsin have single sales factors with a throwback or throw-out rule. However, Georgia, lowa, Michigan, Nebraska, New York, Pennsylvania, South Carolina and Texas have single sales factors and no throwback or throw-out rule. See CCH Multistate Quick Answer Charts, Sales factors; Apportionment Formulas.

'If a state does not have a throwback rule in effect, 50-100 per cent of the profits of its resident corporations frequently will be what tax officials call "nowhere income", profit that is earned somewhere in the United States but not subject to tax by any state' (Mazerov 2003).

This rule applies to income from services, rental income from tangible or real property, income from the sale of real property, and income from intangibles.

For example, Alabama adds a provision to the MTC rules, which requires gross receipts from intangibles that constitute a principal source of business income to be sourced to the state in proportion to the property and payroll factors. Ala. Admin. Code r. 810-27-1-4-.17.

189 Compensation is deemed to be paid in the state if: the individual's service is performed entirely within the state; or the individual's service is performed both within and without the state, but the service performed without the state is incidental to the individual's service within the state; or some of the service is performed in the state and (1) the base of operations or, if there is no base of operations, the place from which the service is directed or controlled is in the state, or (2) the base of operations or the place from which the service is directed or controlled is not in any state in which some part of the service is performed, but the individual's residence is in the state. See MTC Reg. IV.13(c). See CCH Multistate Quick Answer Charts, Payroll Factors.

Property owned by the taxpayer is valued at its original cost. Property rented by the taxpayer is valued at eight times the net annual rental rate.

Connecticut, Louisiana, Mississippi, New Jersey and Rhode Island: owned property based on net book value not original cost and rented property all states value at eight times the annual rental rate. See CCH Multistate Quick Answer Charts, Property Factors.

See MTC Art. IV.18.

See MTC Reg. IV.18.

For example, Alaska uses an extractive factor consisting of total production of barrels of oil plus $1 / 6$ Mcf of natural gas for oil and gas production and pipeline transportation, while Florida allows an option for citrus growers to apportion income either through the equally-weighted three factor formula or a single sales formula. See CCH Multistate Quick Answer Charts, Special Formulas: Other Industries. 
Table 5 Multi-state compact apportionment formula rules for selected industries

\begin{tabular}{|c|c|}
\hline \multicolumn{2}{|c|}{ Multi-state compact apportionment formula rules for selected industries } \\
\hline Industry & Special rule \\
\hline Financial organisations & $\begin{array}{l}\text { Sales (gross receipts from many financial products), property (includes loans } \\
\text { and credit card receivables but does not include currency, deposits or foreclosed } \\
\text { property), payroll }\end{array}$ \\
\hline Airlines & $\begin{array}{l}\text { Transportation revenue (not including gains from sale of aircraft) + directly } \\
\text { attributable non-flight revenue, property (aircraft ready for flight apportioned by } \\
\text { ratio of in-state departures weighted by cost and value of aircraft), payroll (in- } \\
\text { flight personnel wages apportioned by ratio of in-state departures weighted by } \\
\text { cost and value of aircraft) }\end{array}$ \\
\hline $\begin{array}{l}\text { Construction contractors (for } \% \\
\text { completion accounting method) }\end{array}$ & Property, payroll, sales against $\%$ completed $\mathrm{x}$ contract amount \\
\hline Publishing & $\begin{array}{l}\text { Property (includes outer-jurisdictional property used valued by number of uplinks } \\
\text { and downlinks used to transmit and receive information from the state), payroll, } \\
\text { receipts (including gross receipts derived from advertising and the sale, rental or } \\
\text { other use of the taxpayer's customer lists or any portion thereof shall be } \\
\text { attributed to this state as determined by the taxpayer's 'circulation factor') }\end{array}$ \\
\hline Railroads & $\begin{array}{l}\text { Property (movable property is per diem and by miles); payroll (place of delivery } \\
\text { of service - must align with worker's income tax liability); sales (all of origination } \\
\text { and termination; and by track miles) }\end{array}$ \\
\hline TV and radio broadcasting & $\begin{array}{l}\text { Property (outer-jurisdictional property, e.g. satellites, excluded), gross receipts } \\
\text { (includes 'audience factor' for advertising), payroll }\end{array}$ \\
\hline Trucking companies & $\begin{array}{l}\text { Property (movable property is per mile); payroll (must align with mobile property } \\
\text { miles if services performed in and out of state); gross revenue (except hauling } \\
\text { freight, mail and express all of origination and termination intrastate sales and } \\
\text { interstate by miles); also de minimus nexus standard }\end{array}$ \\
\hline $\begin{array}{l}\text { Telecommunications and ancillary } \\
\text { service providers }\end{array}$ & $\begin{array}{l}\text { Property (outer-jurisdictional property, e.g. satellites, excluded); sales (services } \\
\text {-call-by-call attributed by origination and termination or origination or termination } \\
\text { plus in-state service address - and other telecommunication and ancillary } \\
\text { services - measured by place of primary use, etc.); payroll treated the same }\end{array}$ \\
\hline
\end{tabular}

\subsubsection{Administration, reporting and dispute resolution}

Each state levies and collects its own CIT revenue. Assessment appeals by taxpayers begin through state-level administrative appeal or court level and may accelerate through higher state courts with overall (discretionary) review at the federal Supreme Court level.

There is no automatic exchange of information procedure between the states and the federal government. ${ }^{196}$ However, most states require a copy of the taxpayer's annual federal return with the filing of the taxpayer's annual state return. Twenty-eight states require (mandatory reporting) or permit (elective reporting) a combined report, which includes reporting of taxable income by source jurisdiction from all business activities, either on a water's edge or worldwide basis, depending on state laws. Under federal law, taxpayers have the option of filing a consolidated return provided every member of the affiliated group consents. ${ }^{197} \mathrm{~A}$ consolidated return differs from a combined return in that consolidated taxable income is computed by calculating the separate taxable incomes of the members, aggregating them, and increasing or decreasing the result by items that are computed on a consolidated basis, such as ordinary and capital gains and losses. Thus, with consolidated returns the intragroup transactions (and associated transfer pricing of these transactions) are not eliminated. However, with combined reporting all intragroup transactions are eliminated in arriving at a total combined income/loss for the group. When the federal election to consolidate is made, some states accept a consolidated return for state income tax filing purposes as well. Apart from combined reporting, many states have enacted add-back statutes which disregard

\footnotetext{
196 Although there are information-sharing programmes in place, such as the Government Liaison Data Exchange Program, securing specific information on corporate tax liabilities from the Internal Revenue Service requires precise justification for information requests. See Griffith and Sawyer (2014). 
certain types of payment, such as interest on debt or royalties, made by a corporation to a related entity. However, WWCR (and certain water's edge elections for combined reporting ${ }^{198}$ ) avoids the need for add-back and other anti-abuse provisions because all intragroup transactions are eliminated.

\subsubsection{Conclusion}

The US approach to unitary taxation is marked by diversity. This lack of uniformity reflects the absence of tax harmonisation and also represents a broader struggle between states and the federal government to preserve revenue as well as protect state sovereignty. The lack of uniformity also represents the struggle to maintain a balance between economic development and a state's revenue needs for providing basic public services. ${ }^{199}$ However, it has been within this context that some states have devised effective solutions to reroute income back to the tax base through expanding the scope of tax base consolidation and reporting. WWCR based on the principle of unitary business and its resulting inclusion of income in the tax base from third jurisdictions is only applied in selected US states.

\section{Comparison and lessons learned from unitary tax approaches in federal and regional integrated markets}

Unitary taxation approaches from four federal integrated markets and one regional integrated market have been described in the previous section. This section compares these systems based on levels of tax base harmonisation, consolidation and apportionment as well as reporting requirements (see Tables 6 and 7, and Diagrams 8 and 9 below), and then extracts lessons learned for potential application of unitary taxation in regional economic communities.

\subsection{Tax jurisdiction}

In establishing tax jurisdiction, Canada, the EU CCCTB and Switzerland use PE rules which require some lasting physical presence, such as an office, a branch, a mine, an oil well, a farm, a timberland, a factory, a workshop or a warehouse. The US system also generally requires physical presence (but not twelve months of physical presence as does the OECD Model Convention in Article 5), and has enacted a federal law prohibiting a state from taxing income of corporations which only solicit orders for tangible goods in a state. However, a few states have enacted laws establishing tax jurisdiction over out-of-state corporations given the in-state presence of certain factors, such as gross receipts exceeding certain dollar amounts; even without these statutes, a few state courts have interpreted constitutional nexus more broadly than physical presence for taxing income from the sale of intangibles and services. In Argentina, under GIT, provinces have jurisdiction to tax gross receipts of a unitary business realised through a physical presence in the province, as well as receipts through independent agents or travelling salespersons.

\footnotetext{
198 These water's edge elections provide for inclusion of income from related foreign corporations with more than $20 \%$ of property, payroll and sales factors in the US as well as those in low- or no-tax jurisdictions.

199 Many commentators note that the balance is tipped towards economic development. For example, a study has found that the primary or secondary motive of creating special formulae has been to promote specific industries present within the state's borders (Anand and Sansing 2000).
} 


\subsection{Tax base harmonisation}

Only Argentina's GIT has a fully harmonised tax base. However, this is not surprising given that the tax base consists of gross receipts. For the CIT regimes, Canada and the EU CCCTB propose diverse tax credits (e.g. for investment) but require uniform depreciation allowances. Diversity of tax credits is controlled in the EU under the TFEU limitation on state aid, while Canada has a multitude of tax incentives among its provinces. Switzerland and the US allow both divergent credits and allowances for depreciation, but the deductions typically fall within narrow ranges either as stipulated by law in Switzerland or due to administrability reasons in the US.

\subsection{Tax base consolidation}

At the very least, each unitary taxation approach aggregates income from business activities conducted in separate taxing jurisdictions. Argentina, Canada and Switzerland do not aggregate the tax base beyond the legal entity. Within the corporate level, Argentina aggregates the tax base through a relationship test based on a unitary business principle. Thus, not all the income of a corporation would be aggregated for apportionment when there are multiple unitary businesses within one company. However, Canada and Switzerland do not apply this test and aggregate all income at the corporate level. The EU CCCTB and the US systems aggregate the tax base more broadly by combining the income from intercorporate entities which form a group. In the EU, this group is formed based on an ownership/control test; in the US, the group is formed by a relationship test and/or a control test.

In Diagram 8 below, Canada, Switzerland and some US states ${ }^{200}$ fall to the far left of the consolidation spectrum, with no cross-border merging of the tax base beyond the legal entity level. US states which allow for consolidated reporting as allowed at the US federal level lie at the third level of consolidation. Some loss transfer systems consolidate profit and loss after separate entity accounting without further aggregation of other tax attributes such as depreciation, while others, as is present in the US at the federal level and also allowed by many states, consolidate both profit and loss and tax attributes of an affiliated group. ${ }^{201}$ The CCCTB and the system of combined reporting present in over half the US states, however, fall on the far right of the aggregation spectrum because these systems involve a complete combination of income, expenses and tax attributes across the corporate group, disregarding all intra-group transactions.

\footnotetext{
200 Georgia, Louisiana, Maryland, Mississippi and Pennsylvania generally do not allow combined or consolidated return, and thus would not be included in the far right of the aggregation spectrum.

201 Australia, Denmark, Finland, France, Germany, Italy, Japan, Netherlands, the UK and the US employ systems along this spectrum. The fiscal unity system, employed in the Netherlands, functions on the basis of balance sheet consolidation. In this system, a national corporate group consolidates all balance sheet items and then adjusts for taxation. Under the proposed EU CCCTB, however, individual group members' profit and loss accounts are translated into tax accounts based on the common rules of the directive first, before being merged to produce the consolidated tax base which is then apportioned across all group members. Thus, the loss transfer system of the Netherlands involves consolidation at an earlier accounting stage, while the EU CCCTB involves consolidation of the tax base only.
} 


\section{Diagram 8 Comparison of corporate income tax systems by aggregation level}

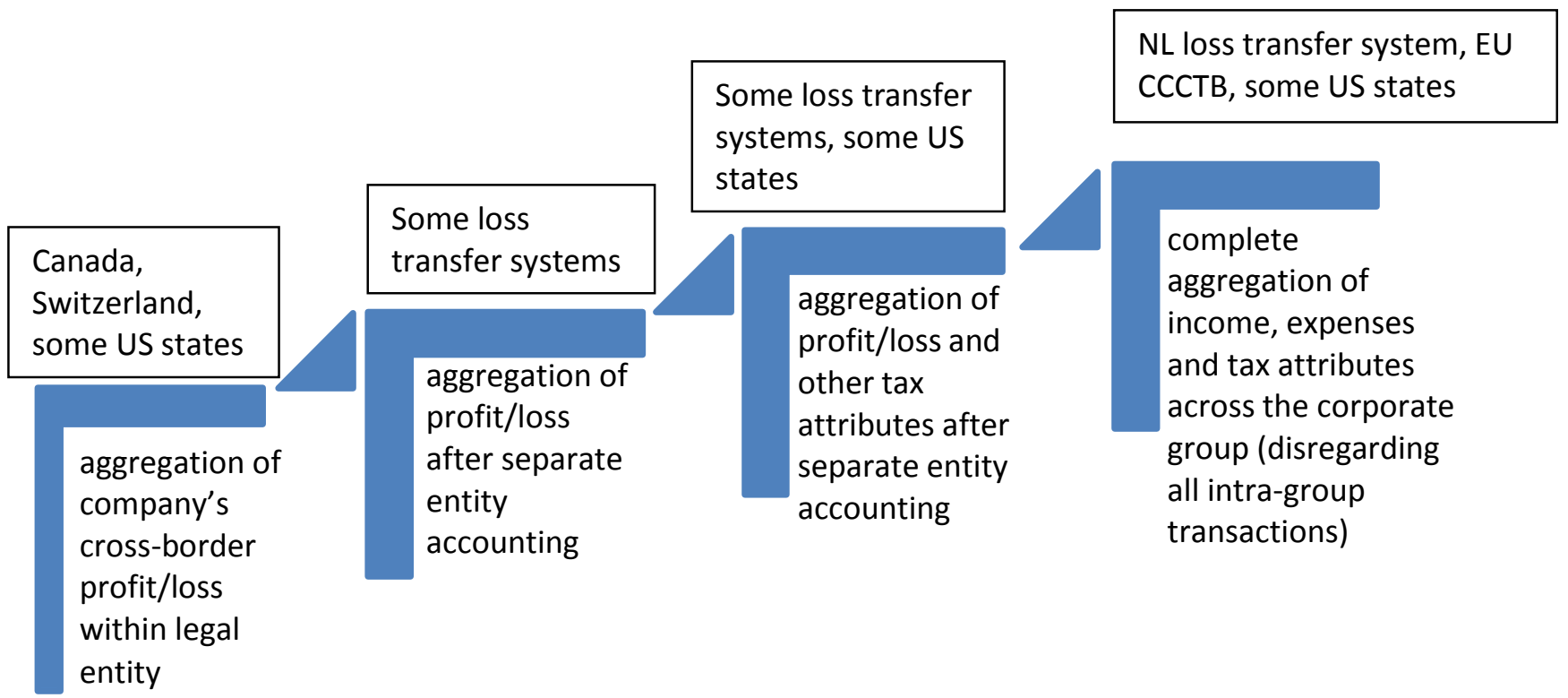

Of all the unitary taxation approaches, the US is the only system where certain states include income from third jurisdictions (apart from CFC and anti-abuse provisions under the EU CCCTB). These include the following methods: mandatory worldwide combination (as in the case of Alaska's oil, gas and pipelines sector); an optional method which excludes income from foreign affiliates with 80 per cent or more of payroll and property outside the US; or a default requirement with an option for a water's edge election, which includes income from certain types of corporations located in third jurisdictions.

Switzerland and the US draw a distinction between business and non-business income and only apportion the business income, while the EU CCCTB and Canada do not split the tax base before apportioning taxable income. ${ }^{202}$ (See Diagram 9 below.)

\subsection{Tax base apportionment and/or allocation}

The apportionment formula operates as a proxy for economic activity to split the tax base among jurisdictions (or in the case of the EU CCCTB among the group members and hence among the jurisdictions) which have an economic connection to the income of a corporation. Generally, the formulae strike a balance between production and consumption factors. The only formula which does not reflect this balance is the destination-based single sales factor, found in seventeen US states, with several more states transitioning to the destination-based single sales factor in the next three years.

For sales of tangible goods, the sales factors generally use a destination-based allocation rule, with the exception of Switzerland which sources sales at the place of production. The destination-based sales factors also generally include: a throwback rule which attributes sales to the jurisdiction of the last shipment or production where there is a destination jurisdiction with no taxable presence, or a throw-out rule where there is no group member present in the last identifiable location of shipment, or both. In the case of a throw-out, the CCCTB assigns the sale to the group members according to their respective asset and labour factors. 
For sales of services, the sales are generally sourced where the income-producing activity is performed. Under the US MTC rules, if the income-producing activity is performed in more than one state it is sourced in the state in which a greater proportion of the activity is performed, based on costs of performance. In Canada, if there is no PE where the service is rendered the sale is attributed to the PE of the person negotiating the contract for services. There is no special source rule for electronic services under the CCCTB.

The only labour factor which balances headcount with wages and salaries is the EU CCCTB. This balancing takes into account variations in labour costs among the EU MS. ${ }^{203}$ The other systems with payroll factors use wages and salaries and generally include all amounts paid for compensation of employee services, with the exception of five US states which do not include income paid to executive officers. In Canada the payroll factor includes wages and salaries paid for services that would normally be performed by employees of the corporation, but the US MTC rules only include compensation paid to employees. The EU CCCTB includes indirect employment in its payroll factor, while national law determines the definition of an employee.

The property factors in the US and EU CCCTB formulae only include real and tangible assets and are generally valued at original cost (under the CCCTB depreciable assets are valued at the average value throughout the year), and leased assets are valued at eight times the annual rental rate. Current assets, such as inventory, are included in the US property factor but not under the CCCTB. Under the Swiss system, only productive assets are included and are generally capitalised at 6 per cent. Under all the systems with property factors, intangible assets are excluded (with the exception of special formulae for the financial and insurance sectors).

\subsection{Reporting requirements}

All jurisdictions require annual consolidated filings which report income earned based on the level of tax base aggregation. This means that if only corporate-level income is aggregated among provinces (as is the case in Canada and Switzerland), the tax return must include details of the income earned by the single corporation (and branches) within all the provinces. There are two exceptions: Switzerland requires global income reporting, even though the tax base is only consolidated domestically; and some US states do not require combined reporting of income earned in other jurisdictions (including other US states), even though the tax base includes activities of a unitary business in other jurisdictions. As a result, in Switzerland taxpayers are required to provide complete details of entity-level worldwide income and capital, while in the US taxpayers are only required to report in-state income. This informational deficit may explain the increasing trend towards combined reporting among the US states.

\subsection{Lessons learned}

Each unitary taxation approach has developed in a particular political and economic context with varying attributes that enable each system to function properly. Therefore, at present there is no one-size-fits-all unitary taxation approach, and each system is established within its supporting political and economic union. Given this caveat, uniformity seems to be a key factor for the success of any unitary taxation approach, whether in the definition, consolidation or apportionment of the tax base. Uniform rules for accounting of income and expenses, as well as tax credits and allowances such as depreciation, eliminate differences in tax base determinations across jurisdictions. Furthermore, where the tax base is apportioned according to certain factors of production, such as property, payroll and sales, McLure argues, based on a mathematical analysis, that any formula apportioning income

203 See CCCTBIWPI047, p. 6. 
operates as an excise tax on each of the factors of production (McClure Jr. 1977). Thus, any variation of the rules for tax base determination, consolidation or apportionment creates a certain degree of distortion. ${ }^{204}$

Moreover, a high degree of variance increases the likelihood of exploitation of arbitrage opportunities and also results in higher compliance costs for taxpaying businesses both big and small. Uniform rules promote vertical equity by levelling the playing field among taxpayers with varying amounts of resources for tax planning. Moreover, uniform rules promote efficiency and tax neutrality goals, because location decisions are based on available market resources and potential return on investment rather than divergent rules for determining, consolidating and sharing the tax base. Finally, a lack of uniformity strains audit capacity of tax authorities and impedes enforcement of the tax system - particularly in developing countries.

The factors of the apportionment formula operate as proxies for economic activity to split the tax base among jurisdictions which have an economic connection to the income of a unitary business. Where a formula does not balance production and consumption aspects of how income is earned, the economic proxy value decreases and the sharing mechanism is less accurate. Thus, an apportionment formula should balance the supply side (either in the form of human or physical capital or both), and demand side (in the form of gross receipts of revenue).

This balancing of production and consumption factors in the apportionment formula also increases inter-jurisdictional equity. Although many jurisdictions may have robust consumer markets as well as manufacturing or service sectors, and would benefit equally from both types of production factors in an apportionment formula, less developed economies with smaller consumer markets or lower wage levels would capture less revenue under a balance weighted towards consumption or a payroll factor only determined by remuneration amounts. A single sales formula, now the trend in US states, represents this type of consumptionoriented sharing mechanism. This trend reflects more of an effort to promote economic development than an intent to design a formula as an accurate proxy for economic activity. However, the labour factor in the EU CCCTB, which balances the payroll factor between remuneration and headcount, promotes inter-jurisdictional equity because it takes into account different wage levels across EU MS. ${ }^{205}$

For taxpayers, clear and understandable rules increase certainty and decrease costs of compliance. As applied to unitary taxation approaches, simplicity in rules of consolidation should be balanced with flexibility, which allows for rules that accurately consolidate and apportion the tax base to reflect the economic substance of the income-producing activity. For example, entity-level consolidation aggregates the tax base of branches and the corporation across jurisdictions. Although this approach serves goals of simplicity by staying within the boundaries of the legal entity, it may not reflect the economic reality of the shared value inherent in a multinational corporate group. Moreover, consolidation of income based on corporate voting stock ownership may provide a definitive threshold for consolidation, but it may also consolidate more than necessary, combining unrelated business lines which lack economic integration. In this case, application of the unitary business principle, along with a voting stock ownership threshold as a secondary test, may be desirable.

Another important determination, which has consequences for the administrability/flexibility balance, is the valuation of and potential inclusion of intangible property in the property factor. Simplicity concerns have led many governments to exclude intangibles from the

\footnotetext{
204 In limited cases, income allocated under a formula may not fairly reflect the economic reality of taxpayer's business activities or factors of production. These special industries commonly include transportation, insurance and banking industries.

205 See CCCTBIWP\052ldoclen, pp. 6-7.
} 
property factor altogether, but this has led to special formula rules for financial institutions and insurance companies whose property is predominantly intangible/financial assets.

However, the presence of intangible property has increased dramatically with the advance of technological innovation and other types of intellectual property. Thus, intangibles should be a central consideration in the determination of the economic factors of production.

For governments, the most critical factor in ensuring the administrability of any system of unitary taxation is having enough information to assess a tax on income accurately. In this regard, a combined report of all income-producing activities under consolidation is essential. If consolidation is water's edge, the report should include income-producing activities of the unitary business in all jurisdictions within the water's edge territory. If consolidation is worldwide, the report should include income-producing activities of the unitary business in all jurisdictions worldwide. Moreover, WWCR may be necessary for jurisdictions that incorporate part of worldwide income under water's edge election rules or anti-abuse provisions. In any case, WWCR, regardless of the level of consolidation, gives tax administrations a better picture of the taxpayer's income-producing activities and removes informational barriers that would impede assessment and audit procedures. ${ }^{206}$

\subsection{Conclusion}

In summary, several observations emerge from this comparative analysis of existing unitary taxation approaches in federal and regional integrated markets:

- Unitary taxation systems reflect the structure and history of the economic and political unions upon which they are established.

- In terms of system design, uniform rules for determination, consolidation and apportionment of the tax base are recommended and special formulae rules should be restricted to specific industries.

- Apportionment formulae should balance production and consumption measures of economic activity.

- Combination of the tax base under the unitary business principle involves a facts and circumstances analysis and increases complexity of the system. However, this method of consolidation promotes equity concerns because it allows a corporate group to separate its tax base among varying unitary businesses (which may be subject to special apportionment formula rules).

- In order to administer a unitary tax system effectively, tax authorities should have complete information on income-producing activities of the entire unitary business. In this respect, a worldwide combined report is ideal.

The next section analyses potential applications of unitary approaches in regional integrated markets. As was the case in federal integrated markets, greater tax coordination is necessary in these regional economic communities to ensure the free movement of goods, services and capital. Moreover, once an open and integrated regional market for business has been established, an equitable sharing of the tax base allows all MS to benefit. In this regard, the feasibility of a unitary taxation approach will be explored in the context of the Association of Southeast Asian Nations (ASEAN), the East African Community (EAC), and Mercosur and Andean Community (CAN) in the Latin American region.

$206 \quad$ See McIntyre and Pomp (1995: 732): 'Form is elevated over substance when the income from the foreign activities of a unitary business are excluded from the combined report if they are conducted through a foreign corporation but are included in the combined report if they are conducted through a foreign branch of a domestic company'. 
Table 6 Comparison of systems of unitary taxation and formulary apportionment

\begin{tabular}{|c|c|c|c|c|c|}
\hline \multicolumn{6}{|c|}{ Comparison of systems of unitary taxation and formulary apportionment } \\
\hline \multirow{2}{*}{$\begin{array}{l}\text { Integrated } \\
\text { federal/ } \\
\text { regional } \\
\text { market }\end{array}$} & \multicolumn{2}{|c|}{ Tax base aggregation } & \multirow{2}{*}{$\begin{array}{l}\text { Inclusion of income } \\
\text { from third } \\
\text { jurisdictions: } \\
\text { worldwide or water's } \\
\text { edge }\end{array}$} & \multirow{2}{*}{$\begin{array}{l}\text { General } \\
\text { apportionment } \\
\text { formula }\end{array}$} & \multirow[t]{2}{*}{ Reporting requirements } \\
\hline & $\begin{array}{l}\text { Tax base } \\
\text { definition }\end{array}$ & $\begin{array}{l}\text { Tax base } \\
\text { consolidation }\end{array}$ & & & \\
\hline $\begin{array}{l}\text { Argentina } \\
\text { (GIT) }\end{array}$ & $\begin{array}{l}\text { Common tax base } \\
\text { definition }\end{array}$ & $\begin{array}{l}\text { Entity level based on } \\
\text { unitary business } \\
\text { activities }\end{array}$ & Water's edge & $\begin{array}{l}\text { Gross receipts + } \\
\text { expenses }\end{array}$ & Consolidated filing to the province of corporate headquarters \\
\hline $\begin{array}{l}\text { Canada } \\
\text { (CIT) }\end{array}$ & $\begin{array}{l}\text { Common tax base } \\
\text { definition with } \\
\text { divergent credits }\end{array}$ & $\begin{array}{l}\text { Entity level only (PEs } \\
\text { do not include } \\
\text { subsidiaries) }\end{array}$ & Water's edge & $\begin{array}{l}\text { Gross revenue + } \\
\text { payroll }\end{array}$ & $\begin{array}{l}\text { Consolidated filing for all provinces in which taxpayer has a } \\
\text { PE }\end{array}$ \\
\hline $\begin{array}{l}\text { EU - Proposed } \\
\text { CCCTB } \\
\text { (CIT) }\end{array}$ & $\begin{array}{l}\text { Common tax base } \\
\text { definition with } \\
\text { divergent credits }\end{array}$ & $\begin{array}{l}\text { Consolidation of } \\
\text { entities through } \\
\text { ownership test ( } 50 \% \\
\text { control }+75 \% \\
\text { ownership/rights to } \\
\text { profits) }\end{array}$ & Water's edge & $\begin{array}{l}\text { Gross revenue + } \\
\text { assets + labour } \\
\text { (labour }=\text { no. of } \\
\text { employees + wages) }\end{array}$ & Consolidated tax filing to principal tax authority \\
\hline $\begin{array}{l}\text { Switzerland } \\
\text { (CIT) }\end{array}$ & $\begin{array}{l}\text { Common tax base } \\
\text { definition with } \\
\text { divergent } \\
\text { allowances for } \\
\text { deductions and } \\
\text { tax credits }\end{array}$ & $\begin{array}{l}\text { Entity level only (PEs } \\
\text { do not include } \\
\text { subsidiaries) }\end{array}$ & Water's edge & $\begin{array}{l}\text { No general formula } \\
\text { - by industry; } \\
\text { uniform across } \\
\text { cantons; total } \\
\text { apportioned income } \\
\text { cannot exceed } \\
100 \%\end{array}$ & $\begin{array}{l}\text { Cantons require reporting on global income and capital; } \\
\text { profits of Swiss PEs of foreign corporations are determined } \\
\text { through separate accounting; the canton which is the main } \\
\text { tax residence of the taxpayer conducts assessment of the } \\
\text { taxpayer's tax base and apportions income among the main, } \\
\text { secondary and specific tax residences }\end{array}$ \\
\hline $\begin{array}{l}\text { United States } \\
\text { (CIT) }\end{array}$ & $\begin{array}{l}\text { Federal taxable } \\
\text { income starting } \\
\text { point with } \\
\text { divergent } \\
\text { allowances for } \\
\text { deductions and } \\
\text { tax credits }\end{array}$ & $\begin{array}{l}\text { Consolidation of } \\
\text { entities through control } \\
\text { test + relationship test } \\
\text { (unitary business) }\end{array}$ & $\begin{array}{l}\text { Mostly water's edge with } \\
\text { some worldwide } \\
\text { inclusion }\end{array}$ & $\begin{array}{l}\text { Variation of sales, } \\
\text { payroll and property }\end{array}$ & $\begin{array}{l}28 \text { states require or allow combined report; some states } \\
\text { require or allow consolidated return based on filing of a } \\
\text { federal consolidated return }\end{array}$ \\
\hline
\end{tabular}


Table 7 Comparison of apportionment formulae and factors

\begin{tabular}{|c|c|c|c|c|c|}
\hline \multicolumn{6}{|c|}{ Comparison of apportionment formulae and factors } \\
\hline \multirow{2}{*}{$\begin{array}{l}\text { Integrated } \\
\text { federal/ } \\
\text { regional } \\
\text { market }\end{array}$} & \multirow{2}{*}{$\begin{array}{l}\text { General } \\
\text { apportionment } \\
\text { formula }\end{array}$} & \multicolumn{2}{|l|}{ Gross revenue/receipts/sales factor } & \multirow[t]{2}{*}{ Payroll factor } & \multirow[t]{2}{*}{ Property factor } \\
\hline & & Goods & Services & & \\
\hline Argentina & $\begin{array}{l}\text { Gross receipts + } \\
\text { expenses }\end{array}$ & \multicolumn{4}{|c|}{ Total gross income and expenses in last closed balance sheet of previous calendar year; destination-based sales } \\
\hline Canada & $\begin{array}{l}\text { Gross revenue + } \\
\text { payroll }\end{array}$ & $\begin{array}{l}\text { Destination-based sales; throwback } \\
\text { rule to last shipment or place of } \\
\text { production; gross revenue does not } \\
\text { include: interest on bonds, } \\
\text { debentures, or mortgages; dividends } \\
\text { on shares of capital stock; or rents or } \\
\text { royalties from property that are not } \\
\text { part of the principal business } \\
\text { operations }\end{array}$ & $\begin{array}{l}\text { Attributed to the province in which they } \\
\text { are rendered; if no PE there, then the } \\
\text { PE of the person negotiating the } \\
\text { contract }\end{array}$ & $\begin{array}{l}\text { Wages and salaries as } \\
\text { well as fees to } \\
\text { individuals performing } \\
\text { same services as } \\
\text { employees }\end{array}$ & $\mathrm{N} / \mathrm{A}$ \\
\hline $\begin{array}{l}\text { EU - } \\
\text { Proposed } \\
\text { CCCTB }\end{array}$ & $\begin{array}{l}\text { Gross revenue }+ \\
\text { assets }+ \text { labour } \\
\text { (labour }=\text { no. of } \\
\text { employees }+ \\
\text { wages at equal } \\
\text { weights) }\end{array}$ & $\begin{array}{l}\text { Destination-based sales; throwback } \\
\text { rule which attributes the sales to the } \\
\text { jurisdiction of last shipment or } \\
\text { production where there is a non- } \\
\text { taxable destination jurisdiction; a } \\
\text { throw-out rule where there is no group } \\
\text { member present in the last identifiable } \\
\text { location of shipment; sales assigned to } \\
\text { group members according to the asset } \\
\text { and labour factors }\end{array}$ & $\begin{array}{l}\text { Services are deemed to take place } \\
\text { where they are physically carried out; } \\
\text { no source rule for electronically- } \\
\text { performed services }\end{array}$ & $\begin{array}{l}\text { Payroll = salaries, } \\
\text { wages, bonuses and all } \\
\text { other employee } \\
\text { compensation, including } \\
\text { related pension and } \\
\text { social security costs } \\
\text { borne by the employer; } \\
\text { should be equal to } \\
\text { amounts deducted by } \\
\text { the taxpayer within the } \\
\text { year }\end{array}$ & $\begin{array}{l}\text { Average value of all fixed } \\
\text { tangible assets owned, } \\
\text { rented or leased; } \\
\text { intangibles, current assets } \\
\text { such as inventory and } \\
\text { financial assets not } \\
\text { included in the asset factor }\end{array}$ \\
\hline Switzerland & \multicolumn{5}{|c|}{ NO GENERAL FORMULA } \\
\hline $\begin{array}{l}\text { United States } \\
\text { MTC/UDITPA }\end{array}$ & $\begin{array}{l}\text { Property, payroll } \\
\text { and sales }\end{array}$ & $\begin{array}{l}\text { Destination-based sales with a } \\
\text { throwback rule to last shipment point } \\
\text { where there is a non-taxable } \\
\text { destination jurisdiction; sourcing rules } \\
\text { for income from intangibles vary } \\
\text { among states }\end{array}$ & $\begin{array}{l}\text { Sales sourced where activity is } \\
\text { performed; if performed in more than } \\
\text { one state, sourced in the state in which } \\
\text { a greater proportion of the activity is } \\
\text { performed, based on costs of } \\
\text { performance }\end{array}$ & $\begin{array}{l}\text { Total amounts paid in } \\
\text { the state for employee } \\
\text { compensation }\end{array}$ & $\begin{array}{l}\text { Average value of the } \\
\text { taxpayer's real and } \\
\text { tangible personal property } \\
\text { owned or rented and used } \\
\text { in the state }\end{array}$ \\
\hline
\end{tabular}




\section{Diagram 9 Process comparison}
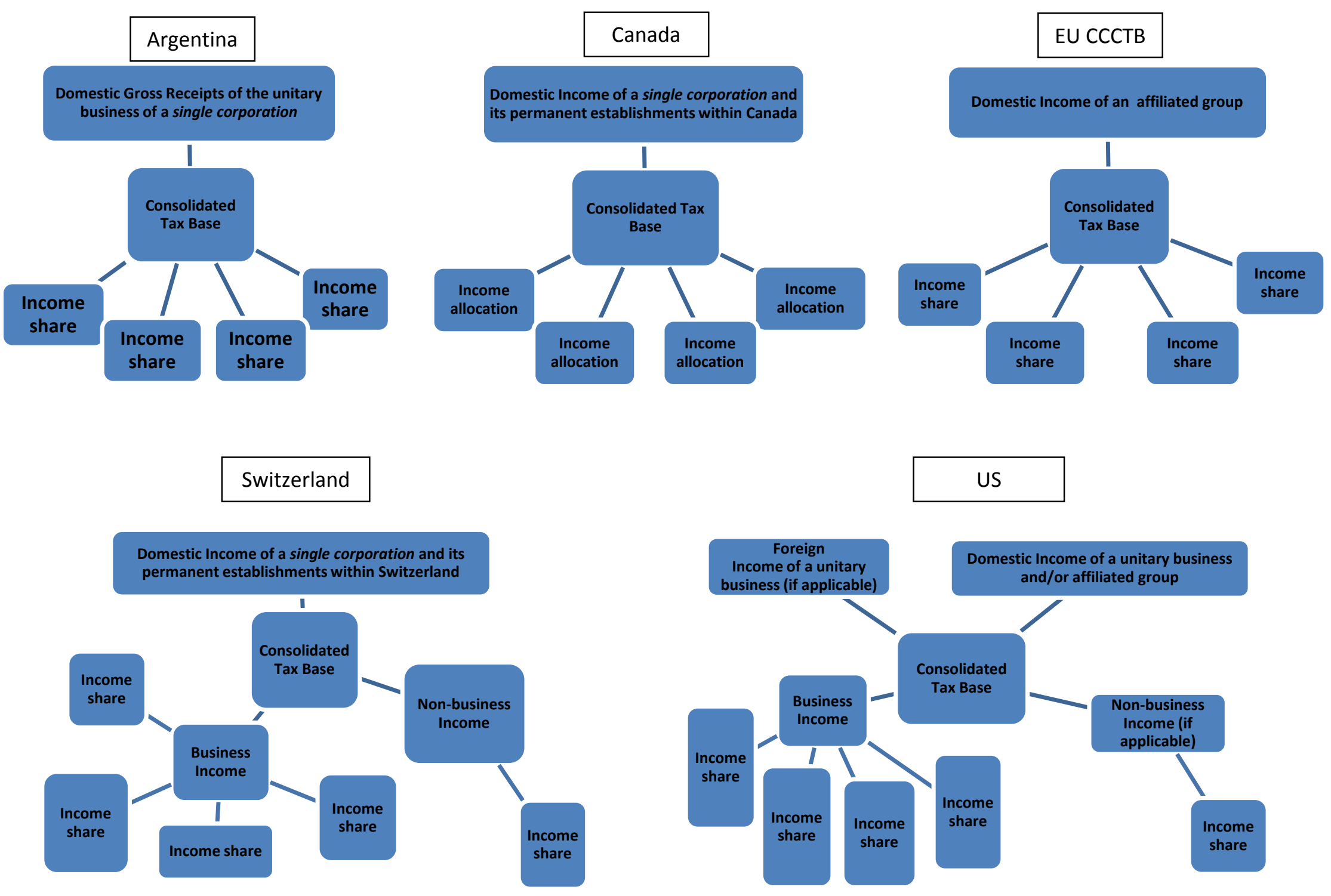


\section{Potential application of unitary tax approaches to regional integrated markets of the Global South}

\subsection{The ASEAN Region ${ }^{207}$}

\subsubsection{Political overview}

Founded in 1967, ASEAN now includes the following ten member countries: Brunei Darussalam, Cambodia, Indonesia, Lao PDR, Malaysia, Myanmar, Philippines, Singapore, Thailand and Vietnam. The combined population is 600 million, and the total GDP is US\$2 trillion. In 2007, ASEAN member countries agreed to establish a common market in the region called the ASEAN Economic Community (AEC), which will become operational in 2015. This agreement (the AEC Blueprint), calls for common measures to remove all barriers to hastening the establishment of the AEC, with the goal of making ASEAN a single market (ASEAN 2008). One of the vital issues in the AEC Blueprint is to eliminate tariff and non-tariff barriers to trade among member countries which prevent the free flow of goods, services, investment, skilled labour and capital (ASEAN 2008). (See Tables 9 and 10 at the end of this section for summaries of the taxes and TP rules in six ASEAN countries.)

The sole reference to corporate taxation is in Article 58 of the Blueprint - the commitment to complete bilateral agreements on avoidance of double taxation. Thus, at present the formation of the AEC is still in its preliminary stages, and the legal basis for tax harmonisation has yet to be established. The current emphasis within ASEAN has been on establishing the ASEAN Free Trade Area, with the creation of a customs union and economic community given a much longer time horizon. ${ }^{208}$ However, the adoption of unitary taxation approaches in the AEC should be considered as a way forward in economic integration. This section discusses the deemed profit methodology applied to PEs engaged in selected industries which has been adopted by Indonesia, and evaluates an alternative presumptive approach to curbing tax base erosion in the AEC.

\subsubsection{The deemed profits method}

To a certain extent, the taxation method of PEs under Indonesian Income Tax Law (ITL) is similar to unitary taxation, in that it does not look to individual transactions to determine the source of income. ${ }^{209}$ Under a unitary taxation system, a company conducts business activities and has branches scattered in different states of the same country. Under the Indonesian deemed profits method, the head office and its branches are located in two or more different tax jurisdictions. However, the method adopted by ITL is similar to apportionment of profits under unitary taxation. The principle adopted by both methods is based on a common understanding that attribution of profits to each branch depends on its contribution to the whole entity, except that under the deemed profits method the attribution of profits to a PE is determined by the source state without taking into account the profits of the company as a whole.

\footnotetext{
207 Rachmanto Surahmat, Section Author.

208 'ASEAN resembles the North American Free Trade Area between Canada, the United States and Mexico more than the EU, which has created a single internal market' (Cnossen 2013: 591).

209 The deemed profits and final tax regulations are governed by a ministerial decree based on Article 15 of the ITL. Under the provisions, the Minister of Finance is authorised to issue the method of taxation for selected taxpayers whose tax cannot be computed based on Article 16. Article 16 provides that taxable profits are derived by deducting allowable expenses from gross income.
} 
The concept does not recognise losses incurred by the company, and irrespective of losses that may incur the PE must pay income tax based on predetermined net profits. The method implies that the expenses associated with profits are also predetermined, including depreciation, interest, labour and other costs directly related to profits. Industries that are subject to deemed profits are international transport, trade representative offices, offshore drilling, construction and related services. (See Table 8.)

\section{Table 8 Deemed profits schedule}

\begin{tabular}{|l|l|l|}
\hline Industry & Deemed profits & Deemed expenses \\
\hline International transport: shipping and airline & $6 \%$ of outgoing freight & $94 \%$ \\
\hline Trade representative offices & $1 \%$ of export value & $99 \%$ \\
\hline Offshore drilling & $15 \%$ of sales & $85 \%$ \\
\hline Construction & $13.33 \%$ & $86.77 \%$ \\
\hline $\begin{array}{l}\text { Services related to construction: planning and } \\
\text { supervision of construction projects }\end{array}$ & $20 \%$ & $80 \%$ \\
\hline
\end{tabular}

From a double taxation agreement (DTA) perspective, the attribution of profits to a PE by the deemed profits method is in accordance with the OECD principle that taxation of a PE in the source state is without limitation. ${ }^{210}$ From the resident state viewpoint, however, the rate of profits may be different to the above figures. This will give rise to a double taxation problem, especially when the tax rates between the resident and source state are different. Thus, the adoption of unitary taxation should be dealt with multilaterally by all MS.

In addition to the deemed profits method, Indonesia also adopts a so-called final tax where resident companies, PEs, and foreign company representatives in the country are required to withhold tax from certain payments, including fees for construction, real estate rental payments and transfer gains, and interest on savings deposits and bonds. ${ }^{211}$ Unlike the deemed profits method, the final tax scheme determines CIT in advance as a percentage of the contract value. The net profit of companies engaged in industry that are taxed on final basis can be obtained by applying the applicable tax rate to any taxable income not already withheld.

\subsubsection{Unitary taxation and deemed profits}

Under unitary taxation methods, profits attributable to various parts of an entity are apportioned by allocating profits based on economic factors such as sales, payroll and profits. This apportionment can be done because the unitary taxation method requires consolidation. Unlike unitary taxation, the deemed profits method arbitrarily determines the rate of profit. In other words, the profit rate is determined unilaterally by the country where the PE is located, and the prime consideration is revenue. ${ }^{212}$ The deemed profits method does not recognise losses incurred, because profit is assigned as a certain percentage of turnover or sales. If the deemed profits method is to be adopted by the AEC as a basis for implementing a method of unitary taxation, a compromise on profit margins must be reached for the method to operate. From the perspective of transparency, unitary taxation is better than deemed profits because full disclosure of total profit is required; from the viewpoint of tax administration unitary taxation will improve compliance, which in the long run will ease the administrative burden.

\footnotetext{
210 OECD Model Tax Convention on Income and on Capital, para. 21.

211 See Income Tax Law Art. 4(2).

212 Most of the profit margins were determined in the early of 1970s based on agreement between the Indonesian Tax Authority (ITA) and the association of the industry. Table 8 demonstrates that the costs attributable to each industry vary widely, but there is no written justification for this.
} 
If unitary taxation is to be adopted by the AEC, the ITA must be prepared to give up a portion of its tax revenue. The deemed profits for PE (under Indonesian law) is similar to unitary taxation because under unitary taxation transparency and fair share of profits are crucial. Under the deemed profits method these factors are put aside, in addition to overlooking the right to claim losses. For this reason, rules on source income, cost apportionment and profit attribution must be well defined under the umbrella of a CCCTB agreement.

\subsubsection{Necessary steps towards a unitary taxation approach}

To enable unitary taxation to operate in the AEC, member countries would need to agree on a CCCTB. The fact that all member countries have agreed to the establishment of the AEC shows that the political will for economic integration exists, but this must be followed by action by all the members. In practice, this should come from the Ministries of Foreign Affairs and Finance. The agreement should establish a basis for determining the allocation of profits between the principal company and its branches in different countries. It should also prescribe a formula for the basis for apportionment. The deemed profits adopted by the ITL applicable to PEs engaged in selected industries can be considered as a starting point. Instead of applying a certain percentage of sales or turnover, attribution of profits should be done by adopting a formula which reflects the costs associated with profits in each country, which would constitute a first step in tax harmonisation. In this respect, the most urgent tax harmonisation issues that should be agreed upon are the following: the definition of profits attributable to a PE; deductible costs, including head office allocation; and a classification and depreciation schedule for capital assets.

\subsubsection{Conclusion}

Adoption of a unitary taxation approach in the AEC would further the realisation of the economic community, which in turn would enable the flow of goods and services in ASEAN. The primarily obstacles to realising this goal are the lack of tax harmonisation in and among many of the member countries and the resulting divergence in tax policy. A prime example is that ASEAN countries have different definitions of 'resident company' for tax purposes. Some countries define resident company to include the place of effective management, irrespective of the country of establishment (as is the case under Indonesian tax law).

Another obstacle lies in the differing economic niches of ASEAN countries. The Singaporean economy, for instance, relies heavily on financial trading and services, while Indonesia is a capital importer and has tremendous resources. If each country places national interest as its first priority, without considering the longer term advantages of creating a vibrant regional economy that would be in the collective interest, it will be impossible to implement a unitary approach to corporate income taxation. In the light of these challenges, the road towards unitary taxation in the AEC must be paved by compromise. Pending an agreement on a unitary taxation model, however, the AEC could consider the Indonesian presumptive taxation method of deemed profits as a basis for determining the rate of profits applied to PEs engaged in selected industries. 
Table 9 Summary of taxes in six ASEAN countries

\begin{tabular}{|c|c|c|c|c|c|c|}
\hline Tax Type & Indonesia & Singapore & Malaysia & Philippines & Thailand & Vietnam \\
\hline $\begin{array}{l}\text { Corporate } \\
\text { Income Tax }\end{array}$ & $\begin{array}{l}\text { - } 35 \% \\
\text { - } 30 \% \text { for listed } \\
\text { companies that have } \\
\text { at least } 40 \% \text { of paid } \\
\text { capital traded on the } \\
\text { stock exchange } \\
\text { - Branch profits tax: } \\
20 \% \\
\text { - Tax incentives are } \\
\text { granted: accelerated } \\
\text { depreciation, } 10 \text { year } \\
\text { loss carry-forward } \\
\text { (standard loss carry- } \\
\text { forward: } 5 \text { years), } \\
\text { investment allowance, } \\
\text { tax holiday for periods } \\
\text { of } 5 \text { to } 10 \text { years for } \\
\text { investment in pioneer } \\
\text { industries and subject } \\
\text { to certain criteria } \\
\text { - Selected industries } \\
\text { are taxed on deemed } \\
\text { profits basis, with the } \\
\text { following effective } \\
\text { rates: construction } \\
\text { (2\% to } 6 \% \text {, foreign } \\
\text { drilling company } \\
\text { (3.75\%) Non-resident } \\
\text { international shipping } \\
\text { companies and } \\
\text { airlines ( } 2.64 \%) \\
\text { - Withholding tax } 20 \% \\
\text { applies to dividends, } \\
\text { royalties, services } \\
\text { payment to non- } \\
\text { resident } \\
\text { Withholding tax rate is } \\
\text { reduced under tax } \\
\text { treaties } \\
\end{array}$ & $\begin{array}{ll}\text { - } & 17 \% \\
15 \% \text { withholding } \\
\text { applies to interest paid } \\
\text { to non-residents } \\
10 \% \text { withholding } \\
\text { applies to royalties } \\
\text { Dividend is not subject } \\
\text { to withholding tax } \\
17 \% \text { withholding is } \\
\text { imposed on payments } \\
\text { to non-residents for } \\
\text { services rendered in } \\
\text { Singapore } \\
\text { Tax incentives are } \\
\text { granted: tax holiday to } \\
\text { pioneer industries (up } \\
\text { to } 15 \text { years), under The } \\
\text { Development and } \\
\text { Expansion Incentive } \\
\text { (10 years and beyond } \\
\text { subject to certain } \\
\text { requirements), } \\
\text { investment allowance, } \\
\text { exemption of } \\
\text { withholding on } \\
\text { approved royalties, } \\
\text { enhanced deductions } \\
\text { under the Productivity } \\
\text { and Innovation Credit } \\
\text { Scheme, R\&D } \\
\text { incentive (deductions } \\
\text { of } 150 \% \text { for qualified } \\
\text { expenditure), Regional } \\
\text { Headquarters are } \\
\text { subject to lower tax } \\
\text { rate - } 0 \% \text { to } 15 \% \\
\text { Indefinite loss carry- } \\
\text { forward provided it } \\
\text { meets shareholding } \\
\text { test }\end{array}$ & $\begin{array}{ll}\text { - } & 25 \% \\
\text { - } & \text { Withholding tax rate: } \\
& 15 \% \text { (interest), } 10 \% \\
\text { (royalties), } 0 \% \\
\text { (dividends) } \\
\text { - } \quad \text { Unlimited loss carry- } \\
\text { forward } \\
\text { - } \quad \text { Tax incentives are } \\
\text { granted to } \\
\text { companies } \\
\text { established under } \\
\text { Labuan Offshore } \\
\text { Business Licence } \\
\text { Law, i.e. subject to } \\
\text { 3\% }\end{array}$ & $\begin{array}{ll}\text { - } & 30 \% \\
\text { - } & \text { Interest on domestic } \\
\text { local currency is } 20 \% \\
\text { - } & \text { Royalties are subject } \\
& \text { to withholding of } 20 \% \\
\text { - } & \text { Dividend is not subject } \\
\text { to withholding } \\
\text { - } \quad \text { Branch remittance tax } \\
\text { is } 15 \% \\
\text { - Minimum Corporate } \\
\text { Income Tax (MCIT) of } \\
2 \% \text { is imposed on } \\
\text { corporations subject to } \\
\text { certain criteria } \\
\text { - Tax incentive takes } \\
\text { the form of tax holiday } \\
\text { subject to certain } \\
\text { criteria } \\
\text { - Philippines source } \\
\text { income derived by } \\
\text { non-residents is taxed } \\
\text { at preferential rate } \\
\text { - Losses can be carried } \\
\text { forward for } 3 \text { years }\end{array}$ & $\begin{array}{l}\text { - } 20 \% \\
\text { - Withholding tax: } \\
\text { - dividends } 10 \% \\
\text { - interest } 15 \% \\
\text { - royalties: } 15 \% \\
\text { - Branch remittance tax : } \\
10 \% \\
\text { - Capital gains are } \\
\text { treated as ordinary } \\
\text { income } \\
\text { - } 5 \text { year loss carry- } \\
\text { forward } \\
\text { - Progressive rates of } \\
0 \%, 15 \% \text { and } 20 \% \\
\text { applied to locally } \\
\text { incorporated } \\
\text { companies with paid } \\
\text { up capital of not } \\
\text { more than THB } 5 \\
\text { million and revenue } \\
\text { not more than THB } \\
30 \text { million per year }\end{array}$ & $\begin{array}{l}\text { - } 25 \% \\
\text { - } \text { Branch tax rate - } 25 \% \\
\text { - Petroleum companies } \\
\text { re subject to tax } \\
\text { ranging from } 32 \% \text { to } \\
50 \% \\
\text { - } \text { Mining companies } \\
\text { engaged in exploiting } \\
\text { precious natural } \\
\text { resources are subject } \\
\text { to tax at a rate ranging } \\
\text { from } 40 \% \text { to } 50 \% \\
\text { - Withholding tax on } \\
\text { interest } 5 \% \\
\text { - Withholding tax on } \\
\text { royalties } 10 \% \\
\text { - } 5 \text { year loss carry- } \\
\text { forward } \\
\text { - Tax incentive is } \\
\text { granted in the form of } \\
\text { preferential rates of } \\
10 \% \text { or } 20 \% \text { subject to } \\
\text { certain criteria }\end{array}$ \\
\hline $\begin{array}{l}\text { Capital gains } \\
\text { tax }\end{array}$ & $\begin{array}{l}-0.1 \% \text { final withholding } \\
\text { tax is imposed on } \\
\text { proceeds of sales of } \\
\text { shares of listed }\end{array}$ & No capital gains tax & $\begin{array}{l}\text { - Real property gains tax } \\
\text { is } 15 \% \text { for property } \\
\text { held } 2 \text { years }\end{array}$ & $\begin{array}{l}\text { - Gains on the transfer of } \\
\text { land or building are } \\
\text { subject to } 6 \% \text { of the } \\
\text { selling price or fair }\end{array}$ & $\begin{array}{l}\text { Capital gains are treated } \\
\text { as ordinary income and } \\
\text { subject to CIT }\end{array}$ & $\begin{array}{l}\text { - Gains derived from the } \\
\text { sale of fixed assets are } \\
\text { taxed at normal rate }\end{array}$ \\
\hline
\end{tabular}




\begin{tabular}{|c|c|c|c|c|c|c|}
\hline Tax Type & Indonesia & Singapore & Malaysia & Philippines & Thailand & Vietnam \\
\hline & $\begin{array}{l}\text { companies; additional } \\
\text { rate of } 0.5 \% \text { is levied } \\
\text { on the shares value } \\
\text { after it is listed } \\
5 \% \text { tax is imposed on } \\
\text { the sales of shares of } \\
\text { an Indonesian } \\
\text { company held by } \\
\text { non-resident }\end{array}$ & & $\begin{array}{l}\text { - } 10 \% \text { rate applies for } \\
\text { property held for } 5 \\
\text { years, and } 0 \% \text { rate if } \\
\text { the alienation takes } \\
\text { place in the } 6^{\text {th }} \text { year } \\
\text { - Gains on the sale of } \\
\text { shares in real property } \\
\text { companies is taxed at } \\
\text { the rate of } 2 \% \text { of the } \\
\text { purchase price } \\
\text { - Trading losses can be } \\
\text { carried forward } \\
\text { indefinitely }\end{array}$ & $\begin{array}{l}\text { market value, } \\
\text { whichever is higher } \\
\text { - Gains from the sale of } \\
\text { shares of domestic } \\
\text { corporations not traded } \\
\text { in stock market is } \\
\text { subject to tax of } 5 \% \text { of } \\
\text { the net capital gain not } \\
\text { exceeding } P 100,000 \\
\text { and } 10 \% \text { on the excess } \\
\text { - Gains on the sale of } \\
\text { shares of listed } \\
\text { companies is subject to } \\
0.5 \% \text { of the gross } \\
\text { selling price } \\
\text { - Disposition of shares of } \\
\text { closely held companies } \\
\text { through initial public } \\
\text { offering, is taxed at the } \\
\text { rate of } 1 \%, 2 \% \text { or } 4 \% \text { of } \\
\text { the gross sale price }\end{array}$ & & $\begin{array}{l}\text { - Gains from the sale of } \\
\text { shares are taxed at the } \\
\text { rate of } 25 \% \\
\text { - Transfer of securities } \\
\text { by foreign investors are } \\
\text { subject to presumptive } \\
\text { tax of } 0.1 \% \text { of sale } \\
\text { proceeds }\end{array}$ \\
\hline $\begin{array}{l}\text { VAT/sales } \\
\text { tax }\end{array}$ & $\begin{array}{ll}- & \text { Standard rate of } 10 \% \\
\text { In addition to normal } \\
\text { VAT rate, goods that } \\
\text { fall under luxurious } \\
\text { category are subject } \\
\text { to Sales Tax on } \\
\text { Luxurious Goods } \\
\text { ranging from } 20 \% \text { to } \\
200 \% \\
\end{array}$ & GST 7\% & Sales tax 5-10\% & VAT $12 \%$ & VAT $7 \%$ & $\begin{array}{l}\text { VAT } 10 \% \\
\text { Certain types of goods } \\
\text { are subject to additional } \\
\text { consumption tax ranging } \\
\text { from } 10 \% \text { to } 70 \%\end{array}$ \\
\hline
\end{tabular}

Source: Ernst \& Young (2013) 
Table 10 Transfer pricing guidelines in six ASEAN countries

\begin{tabular}{|c|c|c|c|c|c|c|}
\hline & Indonesia & Singapore & Malaysia & Philippines & Thailand & Vietnam \\
\hline Effective date & 6 Sept 2010 & & 1 Jan 2009 & & & 6 June 2010 \\
\hline Location & $\begin{array}{l}\text { PER-43/PJ/2010 amended } \\
\text { with } \\
\text { PER-32/PJ/2011 }\end{array}$ & $\begin{array}{l}\text { Circulars issued by Internal } \\
\text { Revenue Service }\end{array}$ & $\begin{array}{l}\text { Section 140A of the ITA, } \\
1967\end{array}$ & $\begin{array}{l}\text { No official TP } \\
\text { Guidelines in place. } \\
\text { Draft in circulation }\end{array}$ & $\begin{array}{l}\text { PAW 113/2545 (DI 113), } \\
\text { issued in May } 2002\end{array}$ & $\begin{array}{l}\text { Law on tax } \\
\text { administration } 2006\end{array}$ \\
\hline $\begin{array}{l}\text { Requirement to } \\
\text { audit group global } \\
\text { consolidated basis } \\
\text { profit \& loss } \\
\text { statement }\end{array}$ & Negative & $\begin{array}{l}\text { TP guidelines adopt the } \\
\text { OECD Transfer Pricing } \\
\text { Guidelines } \\
\text { TP consultation process is } \\
\text { adopted to assess the level } \\
\text { of compliance with the TP } \\
\text { Guidelines }\end{array}$ & $\begin{array}{l}\text { TP guidelines issued in } \\
2012 \\
\text { Detailed documentation } \\
\text { requirements for tangible } \\
\text { goods, intragroup } \\
\text { services, intangible } \\
\text { property, financial } \\
\text { assistance and cost } \\
\text { contribution arrangements }\end{array}$ & None & $\begin{array}{l}\text { A list of } 10 \\
\text { documentation } \\
\text { requirements to justify } \\
\text { intercompany } \\
\text { transactions }\end{array}$ & $\begin{array}{l}\text { Prepare and submit } \\
\text { the mandatory TP } \\
\text { disclosure form } \\
\text { annually } \\
\text { Prepare and maintain } \\
\text { mandatory } \\
\text { contemporaneous TP } \\
\text { documentation }\end{array}$ \\
\hline $\begin{array}{l}\text { Provisions for } \\
\text { Advance Pricing } \\
\text { Agreements (APAs) }\end{array}$ & $\begin{array}{l}\text { APA is available under } \\
\text { Article 18(3a) of the } \\
\text { Income Tax Law }\end{array}$ & APA is available & $\begin{array}{l}\text { APA is available based on } \\
\text { Regulation: PU } 133 \text { (a) } \\
\text { Income Tax Rule }\end{array}$ & & & $\begin{array}{l}\text { APA regulation will be } \\
\text { adopted in the future }\end{array}$ \\
\hline $\begin{array}{l}\text { Provisions for } \\
\text { Transactional net } \\
\text { margin method } \\
\text { (TNMM) }\end{array}$ & $\begin{array}{l}\text { The adoption of TNMM is } \\
\text { limited to transactions } \\
\text { where one of the parties } \\
\text { provides special } \\
\text { contribution or one of the } \\
\text { parties engages in complex } \\
\text { and interconnected } \\
\text { transactions }\end{array}$ & & $\begin{array}{l}\text { TP method selection: } \\
\text { traditional over } \\
\text { transactional }\end{array}$ & & $\begin{array}{l}\text { Acceptable transfer } \\
\text { methods include CUP, } \\
\text { resale price method, the } \\
\text { cost-plus method, and } \\
\text { other internationally- } \\
\text { accepted methods }\end{array}$ & \\
\hline
\end{tabular}

Source: Ernst \& Young (2013) 


\subsection{The East African Community ${ }^{213}$}

\subsubsection{Political overview}

The East African Community $(\mathrm{EAC})$ is a regional economic intergovernmental organisation comprised of five East African nations: Burundi, Kenya, Rwanda, Tanzania and Uganda. ${ }^{214}$ The EAC has a total population of more than 130 million people, a land area of $1,820,000$ $\mathrm{km}^{2}$ and combined GDP of US $\$ 84.7$ billion. ${ }^{215}$ The Treaty for Establishment of the East African Community (EAC Treaty) was ratified in 2000 by the three original partner states (PS) - Kenya, Tanzania and Uganda. In 2007, Rwanda and Burundi acceded to the EAC Treaty and became full members of the community. The EAC was established with a vision of setting up a prosperous, competitive, secure, stable and politically-united East Africa, and providing a platform to 'widen and deepen economic, political, social and cultural integration in order to improve the quality of life of the people of East Africa through increased competitiveness, value added production, trade and investments' ${ }^{216}$ To this end, the EAC established a Customs Union in 2005 through the EAC Customs Union Protocol, ${ }^{217}$ and a Common Market in 2010 through the EAC Common Market Protocol. ${ }^{218}$ The Fourth Strategic Framework sets out plans for consolidation of the Customs Union and Common Market, establishment of the EAC Monetary Union, and foundational work for the EAC Political Federation in accordance with Article 5(2) of the EAC Treaty. ${ }^{219}$

Under Article 83 of the EAC Treaty, the PS resolve to 'harmonise their tax policies with a view to removing tax distortions in order to bring about a more efficient allocation of resources within the community'. ${ }^{220}$ Under the EAC Treaty, this tax harmonisation includes aligning investment incentives ${ }^{221}$ and avoiding double taxation. ${ }^{222}$ Unlike the EU treaty, which reserves taxation to the EU MS and even leaves the removal of double taxation to bilateral tax treaties between the EU MS, ${ }^{223}$ the EAC PS make a multilateral commitment in Article 32 of the Common Market Protocol, to 'progressively harmonise their tax policies and laws to remove tax distortions in order to facilitate the free movement of goods, services and capital and to promote investment within the Community'. ${ }^{224}$ According to Kenneth Bagamuhunda, EAC Director of Customs, tax harmonisation is an element that runs through all the integration processes of the EAC and is a key component of fiscal policy harmonisation necessary for macro-economic convergence. ${ }^{225}$

As part of the $2009 \mathrm{EAC/GTZ}$ programme, Support to the EAC integration process, a study on tax harmonisation was undertaken (Peterson 2010). The study assessed the national

\footnotetext{
213 Milly Isingoma Nalukwago, Section Author.

214 The EAC intergovernmental organisation headquarters are located in Arusha, Tanzania.

215 See EAC website, About EAC statistics, available at <http://www.eac.int>.

216 See EAC website, About EAC, Mission and Vision, available at

$<\mathrm{http}$ ://www.eac.int/index.php?option=com_content\&id=1\&Itemid=53> accessed 23 September 2013).

Protocol on the Establishment of the East African Customs Union (2 March 2004).

Protocol on the Establishment of the East African Community Common Market (20 November 2009).

EAC Development Strategy (2011/12-2015/16): Deepening and Accelerating Integration (August 2011); '[T]he Partner States undertake to establish among themselves and in accordance with the provisions of this Treaty, a Customs Union, a Common Market, subsequently a Monetary Union and ultimately a Political Federation in order to strengthen and regulate the industrial, commercial, infrastructural, cultural, social, political and other relations of the Partner States to the end that there shall be accelerated, harmonious and balanced development and sustained expansion of economic activities, the benefit of which shall be equitably shared' (EAC Treaty, Art. 5(2)).

$220 \quad$ EAC Treaty, Art. 83(2)(e).

$221 \quad$ EAC Treaty, Art. 80(1)(f).

$222 \quad$ EAC Treaty, Art. 80(1)(h).

223 See Treaty of Rome, Art. 220.

224 Common Market Protocol, Art. 32.

225 Kenneth Bagahumunda, presentation on the Status and Road Map of Tax Harmonisation in the EAC, available at: <https://www.wbginvestmentclimate.org/advisory-services/regulatory-simplification/business-taxation/upload/Statusand-Road-map-of-Tax-Harmonization-in-EAC-Kenneth-Bagamuhunda.pdf>
} 
taxation systems of all PS and made recommendations on VAT harmonisation, excise duties, personal income tax (PIT), corporate income tax (CIT) and administration and procedures harmonisation. Strategic recommendations of the study included enhancement of transparency and information exchange, completion and implementation of the EAC DTA, and harmonisation of company and profit taxation. The PIT and CIT recommendations of the study were the following:

- Review and harmonise all tax incentives in the CIT system, especially export processing zones (EPZ) and special economic zones (SEZ)

- Harmonise initial capital allowances of more than 50 per cent

- Treat capital gains from asset sales as normal profit but allow for inflation adjustment

- Harmonise the treatment of losses (carry-forward) including foreign losses

- Harmonise withholding taxes on dividends, interest payments, royalties and service fees

- Enact national laws and harmonise rules on TP and thin capitalisation in addition to general anti-avoidance clauses regarding profit shifting

- Develop an EAC Model Convention for DTAs with third party countries

- Create special units for international taxation and tax harmonisation in the Ministries of Finance and Revenue Authorities (Peterson 2010: 4).

Despite an overall lack of tax regime harmonisation and competing tax rights which present a challenge to private sector development (Ramah 2013; Mutsotso 2010), harmonisation of domestic taxes remains a priority with several important developments (East African Community 2011: 40,58). The EAC DTA was signed in November 2010; it was intended to come into force on 1 July 2011 but is still subject to ratification by the PS. Thus far, Rwanda has ratified the agreement and GIZ is following up ratification by the other four PS. In anticipation of ratification, regional training on the DTA has been undertaken.

A draft Code of Conduct against harmful taxation, similar to the EU non-binding instrument, was submitted to the EAC in a report prepared for the EAC secretariat by Birungyi Cephas Kagyenda (Kagyenda n.d.) and supported by GIZ. The study considered the indicators of harmful tax competition in the EAC (as identified by OECD) to include zero or low effective tax rates, lack of transparency and ineffective or lack of exchange of information, artificial definition of a tax base, state aid and subsidies, failure to adhere to international TP guidelines, and the existence of secrecy provisions. The Code of Conduct addresses issues such as: transparency of tax administration procedures; exchange of information to exclude restrictions caused by bank secrecy; review of laws that provide bank secrecy and anonymous debt instruments to facilitate effective exchange of information; negotiable tax rates or bases; review of exempt foreign source income for prevention of treaty abuse advance tax rulings; tax treaties with third countries; state aid and subsidies; and tax avoidance and evasion. Specifically, on the enforcement of international TP guidelines the report recommended that where subsidiaries of an MNE are present in more than one PS in the EAC, the relevant tax authorities should consider carrying out joint audits of the subsidiaries.

Currently, a regional Tax Procedure Code is under development with the support of the International Finance Corporation (IFC) of the World Bank working with the East African Revenue Authority Technical Committee (EARATC). Harmonisation of tax incentives is also ongoing with the support of the IFC/World Bank working with Revenue Authorities (RAs) through the EARATC. At the time of writing, an investor motivation survey and regional methodology on determination of tax foregone have been completed. Efforts to enhance mainstreaming exchange of information between EAC RAs include a workshop held in August 2012 in Arusha on the EAC exchange of information templates. At this workshop, the format of the templates was shared and recommendations were made to facilitate the adoption and ease of use of these templates. These exchange of information arrangements 
have been developed with the support of GIZ. One of the recommendations made was for the EAC PS to join the Global Forum on Transparency and Exchange of Information for Tax Purposes. Thus far, Uganda and Kenya have joined, in October 2012 and July 2010 respectively. The African Tax Administration Forum has also focused on international taxation in Africa through capacity-building and meetings of MNE and RA leadership.

The EAC region also has a Revenue Authorities Digital Data exchange (RADDEx) which is used for trade information exchange; this is currently being upgraded to include a centralised database housed at the EAC Secretariat. It is a software application and data exchange system that allows near-to-real time transmission of customs documentation to authorised public and private sector users that are working at key transit border posts and cities across the five countries in the EAC. RADDEx shortens cargo processing times and the number of officials needed to process cargo.

Although the EAC has publically committed to coordinate and harmonise tax rates and has in fact made initial harmonisation efforts, ${ }^{226}$ tax bases and rates largely remain divergent (see Table 11 below). Currently, the income from related transactions of transnational corporations is taxed under the TP guidelines embedded in the respective country's tax laws. TP guidelines in the region have been enacted in the respective tax laws of three countries, Kenya (2006), ${ }^{227}$ Tanzania (2004) ${ }^{228}$ and Uganda (2011) ${ }^{229}$. Rwanda and Burundi are still in the development stages. Of these guidelines, Kenya is closer to the requirement to submit consolidated global accounts for MNE. Provisions of APAs are not explored except in the case of Uganda, and sources highlight the lack of capacity. Use of comparable databases has also been found to be very minimal except in the case of Kenya, where Orbis is used. (See Table 12 below).

\subsubsection{Application of a unitary approach for the EAC}

As explained above, the current arm's length principle, which treats MNEs as if they were loose collections of separate entities operating in different countries, gives them the liberty to shift their profits around the globe to suit their tax affairs. Hence, unitary taxation would better reflect the economic reality of the modern corporate enterprise. The current international taxation principles were developed in the industrial age, yet we are now in a digital economy and valuation of intangibles is becoming a challenge. In the EAC there is still an inability to track and validate cross-border transactions, especially transactions involving services and intangibles as in the telecommunications sector. Additionally, many MNEs undertake business employing unique and hard-to-value intangible assets, which are charged to their group entities on bases that do not match the appropriate allocation of profits in accordance with value creation. Valuing these assets and appropriately allocating these profits requires highly skilled audit staff on specific cases which take a long time, which competes with pressure to deliver quick results in order to boost revenue. Most of the MNEs in the EAC are affiliates or branches with parent companies in developed countries, and some of them have a turnover larger than the GDP of the EAC. Furthermore, the available comparable databases such as Orbis do not provide local factors, which poses a challenge in the establishment of the arm's length price because conditions in the EAC, such as transport charges and infrastructure, differ.

It is thus important to establish whether the experience of federal systems, especially the US or the attempts in the EU, could be relevant to the EAC. As discussed earlier in the US and

\footnotetext{
226 The EAC development strategy for 2006-10 called for investment incentives to be harmonised by December 2007 and for fiscal policies to be harmonised by June 2008.

227 Income Tax Act, §18(3).

228 Income Tax Act, $\S 33$ (requiring that related party transactions be conducted at arm's length).

229 Income Tax Act, §90-91, cap 340. There are also transfer pricing regulations 2011 and transfer pricing practice note 2012.
} 
EU contexts, the allocation of taxable profits is necessary in an equitable sharing of the tax base among PS, as well as ensuring low or no barriers to the movement of goods, services and mobility of business activities.

However, as the US has no federal harmonisation law, and a resulting wide variety in multistate corporate income taxation, it may not offer similar conditions to the EAC. While the US has fifty states, the EAC has only five PS, making regional harmonisation and agreement on taxation matters easier. The EU CCCTB proposal for harmonised tax base consolidation and apportionment would be more appropriate as a model for the EAC since the corporate tax rules are currently being harmonised. The EAC has a uniform corporate tax rate of 30 per cent as of December 2013 across all the PS. Furthermore, the special industries for apportionment in the EU CCCTB proposal are similar to those in the EAC, including financial institutions, insurance, oil and gas, and ships and aircraft in international traffic. Similar special rules could thus easily apply in the EAC. However adoption of an EAC CCCTB based on the EU model would require further research within the EAC to establish the appropriate tax base definition, consolidation, allocation and apportionment according to EAC conditions.

Adoption of unitary taxation in the EAC would facilitate a reduction in the cost of compliance for MNEs, and simplify tax administration since there would be an agreed formula and full disclosure of income from MNEs with subsidiaries in the EAC. It would also preserve the sovereignty of the states to decide their own levels of taxation and public spending. This is an important factor for the EAC, where domestic taxation is still viewed as a national issue which should not be the subject of regional policy. The formulary approach could also ensure that the tax base would be equitably shared among PS based on economic factors of production and consumption. MNEs would also make a fair contribution as corporate citizens towards the costs of the public services provided by the country in which they do business. ${ }^{230}$

However, implementation of unitary taxation would present practical challenges, especially with determining the apportionment formula. A unitary taxation approach may also require a relatively uniform situation across countries to arrive at a reasonable result, and may not work well where the costs of people, property or sales vary significantly. Another challenging issue would be to apportion the tax base for companies dealing in e-commerce without PEs. Even proponents of unitary taxation, such as Picciotto, recognise that selecting and weighting factors in the allocation formula would be the most difficult issue for adoption of unitary taxation (Picciotto 2013). The exact economic impacts from a regional application of unitary taxation are unclear. Further research in this area is necessary.

As an initial step forward, submission of a combined and country-by-country report by MNEs with a business presence within the EAC would be an improvement to the existing TP guidelines. This report should include consolidated worldwide accounts for the company as a whole taking out all internal transfers; details of all entities forming the corporate groups and their relationships, as well as transactions between them; and data on physical assets and employees (by physical location), sales by destination and actual taxes paid in each country. Standardisation of this requirement could be facilitated by drawing up an agreed template for the report, benchmarking from other combined reporting requirements. This would facilitate determination of the production factors that could eventually help to establish an appropriate apportionment formula. This reporting requirement would also identify the number of MNEs in the region and their contribution to the individual states' GDP and the region as a whole.

230 This unfair distribution could be linked to the acceleration of foreign direct investment in the EAC region, which has increased from US $\$ 2,186 \mathrm{~m}$ in 2007 to US $\$ 3,847 \mathrm{~m}$ in 2012. See Table 13 below. Further research may be warranted. 
In the transition to a unitary approach, TP guidelines in the EAC should be harmonised (see Table 12 below) to include the clause in the UN Manual on Transfer Pricing that among documentation which the tax administration should request for a TP audit should be the group global consolidated basis profit and loss statement and ratio of taxpayers sales towards group global sales for five years (United Nations 2013: 318). This would give every national tax authority a clearer picture of the overall profits, and hence provide a check that the profits made and tax payable in the country concerned are not significantly out of line. This report would allow the EAC tax authorities to ensure that the profits declared and the tax payable by a transnational corporation are proportionate and appropriate to its activities in the country. As proposed in the draft Code of Conduct, joint audits should be considered for MNEs with subsidiaries in more than one PS. This would be a step towards implementing the country-by-country and combined report, since submitted records by the MNE would be audited together across all the PS.

The above improvements would necessitate skills development in the EAC PS national tax administrations. These unitary taxation alternatives should be included as options in capacity-building initiatives carried out by various development partners with experience in using a unitary approach, such as Canada, Switzerland and the US. In particular, a proposal has been presented to the EARATC and the EARACG by the Tax inspectors without Borders initiative of OECD. This proposed capacity-building programme deploys tax auditors on a demand basis, with a focus on providing expertise for matters involving international taxation issues. A recent feasibility study ${ }^{231}$ carried out by the Task Force on Tax and Development of the OECD highlighted recommendations and included the following observations: there is a high level of demand among tax administrations in developing countries for in-depth practical audit assistance from expert peers in other countries; and there is a need for provision of experts to enhance capacity not substitute it, for an appropriate framework to address programmes of bilateral assessment on tax matters and audit assessment which have developed organically on informal arrangements, and for a legal framework to protect the confidentiality of tax information. The types of tax matters for which assistance was sought included international tax matters such as TP, APAs, mutual agreement procedures, and joint audits.

\subsubsection{Conclusion}

Under unitary taxation EAC countries might still try to adapt their tax system to attract investment from MNEs, but this would have to be on the basis of favouring value-creating economic factors such as labour, assets and sales, or by lowering tax rates. This is very different from the avoidance incentives the current system gives countries to undermine other countries' tax systems. Adoption of unitary taxation could be facilitated by the regional coordination that is currently in place through EARATC, and ultimately the EARACG Forum, to create awareness among the RAs and thus political momentum for the governments to transition to a unitary taxation approach. The evolving mechanism to enable exchange of information on tax matters in the region through a memorandum of understanding can also be a facilitator. In the past decade there has been accelerated growth of private sector investments such as banking, hotels, manufacturing and construction, and at the same time national budgetary expenditure for infrastructure development. This convergence will highlight the need in the EAC region for a more cohesive and functional system of taxation. Unitary taxation may be a viable option, but more research and awareness-raising is needed. 231 See Task Force on Tax and Development website; OECD (June 2013), available at <http://www.oecd.org/ctp/tax-
global/taxinspectorswithoutbordershome.htm>. 
Table 11 Summary of taxes in the EAC 2012/13

\begin{tabular}{|c|c|c|c|c|c|}
\hline Tax & Burundi & Kenya & Rwanda & Tanzania & Uganda \\
\hline $\begin{array}{l}\text { Corporate } \\
\text { Income Tax }\end{array}$ & $\begin{array}{ll}- & 35 \% \\
\text { - } & \text { Zone Franche - tax } \\
\text { relief on certain } \\
\text { conditions } \\
\text { - } \quad \text { Export of non- } \\
\text { traditional products } \\
-17.5 \% \\
\text { Certain enterprises } \\
\text { exempt for } 10 \\
\text { years and then } \\
\text { taxed at } 15 \% \\
10 \% \text { reduction for } \\
\text { enterprises meeting } \\
\text { conditions and who } \\
\text { hire } 100 \\
\text { Burundians } \\
\text { Leasing and hire } \\
\text { purchase } \\
\text { enterprises exempt } \\
\text { for } 3 \text { years and } \\
20 \% \text { for next } 4 \\
\text { years }\end{array}$ & $\begin{array}{l}30 \% \text { (non-resident } 37.5 \% \text { ) } \\
\text { EPZ - } 10 \text { years } 0 \% \\
\text { Newly listed companies under the } \\
\text { capital Markets Act : } \\
20 \% \text { issued shares listed } 1-3 \text { years - } 27 \% \\
30 \% \text { issued shares listed } 1-5 \text { years - } 25 \% \\
40 \% \text { issued shares listed } 1-5 \text { years - } 20 \% \\
\text { Non-resident } \\
\text { Shipping operators - } 2.5 \% \text { of gross } \\
\text { Transmission of messages - } 5 \% \\
\text { Capital allowances } \\
\text { Qualifying investment exceeding USD230 } \\
\text { m outside Nairobi, Mombasa, and Kisumu } \\
\text { etc. - } 150 \% \\
\text { Other qualifying investment - } 100 \% \\
\text { Hotels/education buildings - } 50 \% \\
\text { Qualifying residential/ commercial building } \\
\text { - } 25 \% \text { Other qualifying buildings - 10\% (all } \\
\text { once only) } \\
\text { Farm works - } 100 \% \text { (once only) }\end{array}$ & $\begin{array}{l}30 \% \\
\text { FTZ - } 0 \% \text { indefinitely (exempt } \\
\text { from withholding tax and can } \\
\text { repatriate profits tax free) } \\
\text { Registered investors } \\
\text { Profit tax discount of } 2 \% \text { if } \\
\text { employs } 100-200 \text { Rwandans } \\
5 \% \text { if employs } 201-400 \\
6 \% \text { if employees between } 401- \\
900 \\
7 \% \text { if employs over } 900 \\
\text { Export tax discount } \\
\text { Bring to country revenue } \\
\text { USD } 3-5 \mathrm{~m} 3 \% \\
\text { USD } 5 \mathrm{~m}+5 \% \\
\text { Investment allowance registered } \\
\text { investor } \\
\text { Kigali - } 40 \% \\
\text { Outside Kigali - } 50 \%\end{array}$ & $\begin{array}{l}30 \% \\
\text { EPZ/SEZ - } 10 \text { year tax holiday } \\
\text { Newly listed company - 25\% } \\
\text { for } 3 \text { years } \\
\text { Capital Deductions } \\
\text { Buildings (straight line) } \\
\text { (agriculture / livestock/ } \\
\text { fisheries } 20 \% \text {; other } 5 \% \text { ) } \\
\text { Plant/machinery (reducing } \\
\text { balance class } 137.5 \% \text {, Class } \\
225 \% \text {, Class } 312.5 \% \text { ) } \\
\text { Mining and exploration/ } \\
\text { development - } 100 \% \\
\text { Agriculture - improvements/ } \\
\text { research and development - } \\
100 \%\end{array}$ & $\begin{array}{l}30 \% \\
\text { Exporters of } 80+\text { finished } \\
\text { consumer }+ \text { capital goods out } \\
\text { of EAC exempt for } 10 \text { years } \\
\text { Agro processing for } \\
\text { consumption in Uganda } \\
\text { exempt } \\
\text { Operators of aircrafts exempt } \\
\text { Education institutions exempt } \\
\text { Capital allowance } \\
\text { Industrial buildings/hotels } \\
(20 \% \text { initial }+5 \% \text { annual write } \\
\text { down allowance) } \\
\text { Plant and machinery (50/75\% } \\
\text { initial + annually on reducing } \\
\text { balance } 20 / 30 / 35 / 40 \%) \\
\text { Commercial buildings (straight } \\
\text { line } 5 \% \text { ) }\end{array}$ \\
\hline $\begin{array}{l}\text { Treatment of } \\
\text { goods in SEZ } \\
\text { EPZ under } \\
\text { the Single } \\
\text { Customs } \\
\text { Territory } \\
\text { (SCT) }\end{array}$ & \multicolumn{5}{|c|}{$\begin{array}{l}\text { Under the SCT } \\
\text { - Goods destined into SEZs or EPZs shall be entered into the country of destination } \\
\text { - } \quad \text { Transfer of goods to SEZ or EPZ in PS shall be covered under regional single customs bond guarantee framework } \\
\text { - Import of goods from an EPZ or SEZ in the SCT to a PS in the SCT shall be treated in accordance with the protocol on the customs union }\end{array}$} \\
\hline $\begin{array}{l}\text { Capital gains } \\
\text { tax }\end{array}$ & $35 \%$ & Suspended in 1985 & $\begin{array}{l}\text { Taxed on business profit } \\
\text { (none on private property) }\end{array}$ & $\begin{array}{l}30 \% \text { (individual } 10 \% \text { for } \\
\text { Tanzanian asset) }\end{array}$ & $30 \%$ \\
\hline VAT rate & $18 \%$ & $\begin{array}{l}16 \% \\
12 \% \text { supply and import of electricity supply and } \\
\text { fuel oils }\end{array}$ & $\begin{array}{l}18 \% \\
\text { Investors qualify for } \\
\text { exemption on imported } \\
\text { capital goods }\end{array}$ & $18 \%$ & $18 \%$ \\
\hline
\end{tabular}

Sources: EAC respective country's tax laws; EAC secretariat 
Table 12 Transfer pricing guidelines in the EAC region

\begin{tabular}{|c|c|c|c|c|c|}
\hline Area & Burundi & Kenya & Rwanda & Tanzania & Uganda \\
\hline Effective date & & 1 July 2006 & & 2004 & 1 July 2011 \\
\hline Location & & Section 18(3) of the Income Tax Act (ITA) & & $\begin{array}{l}\text { S } 33 \text { of the Income Tax Act requires that any } \\
\text { arrangement between related parties must } \\
\text { be conducted at arm's length }\end{array}$ & $\begin{array}{l}\text { s.90 and S. } 91 \text { of the Income Tax Act cap } \\
340 \\
\text { Transfer pricing regulations } 2011 \text { and } \\
\text { transfer pricing practice note } 2012\end{array}$ \\
\hline $\begin{array}{l}\text { Requirement to } \\
\text { audit group } \\
\text { global } \\
\text { consolidated } \\
\text { basis profit \& } \\
\text { loss statement }\end{array}$ & $\begin{array}{l}\text { No TP } \\
\text { guidelines as } \\
\text { yet }\end{array}$ & $\begin{array}{l}\text { KRA released a form (appendix to tax return) } \\
\text { where taxpayers should disclose details of } \\
\text { related party transactions such as global } \\
\text { organisational structure of the enterprise }\end{array}$ & $\begin{array}{l}\text { No TP } \\
\text { guidelines as } \\
\text { yet }\end{array}$ & $\begin{array}{l}\text { Description and amounts of related party } \\
\text { transactions are required to be summarised } \\
\text { and submitted with the tax return. }\end{array}$ & $\begin{array}{l}\text { Taxpayer not required to submit } \\
\text { disclosures to URA on an annual basis but } \\
\text { expected to keep all information relating to } \\
\text { TP policies and provide it on request. } \\
\text { Types of information to be disclosed have } \\
\text { not been provided for }\end{array}$ \\
\hline $\begin{array}{l}\text { Provisions for } \\
\text { Advance Pricing } \\
\text { Agreements } \\
\text { (APAs) }\end{array}$ & & $\begin{array}{l}\text { No APAs available however a taxpayer may } \\
\text { seek a non-binding opinion from the KRA on } \\
\text { interpretation or administration of tax } \\
\text { provisions }\end{array}$ & & $\begin{array}{l}\text { APA provided for in the Income tax } \\
\text { regulations but no APAs available as yet. A } \\
\text { company may apply to TRA for a private } \\
\text { ruling }\end{array}$ & $\begin{array}{l}\text { APAs are available, no options specified } \\
\text { as yet but a request and a draft agreement } \\
\text { must be made to URA which may then } \\
\text { accept it, modify it or reject it }\end{array}$ \\
\hline $\begin{array}{l}\text { Provisions for } \\
\text { Transnational } \\
\text { net margin } \\
\text { method (TNMM) }\end{array}$ & & $\begin{array}{l}\text { TP methods outlined in OECD Guidelines are } \\
\text { acceptable; however commissioner may } \\
\text { prescribe other methods. } \\
\text { Chapter } 4 \text { of the TP rules states that taxpayer } \\
\text { may choose the most appropriate method } \\
\text { 'Best method' rule applies }\end{array}$ & & $\begin{array}{l}\text { No guidance given by TRA so the OECD } \\
\text { Guidelines are used as the norm }\end{array}$ & $\begin{array}{l}\text { TP methods outlined in OECD Guidelines } \\
\text { are acceptable. There is no priority and no } \\
\text { best method rule has been laid out }\end{array}$ \\
\hline $\begin{array}{l}\text { What databases } \\
\text { are used as } \\
\text { comparable? }\end{array}$ & & $\begin{array}{l}\text { KRA expressed a preference for local } \\
\text { comparable databases where available. } \\
\text { However is currently using Orbis }\end{array}$ & & No known databases used as comparable & No known databases used as comparable \\
\hline Recoveries & & $\begin{array}{l}\text { Assessments of up to USD } 25 \text { million have so } \\
\text { far been raised. Built capacity and it is now } \\
\text { mandatory that every audit report must } \\
\text { incorporate a report on findings on taxpayer } \\
\text { TP activities }\end{array}$ & & $\begin{array}{l}\text { Tax law relating to TP and related party } \\
\text { transactions is relatively underdeveloped } \\
\text { thus expectations of TRA with regards to } \\
\text { related party transactions are different from } \\
\text { one case to another. This creates a degree } \\
\text { of unpredictability with regards to potential } \\
\text { tax costs. }\end{array}$ & $\begin{array}{l}\text { Regulations are still new and } 2012 / 13 \mathrm{FY} \\
\text { is when taxpayers are expected to have } \\
\text { TP documentation in place }\end{array}$ \\
\hline
\end{tabular}

Sources: KPMG, Global Transfer Pricing Review; Uganda, Kenya, Tanzania tax laws.

Table 13 Foreign direct investment flows to the EAC region in US\$ million

\begin{tabular}{|c|c|c|c|c|c|c|}
\hline Country & 2007 & 2008 & 2009 & 2010 & 2011 & 2012 \\
\hline Burundi & 1 & 4 & 0 & 1 & 3 & $\overline{1}$ \\
\hline Kenya & 729 & 96 & 115 & 178 & 335 & 259 \\
\hline Rwanda & 82 & 103 & 119 & 42 & 106 & 160 \\
\hline Tanzania & 582 & 1383 & 953 & 1813 & 1229 & 1706 \\
\hline Uganda & 792 & 729 & 842 & 544 & 894 & 1721 \\
\hline Total & 2,186 & & & & & 3,847 \\
\hline
\end{tabular}

Source: United Nations Conference on Trade \& Development (UNCTAD), World Investment Report 2013 


\subsection{Latin America - Mercosur and the Andean Community ${ }^{232}$}

Although Latin America and the Caribbean has several regional economic communities, such as the Caribbean Community (CARICOM) ${ }^{233}$ and Central American Common Market/Central American Integration System (CACM/SICA), ${ }^{234}$ Andean Community (CAN) and Mercosur represent significant markets and countries in terms of trade flow and foreign investment. Furthermore, Mercosur and CAN have reached a higher level of economic and political integration and proximity which justify the analysis of these two regional markets in a more detailed way. The following subsections will address the origins, structure and current status of Mercosur and CAN, in order to support further discussion of the feasibility of adoption of a unitary taxation approach in the region.

\subsubsection{Mercosur: historical background (LAFTA and LAIA)}

The integration process in Latin America was initiated by the Latin American Free Trade Association (LAFTA), established in 1960 by eleven country members: Argentina, Bolivia, Brazil, Chile, Colombia, Ecuador, Mexico, Paraguay, Peru, Uruguay, and Venezuela. However, LAFTA was an inflexible integration treaty and would not allow for bilateral or other types of internal arrangements, and for this reason it did not work properly. The same eleven LAFTA countries then established the Latin American Integration Association (LAIA) in its place. LAIA presents a flexible framework, allowing a wide range of agreements between country members and between members and non-members in the region, and also provides easy access for other countries to join the bloc. There are few restrictions to third party agreements with country members, except for trade treaties negotiated with developed countries.

Under the LAIA framework, Brazil, Argentina, Paraguay, and Uruguay negotiated the Asunción Treaty, which established Mercosur. ${ }^{235}$ Mercosur has its headquarters in Montevideo, Uruguay. After that, other treaties were negotiated between the four countries to establish a more stable framework, including a dispute resolution mechanism. ${ }^{236}$ The population of the bloc is approximately 280 million; it has a land area of $12,780,000 \mathrm{~km}^{2}$, and a combined GDP of approximately US $\$ 3,159$ billion (80 per cent of South American GDP).237

In the first decade of its establishment Mercosur made impressive progress. The country members created a customs union by applying the Mercosur Common External Tariff (TEC) to all non-member countries (the TEC came into force in 1995). Several Mercosur institutions were developed in order to build a formal structure to become operative, and to solve problems that are typical to common markets such as rules of origin and the most favoured nation principle. ${ }^{238}$ However, due to economic and political changes in the region, the bloc did not develop the way the founding countries had planned at the beginning. Despite these challenges, in 2007 the Mercosur Parliament was inaugurated, and in 2010 a

\footnotetext{
232 Marcos Aurélio Pereira Valadão, Section Author.

233 CARICOM member states: Antigua and Barbuda, The Bahamas, Barbados, Belize, Dominica, Grenada, Guyana, Haiti, Jamaica, Montserrat, Saint Lucia, St. Kitts and Nevis, St. Vincent and the Grenadines, Suriname, Trinidad and Tobago; CARICOM Associate Members: Anguilla, Bermuda, British Virgin Islands, Cayman Islands, Turks and Caicos Islands.

234 CACM member states: Costa Rica, El Salvador, Guatemala, Honduras, and Nicaragua; SICA member states: Belize, Costa Rica, El Salvador, Guatemala, Honduras, Nicaragua, Panamá, Dominican Republic.

235 The treaty established the Mercado Comun de la Sur; it was signed in March 1991, and came into force in November 1991.

236 See Valadão (2009: 211). The 2002 - Olivos Protocol on Dispute Settlement, which created a Permanent Tribunal (arbitral) as well as a post-decision control mechanism for Mercosur, was approved in 2002. For other constituent Mercosur treaties see <http://www.mercosur.int/t generic.jsp?contentid=4002\&site $=1 \&$ channel=secretaria\&seccion $=3>$ (text in Portuguese and Spanish).

237 Source: World Bank, at <http://data.worldbank.org/indicator/NY.GDP.MKTP.CD>, and <http://unstats.un.org/unsd/demographic/products/dyb/dyb2007/Table03.pdf>.

238 Valadão (2009: 212). Mercosur experienced a big expansion in the 1990s, averaging 19 per cent a year, almost three times higher than the rate of growth of their world trade (Pastor 2001).
} 
Common Customs Code was approved by the MS. Venezuela joined Mercosur as a full member in 2012, but in the same year Paraguay was suspended and the declaration to incorporate Bolivia was approved (the final step for accession). Currently Chile, Bolivia, Peru, Colombia and Ecuador enjoy the status of associated countries. ${ }^{239}$

The Common Market Council (CMC) of Mercosur serves as the political decision-making body and is the highest level group. CMC issues decisions that are binding on member countries. The Common Market Group (GMC) is the executive board; its main role is to implement and regulate the decisions adopted by the $\mathrm{CMC}$, and in this capacity issues resolutions. The Mercosur Trade Commission (CCM) organises consultations and also conducts dispute resolution proceedings. The CCM issues directives and proposals, the first being mandatory. These three Mercosur commissions have the capacity to make decisions. The Mercosur Parliament (formed by eighteen members per country), which replaced the Joint Parliamentary Group (CPC), is a consultative body and is now responsible for legislation harmonisation. The Economic and Social Consultative Forum (FCES) serves as a consulting body to the GMC, and was established as the channel through which civil society can participate in Mercosur. The administrative body is the Mercosur Secretariat (SM); this is responsible for administrative tasks, documenting all meetings, for the official bulletin and logistics, including technical assistance to all Mercosur institutions.

The most important achievement of Mercosur to date is the Common External Tariff (TEC) schedule. Most of the countries deal with tariff as a regular tax, and as a result tariffs are administered by the national revenue agencies. Mercosur treaties include many dispositions regarding tariffs (and other commercial barriers) and for harmonisation of economic policy, but are not very inclusive for other types of taxes. There is a provision on national treatment principle (Art. 7 of the Asunción Treaty), and a very broad disposition as a compromise for harmonisation of legislation that may strengthen the integration process (Art. 1, par. 6, of the Asunción Treaty). Although there is some academic work dealing with tax harmonisation in the region, there is no determination in the Mercosur norms (treaties, protocols, etc.) pointing to such a process (see, e.g., Filho and Catão (2001); Saldanha (2008); Peres (2002: 139149).

In regard to consumption taxes, all five countries have adopted VAT (the Brazilian VAT system is highly complex). In terms of income tax, all countries of the bloc assess an income tax on individuals and enterprises. Because the harmonisation of income and capital taxes is the last step for tax system harmonisation in a process of economic integration, harmonisation of direct taxes is not a current priority in the region. Indeed, tax harmonisation is not among the current concerns of the Mercosur countries, despite the fact that investment protection measures were adopted by the bloc (Barreix and Villela 2003: 77-99). However, for some aspects of CIT, such as TP rules, similar regulations are recommended (Barreix and Villela 2003: 76).

\subsubsection{Mercosur: current status and perspectives}

In the first decade of this century, the Mercosur integration process has been challenged by world transformation and global trends, such as the Free Trade Area of the Americas (FTAA) and US bilateral trade agreements, and more recently the global economic crisis. However, it has been affirmed that: 'there are economic and non-economic factors that are pushing the region to a position where economic and trade integration will be easier in the future. When economic and trade integration will be accomplished, however, is a question yet to be answered' (Valadão 2009: 220). Recent indications of gaining momentum can be seen in the Venezuela adhesion, the imminent Bolivia integration, and progress in the trade agreement

239 See $<$ http://www.mercosul.gov.br/> for more details (texts in Portuguese). 
between the EU and Mercosur, which has been under negotiation for the past fourteen years.

On the other hand, Eduardo Quintanilla Ballivián has noted:

$[T]$ he weakening of the traditional axis of regional integration of South America: the CAN, due to political and economic disparities among its member states, and the MERCOSUR, mainly due to the economic crisis and their large economic imbalances, as well as the failure of the proposal of economic liberalism to promote social and sustainable economic development, a new Latin American regionalism has started growing, on the common basis of understanding commerce and trade, as an instrument for political integration, rather than a final aim.

Under this new vision, in December 2004, MERCOSUR and the CAN signed a reciprocal associate-member status agreement and issued the Cusco Declaration stating that that they would create a political South American Community of Nations, invoking Bolivar's dream, noting its final aim to promote the unification of all Latin America. In 2007, the original name of the union was changed to the current one, the Union of South American Nations (UNASUR), with initial priorities at the economic level on infrastructure, energy and defense, but that has proven an important advance in political cohesion in crucial momentums in the region, such as the political crisis that took place in Bolivia, in 2008, the crisis between Colombia and Venezuela on the same year, and in Ecuador in 2010.

(Quintanilla Ballivián 2013: 3A-23)

\subsubsection{Mercosur: country-by-country analysis ${ }^{240}$}

This subsection addresses the tax system of the Mercosur countries, with a focus on income taxation and TP issues (social contributions, payroll taxes and other particular types of taxes levied by state or local governments are not considered here). All countries of the bloc have tax incentive schemes for some sector or operations which are not considered here either.

\section{Argentina}

Argentina is a federation, with a tax system that allows for provinces and local governments to impose taxes subject to limitations. VAT is levied by the central government on all residents and non-residents (through a representative), which must register if they perform taxable transactions in Argentina, at a standard tax rate of 21 per cent. The federal government also levies a net wealth tax (1 per cent for companies, and 1.25 per cent top rate for individuals), which is progressive. Argentina does not levy inheritance or gift taxes at the federal level. ${ }^{241}$ Excise taxes are levied on some goods and services (non-VAT type) with a top tax rate of 60 per cent. There are also other minor local taxes. The country assesses CIT on a worldwide basis ( 35 per cent rate for both resident and non-resident companies, but the latter are exempt from income tax derived from capital gains on sale of shares in resident companies). Under CIT, consolidation is not applicable.

\footnotetext{
240 Sources for this section: Esteban (2010); Barreix and Villela (2003); IBFD database <www.ibfd.com>. For a general overview of tax systems of Latin American countries see González et al. (2009: 121-142).

241 The sole case is the Buenos Aires province that levies inheritance and gift tax that applies to residents in the province (on worldwide basis) and to assets located in the province owned by non-residents.
} 
Argentina has adopted anti-avoidance rules for TP (see Table 15 below), thin capitalisation, and CFCs. As for TP, it has adopted the OECD Guidelines in general. Methods adopted are Comparable Uncontrolled Price (CUP), Resale Price Method (RPM), Cost Plus Method (CPM), Profit Split Method (PSM), Transactional Net Margin Method (TNMM), and the socalled sixth method, which is applicable to certain commodity transactions (the price is considered to be the market price, which is the current price of the commodity at the shipment date according to a recognised mercantile exchange).

A progressive individual income tax is levied on Argentinean residents at a top rate of 35 per cent. Withholding income tax for non-resident companies and individuals (on branch profits, dividends, interest, royalties, fees and employment income) is also applied, with rates ranging from 15 per cent to 35 per cent. A foreign tax credit is granted for both individuals and companies.

An important feature of the Argentinean tax system is the Gross Receipts Tax, which is a local tax (levied by provinces and the city of Buenos Aires). This turnover tax, which is levied on gross receipts accruing during the calendar year, is subject to a formulary apportionment methodology in order to share the tax base among the provinces (see Section 1.1, 'Corporate Gross Receipts Apportionment in Argentina' for a detailed analysis).

\section{Brazil}

Brazil is a federation of three levels: the federal government, states and municipalities are capable of imposing taxes. The Constitution splits the taxing powers as follows: the federal government may levy taxes on imports and exports, financial services, insurance and the money market, rural land property, on industrialised products (a VAT called IPI, tax rates from 0 per cent to 300 per cent, which functions as an excise tax), and the income of individuals and companies. States may levy taxes on circulation of goods and certain services (ICMA, a VAT type, with an average tax rate of 18 per cent), vehicles and inheritance and gift tax, and local governments may levy taxes on services (named ISS, with rates ranging from 2 per cent to 5 per cent, which is not a VAT), urban land property and transference of immovable property, and a contribution to public lighting.

The federal government also levies other taxes such as contributions (taxes) for specific purposes such as social security, economic intervention, and for specific economic sectors. One of these taxes is important to mention because it is similar to CIT, with basically the same basis - the so-called social contribution on the net profit (CSLL) (as a consequence, what applies to corporate income taxation in terms of regulation also applies to the CSLL, with a tax rate of 9 per cent, and 15 per cent for the financial sector). There are other important contributions on turnover called PIS/COFINS, which is cumulative for some companies (those that calculate the income tax bases in a regular manner), and cumulative for the rest. Consumption taxation in Brazil is quite complex, and it is not necessary to go into the details in this present work. ${ }^{242}$ Additional explanation on income tax follows.

Brazil assesses CIT on a worldwide basis (15 per cent rate for both resident and nonresident companies, plus 10 per cent on net profits exceeding BRL 240,000 per year and capital gains are taxed as ordinary income). Under CIT law, consolidation is not applicable. Dividends paid by resident companies are not taxed. Individual income tax is levied progressively on Brazilian residents at the top tax rate of 27.5 per cent, and capital gains are taxed at a 15 per cent tax rate. Foreign tax credit is granted for both companies and individuals (in this case, for countries with reciprocity treatment). Withholding income tax for non-resident companies and individuals (dividends, interest, royalties, fees and employment

242 For a more detailed explanation, see Valadão and Porto (2004: 716-730); Valadão (2011: 10-35); and Barreix and Villela (2003). 
income, and branch profits) is also applied, with rates ranging from 15 per cent to 25 per cent (depending on whether the beneficiary is domiciled in a low tax jurisdiction); for capital gains the rate is 15 per cent.

Brazil has also adopted anti-avoidance rules for transfer pricing (see below Table 15), thin capitalisation and CFCs. Brazilian TP entered into force in 1997 (Federal Law n. 9,430/1996) with subsequent amendments. The methodology introduced by the law adopted the traditional transaction-based methods (CUP, CPM and RPM) but denied the use of transactional profit-based methods (the PSM and TNMM, both present in the OECD TP Guidelines). Regarding CUP for export or imports, the law introduced a methodology that is similar to OECD practices, but Law n. 12,715/2012 introduced a simplification for CUP regarding commodities (which is similar to the sixth method). However, with regard to CPM and RPM, instead of making use of comparable transactions the law established fixed margins for gross profits and mark-up.

The law differentiates between import and export operations by establishing separate sets of rules for imports and exports. The fixed margins under CPM and RPM are different for import and export operations, and some operations are subject to TP adjustment only for exports, which is the case for royalties, technical assistance, and scientific and administrative fees (when they represent payments for technology transfer). There are also special rules for loans, applicable to either payment or receipt of interest, which were published in January $2013,{ }^{243}$ as a result of modifications introduced by Law 12,715/2012. Table 14 below describes the Brazilian approach vis-à-vis the OECD TP Guidelines, and UN Practical Manual (except for Chapter 10). The rates in brackets are the margins fixed by law.

\section{Table 14 Brazilian transfer pricing approach}

\begin{tabular}{|c|c|c|}
\hline \multicolumn{2}{|l|}{ Brazil } & \multirow[t]{2}{*}{ OECD/UN methods } \\
\hline Imports & Exports & \\
\hline $\mathrm{PIC} \& \mathrm{PCl}$ & PVEX \& PECEX & Comparable Uncontrolled Price (CUP) \\
\hline PRL (20\% and other margins) & PVA (15\%) \& PVV (30\%) & Resale Price Method (RPM) \\
\hline CPL (20\%) & CAP (15\%) & Cost Plus Method (CPM) \\
\hline $\mathrm{N} / \mathrm{A}$ & & $\begin{array}{l}\text { Transactional Net Margin Method } \\
\text { (TNMM) }\end{array}$ \\
\hline $\mathrm{N} / \mathrm{A}$ & & Profit Split Method (PSM) \\
\hline
\end{tabular}

PIC - Comparable Uncontrolled Price (for imports)

$\mathrm{PCl}$ - Imports with Price under Quotation Method

PVEx - Comparable Uncontrolled Price (for exports)

PECEX - Export with Price under Quotation Method

PRL - Resale Price Method (with fixed margins)

PVA - Wholesale Price in the Country of Destination Less Profit Method (with fixed margin, for exports)

PVV - Retail Price in the Country of Destination Less Profit Method (with fixed margin, for exports)

CPL - Cost Plus Method (with fixed margin, for imports)

CAP - Cost Plus Method (with fixed margin, for exports)

Transactions subject to TP regulations are those performed between related parties but not limited to them. As defined in the law and regulations, related parties are juridical persons (legal entities) or individuals that have common interests (branch, controlled companies, participation holders, exclusive distribution rights, shareholders, owners, etc.) in accordance with a set of rules established by tax regulations. The scope is broader than the OECD Guidelines and brings special rules for transactions with low tax and non-cooperative jurisdictions. ${ }^{244}$

$243 \quad$ Normative Instruction RFB n. 1.322, of 16 January 2013.

244 For details, see M. Valadão, Chapter 10.2 (358-373) of the United Nations Practical Manual on Transfer Pricing for Developing Countries. UN. 2013, available at <http://www.un.org/esa/ffd/documents/UN_Manual_TransferPricing.pdf>. For an updated version see Valadão and Lopes (2013). 


\section{Paraguay}

Paraguay is a unitary country. Its tax system is relatively young and was structured around VAT only in 1993, with a standard tax rate of 10 per cent. Paraguay also levies specific (excise) taxes. In terms of income tax, the central government has adopted CIT on a territorial basis with a 10 per cent rate. Additionally, a tax is levied at the rate of 5 per cent on the gross amount of dividends or profit distributions accrued or paid. For resident companies, capital gains are part of business income. Consolidation is not applicable. In general, a tax on capital gains is levied at 30 per cent for non-resident companies. Individual income tax is levied on Paraguay residents (those present in Paraguay for more than 120 days whether consecutively or otherwise in a given calendar year or in the previous 12 month period), and the tax rate is a flat 20 per cent. Withholding income tax for non-resident companies and individuals (including branch profits, dividends, interest, royalties, fees and employment income) is also applied, with rates varying from 15 per cent to 30 per cent. Paraguay does not apply TP regulations (see below Table 15) or CFC rules.

\section{Uruguay}

Uruguay is a unitary country. The central government levies VAT with a standard tax rate of 22 per cent. There are also excise taxes, such as on fuels. The government also levies a progressive net wealth tax on individuals and states with a top rate of 1.6 per cent. There is no inheritance or gift tax; however there is a tax on the transfer of immovable property, and specific (excise) taxes. In terms of income tax, Uruguay assesses CIT on ordinary business income and capital gains on a territorial basis at 25 per cent. Consolidation is not applicable. For non-resident companies, in general, a tax on capital gains is levied at 30 per cent, and the CIT rate is 25 per cent with a PE, and 12 per cent without a PE. Uruguayan legislation provides for TP regulations (see below Table 15) and CFC rules. TP methods adopted are CUP, RPM, CPM, PSM, TNMM and the sixth method, which is applicable to certain commodities. A progressive individual income tax is levied on Uruguay residents with a top tax rate of 30 per cent, and for capital gains the rate is 12 per cent. For non-residents, the tax rate is 12 per cent, including capital gains. Withholding income tax for non-resident companies and individuals (dividends, interest, royalties, fees and employment income) is also applied, with rates varying from 7 per cent to 30 per cent.

\section{Venezuela}

Venezuela is a unitary country. The central government levies VAT with a standard tax rate of 12 per cent, and 8 per cent for certain services. The government also levies a progressive inheritance and gift tax with a top rate of 55 per cent, depending on the relationship with the deceased or donor. Venezuela assesses a progressive CIT on ordinary business income and capital gains of both resident and non-resident companies on a worldwide basis with rates ranging from 15 per cent to 34 per cent. Capital gains tax may also include a 1 per cent final withholding tax if carried out on the stock exchange. Consolidation is not applicable. Dividends are taxed at 0 per cent provided that profits were subject to corporate tax, otherwise 34 per cent. Venezuela has adopted TP regulations (see below Table 15) following the OECD Guidelines, and APAs are also available. TP methods adopted are CUP, RPM, CPM, PSM, TNMM and the sixth method, which is applicable to certain commodities. Venezuela has also explicitly adopted the residual PSM (Esteban 2010: 17). Legislation also deals with thin capitalisation and CFC rules. A foreign tax credit is granted for both individuals and companies. A progressive individual income tax is levied on Venezuela residents and non-residents, with a top tax rate of 34 per cent. For capital gains, the rate is 34 per cent with a 1 per cent final withholding tax over the total value of sale of shares if carried out on the stock exchange. For non-resident companies and individuals there is also a 34 per cent withholding tax on interest, royalties, fees and employment income. 


\subsubsection{Application of a unitary approach for Mercosur}

The application of a unitary approach for Mercosur would be a methodology to replace the arm's length principle in regard to TP for corporate income taxation. Thus, if a member country has not adopted CIT or does not apply TP legislation, in principle there is no common ground for reform. The five Mercosur countries (considering Paraguay as member) have adopted CIT. This is a good starting point. However, as Paraguay only adopted an income tax in 2005, which came into force in 2009, and does not have TP legislation to determine adjustments when the price deviates from the arm's length standard (or other methodology), the Paraguayan approach to TP would need to be modified.

Moreover, information exchange is also necessary in the move towards unitary taxation. In terms of information exchange, Paraguay and Venezuela are not members of the Global Forum on Transparency and Exchange of Information for Tax Purposes. ${ }^{245}$ This may be a problem because information exchange is crucial for reports in order to apply the unitary approach.

Additionally, accounting standards may also be a problem regarding the use of unitary taxation with formulary apportionment. ${ }^{246}$ Although tax accounting must be consistent among the countries, financial accounting is always a reference because the two systems use the same basic accounting information. Thus, it is desirable that the countries involved share the same accounting methodologies (both for tax and financial purposes). ${ }^{247}$ Four countries of the bloc have adopted a common standard, the International Financial Reporting Standards (IFRS), though they are at different stages. ${ }^{248}$ An additional problem for Mercosur is that Paraguay is listed as a country that has not adopted IFRS. ${ }^{249}$

On the other hand, one can say that, considering a country-by-country analysis, if Paraguay adopts consistent changes in legislation to adopt TP adjustments and in accounting standards (towards the international standard), the unitary approach would be feasible for the bloc. However, in terms of common legislation within the bloc, due the lack of treaty provision (in the constituent treaties) and also considering the current stage of the integration process, a unitary approach for Mercosur is not possible in the short term. Of course, any move towards unitary taxation would require changes in internal legislation of all countries of the bloc to allow for the system to be implemented, followed by a move towards tax transparency (by adopting the Global Forum standards), and a multilateral tax treaty to regulate the issue.

\subsubsection{CAN: historical background}

In 1969, Bolivia, Chile, Colombia, Ecuador and Peru signed the Andean Pact. In 1996, the name of the organisation was changed to the Andean Community of Nations (Comunidad Andina - CAN). In 1973, Venezuela was incorporated into the bloc. In 1976, Chile withdrew

\footnotetext{
245 See information available at <http://www.oecd.org/tax/transparency/membersoftheglobalforum.htm>.

246 'Although both accounting and tax rules focus on the determination of net income, they are two separate systems with different objectives that could not, and should not, be totally aligned. Nevertheless, as the two systems are closely related to each other, any effort to reduce the gap must be welcomed, as long as the objectives of each system remain upheld' (Yussof 2014); see also Sikka and Murphy (forthcoming).

247 For tax purposes it can be achieved through a multilateral tax treaty; on the other hand, for financial accounting the issue is bit more complex. See Sikka and Murphy (forthcoming).

248 The IFRS are the standard for accounting and financial statements and reports, and coordination is through its standard-setting body, the International Accounting Standards Board. See available information at $<$ http://www.ifrs.org/Use-around-the-world/Pages/Jurisdiction-profiles.aspx>.

249 See additional information available at <http://www.ifrs.org/Use-around-the-world/Pages/Analysis-of-the-IFRSjurisdictional-profiles.aspx>. Paraguay has made a public commitment towards IFRS. IFRS reporting is permitted for companies whose securities are traded in a public market, but not required.
} 
from CAN, followed by Venezuela in $2006 .{ }^{250}$ Mauricio Baquero-Herrera summarises CAN evolution as follows:

The process of integration between the countries of Bolivia, Colombia, Ecuador, Peru and Venezuela has passed through different stages since its beginning in 1969. The Andean Pact (AP) was the first sub-regional attempt based upon now discredited inner-looking policies of import-substitution and protective Foreign Direct Investment (FDI) regulations. Although internal and external political factors played a part, implementation of the Andean Pact was primarily hindered by economic instability, and it came under deep scrutiny in 1989. During the early 1990s, a process towards the definition of a new strategic design took place. The consolidation of the Andean market as an economic area and the enhancement of the international relations of the Group within the region and with other economic blocs became the core goals of the member countries. As a result, important steps were taken to internally consolidate the Andean Integration such as the creation of the Andean Community (AC) in 1996 and the Andean President's commitment in 1999 to the goal of establishing the Andean Common Market (ACM) by 2005. (Baquero-Herrera 2004: 577-578)

The population of the bloc is around 102 million people; it has a land area of around $3,780,000 \mathrm{~km}^{2}$, with a common GDP of approximately US $\$ 500$ billion (13 per cent of South America GDP). ${ }^{251}$ The Andean Community has bodies and institutions that are coordinated by the Andean Integration System. The main bodies are the Andean Council of Presidents; the Andean Council of Foreign Ministers (responsible for the foreign policy of the Andean countries on all matters relating to the integration process); the Commission (responsible for formulating, executing and evaluating integration policies in the areas of trade and investment, it also produces laws and regulations that are binding on the four member countries); the General Secretariat; the Andean Court of Justice; the Andean Parliament (formed by 20 members, 5 from each country); the Andean Development Corporation; and the Latin American Reserve Fund. ${ }^{252}$

The Cartagena Agreement (the main CAN treaty) declares that the aim of the bloc is the gradual formation of a Latin American Common Market. It includes the national treatment principle in Article 75 and calls for the adoption of a common external tariff, but does not address tax harmonisation of direct or indirect taxes. There are, however, dispositions on integration of economic policy of the country members and harmonisation of national legislation similar to those in the Asunción Treaty in Articles 3, 54 and 57 of the Cartagena Agreement. Commission Decision 388 established rules for harmonisation of indirect taxes as well as incentives for the exportation of goods. ${ }^{253}$ In addition, Decisions of the Commission of the Andean Community (ns. 599, 600, and 635) address VAT and excise tax harmonisation. ${ }^{254}$

By means of Decision 40/1971 of the Commission of the Cartagena Agreement, a multilateral treaty was adopted to avoid double taxation (Annex I), along with a Model Convention for the CAN member states (Annex II). According to Art. 5 of Decision 40, this

\footnotetext{
250 On the reasons why Venezuela left CAN and joined Mercosur, Chris Brummer pointed out that: 'Venezuela's decision to leave the CAN for Mercosur was, as some journalists have suggested, far from naive. Founded in 1991 by the Treaty of Asuncion, the customs union between Brazil, Argentina, Uruguay, and Paraguay moves over US $\$ 150$ billion in annual trade, compared to the CAN's US $\$ 9$ billion. Even though, as mentioned above, CAN members enjoy 'associate member' status in Mercosur with certain trade benefits, full membership in Mercosur is much more valuable to Venezuela than membership in CAN (Brummer 2007: 1387).

251 World Bank, available at <http://data.worldbank.org/indicator/NY.GDP.MKTP.CD>; United Nations, available at <http://unstats.un.org/unsd/demographic/products/dyb/dyb2007/Table03.pdf>.

252 See <http://www.comunidadandina.org/en/index2.aspx>.

253 Information available at $<\mathrm{http}: / /$ www.comunidadandina.org $>$

254 Information available at <http://www.comunidadandina.org $>$.
} 
Model must be adopted by member countries when negotiating DTAs with non-member countries. ${ }^{255}$ This Decision was updated by Decision 578 of the Andean Community Commission in 2004, approving a new version of the multilateral DTA now renamed 'Scheme for the Avoidance of Double Taxation and Prevention of Fiscal Evasion', in force since 1 January 2005 for the current members of the bloc (Venezuela is no longer a member). ${ }^{256}$ The practice of this normative is subject to considerations when negotiating DTAs with third countries which have adopted either the OECD or UN Models that disregard the CAN Model Convention (Cayamana n.d: 28-37; Rodríguez and Tapia 2013).

It appears that the CAN strategy of integration, despite the fact that it has adopted a double tax model convention, does not focus on taxation as a means of fostering economic integration. CAN has formed a customs union with free circulation of goods and a common tariff schedule. Peru does not apply the common tariff schedule, and as a result was excluded from the customs union. ${ }^{257}$ The countries of the bloc have been negotiating trade treaties separately, which may weaken the cohesion of the bloc - for example, Colombia and Peru signed trade treaties with the EU in $2012 .{ }^{258}$

\subsubsection{CAN: current status and perspectives}

Although the CAN treaty does not explicitly address tax integration, the bloc has adopted a multilateral tax treaty to avoid double taxation and tax evasion and a Model Convention (which adopts the source of income principle). This level of agreement puts CAN ahead of Mercosur in terms of income tax integration.

Along with Mercosur, the Andean Community has also been negotiating trade agreements with the EU. These inter-regional negotiations could lead to increased integration and could possibly strengthen the LAIA community. However, the countries of the region, as a reaction to northern markets (North American Free Trade Agreement (NAFTA) and the EU), have formed the Union of South American Nations (UNASUR). ${ }^{259}$ The future of this process remains to be seen, but it will likely involve the whole western hemisphere, and possibly align the NAFTA countries with Mercosur, CAN and UNASUR. Regardless, at present UNASUR is more focused on political rather than economic integration.

\subsubsection{CAN: country-by-country analysis ${ }^{260}$}

This subsection addresses the tax systems of the CAN countries with a focus on income taxation and TP issues. Social contributions, payroll taxes, and other taxes levied by state or local governments are not considered here. All countries of the bloc have tax incentive schemes for some sector or operations which are also not considered here.

\footnotetext{
255 Decision n. 40, of the Commission of the Cartagena Agreement Decision, adopted on 16 November 1971, and updated by the Decision n. 578 of the Andean Community Commission, issued 4 May 2004. Information available at $<$ http://www.comunidadandina.org $>$.

256 Decision $\mathrm{n}$. 40. It is worth mentioning that among the changes in the new version of the CAN DTA is the introduction of a disposition similar to Art. 9 of the UN and OECD Model Conventions (Art. 7. Empresas Asociadas o Relacionadas [Associated Enterprises]). It allows for the application of TP adjustments (by applying the arm's length principle embodied in this article) in operations between associated enterprises in the context of the DTA.

257 Decision n. 370, of the Commission of the Cartagena Agreement (20 November 1994). Information available at $<$ http://www.comunidadandina.org $>$.

The European Commission website gives the following information: 'In June 2012 the EU signed an ambitious and comprehensive Trade Agreement with Colombia and Peru. The agreement is provisionally applied with Peru since 1 March 2013, and with Colombia since 1 August 2013. Once fully implemented, it will open up markets on both sides as well as increase the stability and predictability of the trading environment. Contacts are maintained to explore a possibility to integrate Ecuador and Bolivia, who are also members of the Andean Community, into the trade deal with the EU'. Available at <http://ec.europa.eu/trade/policy/countries-and-regions/regions/andean-community >.

259 The Constitutive Treaty of the Union of South American Nations entered into force on 11 March 2011; negotiations began in 2004, and the treaty was concluded in 2008. All 12 countries of South America joined the Association (Argentina, Bolivia, Brazil, Chile, Colombia, Ecuador, Guyana, Paraguay, Peru, Suriname, Uruguay, and Venezuela). Sources of this section: Esteban (2010); IBFD database <www.ibfd.com>.
} 


\section{Bolivia}

Bolivia is a unitary country. The central government levies VAT with a standard tax rate of 13 per cent. The government also levies a progressive inheritance and gift tax with a top rate of 20 per cent, depending on the relationship with the deceased or donor. Bolivia assesses CIT on ordinary business income and capital gains on both resident and non-resident companies on a territorial basis at 25 per cent. Consolidation is not applicable. For non-resident companies, capital gains from the sale of shares of resident companies are taxed at 12.5 per cent, but are exempt if transacted through a stock exchange. Bolivian legislation provides for TP adjustments but no regulations have been developed (see Table 16 below), and as a result no specific TP method is prescribed. Individual income tax is levied on Bolivian residents with a tax rate of 13 per cent, and a tax on business and professional activities income is levied at 25 per cent. Withholding income tax for non-resident companies and individuals applies to dividends, interest, royalties, fees, branch profits and employment income at the rate of 12.5 per cent.

\section{Colombia}

Colombia is a unitary country. The central government levies VAT with a standard tax rate of 16 per cent. A progressive net worth tax is levied on the worldwide net worth of individuals, with a top rate of 4.8 per cent. A progressive individual income tax is levied on residents, with a top rate of 33 per cent. Withholding income tax for non-resident individuals and companies on interest, royalties, fees, branch profits, and employment income is also applied, with rates ranging from 10 per cent to 33 per cent. Branch profits and dividends are taxed at 0 per cent provided that profits have been subject to corporate tax.

Colombia also assesses CIT on a worldwide basis at 25 per cent for resident companies and their PEs. Consolidation is not applicable. For non-resident companies with no PE, the tax rate is 33 per cent. Starting in 2013, resident companies and foreign companies (with a PE in Colombia) must pay additional CIT for specific purposes (Impuesto sobre la renta para la equidad (CREE)), which is levied at 9 per cent (8 per cent after 2015). A 10 per cent tax on capital gains for non-resident companies and individuals also applies. A foreign tax credit is granted for both individuals and companies.

Colombia has adopted CFC rules and TP regulations (see below Table 16). TP regulations were introduced through Law 788/2002, which inaugurated the Colombian TP regulation and follow the OECD Guidelines. For countries, which have entered into bilateral agreement with Colombia, APAs are available. Under the regulation, the TP methods adopted are CUP, RPM, CPM, PSM and TNMM. Colombia also explicitly allows the residual PSM (Esteban 2010: 17). In determining comparable transactions, factors such as transaction aspects, economic circumstances and business strategy are considered. In this context, the Colombian TP approach shares the essential concepts developed by the OECD TP guidelines: namely a functional analysis for determining the nature of the controlled transaction, and a comparability analysis between controlled and uncontrolled transactions. Finally, there is no hierarchy between the methods, which are applied according to the characteristics of the transaction.

\section{Ecuador}

Ecuador is a unitary country. The central government levies VAT with a standard tax rate of 12 per cent. The government also levies a progressive inheritance and gift tax with a top rate of 35 per cent. Ecuador assesses CIT on both ordinary business income and capital gains of resident and non-resident companies on a worldwide basis at 22 per cent but allows for a general exemption on foreign income subject to tax abroad. Consolidation is not applicable. 
Legislation also deals with thin capitalisation and CFC rules. Double taxation relief is only granted by tax treaties.

A progressive individual income tax is levied on income and capital gains of residents, with a top tax rate of 35 per cent. A foreign tax credit is granted for both individuals and companies. Withholding income tax for non-resident companies and individuals on interest, royalties, fees and employment income is also assessed at 22 per cent. Dividends and branch profits are taxed at 0 per cent, provided that profits were subject to corporate tax. Otherwise they are taxed at 22 per cent (or 35 per cent if dividends are paid to individuals domiciled in tax havens).

In term of transfer pricing, Ecuador has adopted TP regulations (see below Table 16) following the OECD Guidelines. In determining comparable transactions, two criteria are used: a) function analysis, for determining the nature of the controlled transaction; and b) comparability between controlled and uncontrolled transactions. For countries which have entered into bilateral agreements, APAs are available. TP methods adopted include CUP, RPM, CPM, PSM, TNMM and the so-called sixth method, which is applicable to certain commodities (in the case of import and export of products with publicly-established international prices, this price will be taken into consideration for determining the income imputed to the Ecuadorian party. However, taxpayers are allowed to present counterevidence. Ecuador has also explicitly adopted the residual PSM (Esteban 2010)).

\section{Peru}

Peru is a unitary country. The central government levies VAT with a standard tax rate of 16 per cent (plus 2 per cent sales tax levied at municipal level). Local governments levy a progressive tax on urban or rural immovable property with a top rate of 1 per cent. A progressive individual income tax is levied on ordinary income and capital gains of resident and non-resident individuals, with a top tax rate of 30 per cent. Withholding income tax for non-resident companies and individuals on branch profits, dividends, interest, royalties, fees and employment income is also applied with a tax rate ranging from 4.1 per cent to 30 per cent. For fees and interest paid to non-resident individuals, the tax base is 80 per cent of the gross amount.

Peru also assesses CIT on business income and capital gains of both resident and nonresident companies on a worldwide basis at 30 per cent. Consolidation is not applicable. Peru has also adopted TP regulations (see below Table 16) following the OECD Guidelines. For countries which have entered into bilateral agreements, APAs are available. TP methods adopted are CUP, RPM, CPM, PSM, residual profit split (Esteban 2010), and TNMM. There is no hierarchy between available methods, so they are applied according to the economic reality of the transaction. Legislation enacted in 2013 also deals with thin capitalisation and CFC rules. A foreign tax credit is granted for both individuals and companies.

\subsubsection{Application of a unitary approach for CAN}

In terms of information exchange, only Colombia out of the four countries of the bloc is not a member of the Global Forum on Transparency and Exchange of Information for Tax Purposes. ${ }^{261}$ This may be a problem because information is crucial in applying a unitary approach.

Accounting standards may also present a challenge for unitary taxation. It may become an additional problem for CAN because Peru and Bolivia are listed as countries that have not

261 See information available at <http://www.oecd.org/tax/transparency/membersoftheglobalforum.htm>. 
adopted IFRS. ${ }^{262}$ On the other hand, the countries of the CAN bloc have adopted a multilateral DTA, which can be a good starting point for applying the unitary approach within the bloc. Articles 6 and 7 of the CAN DTA are similar in principle to Articles 7 and 9 of the OECD and UN models (business profits and associated enterprises, respectively), which adopt the arm's length principle. Thus, one may suggest changes in these articles in order to apply a unitary taxation approach.

\subsubsection{Challenges for the application of a unitary approach for CAN and Mercosur}

The fact that there is no provision in the existent treaties, protocols, and resolutions envisaging integration of corporate income taxation presents a formidable challenge for the adoption of a regional unitary taxation approach. Furthermore, the fact that Paraguay and Uruguay of Mercosur, and Bolivia from CAN, have adopted systems of territorial taxation presents an additional obstacle to adopting a unitary approach. For those countries applying a territorial base which exempts income and gains from overseas operations and participation, the only international taxation problems they face are TP manipulation and thin capitalisation as there is no need for CFC rules. Additionally, none of the countries of either bloc allows consolidation for income tax purposes.

Another difficulty may be found in the different accounting methodologies and different stages regarding adoption of IFRS. Paraguay in Mercosur and Peru in CAN have not adopted international standards for accounting (Colombia and Bolivia are in a transition phase towards IFRS). This divergence may pose a difficulty for the adoption of unitary taxation. Moreover, tax administrations of the countries of the region are at different stages of development, especially regarding information access and publicly-available information. Among CAN countries, only Colombia is a member of the Global Forum on Tax Transparency; this may have some significance in terms of tax transparency for the bloc, which is crucial for a unitary taxation approach. This aspect is of great importance because company data is necessary to run the apportionment calculations. However, considering the numerous ways of deviating income from one country to another - even to those adopting a territorial system - a unitary taxation approach may be of interest to those countries.

\subsubsection{Conclusion}

In short, considering the tax systems outlined above and the current stage of integration of CAN and Mercosur, in the short term it is not feasible for either bloc to adopt a unitary approach. Such a transition would involve changes in internal tax legislation, and for some countries (Paraguay and Bolivia) a bit more than that. Such a transition would also require a multilateral tax treaty dealing specifically with the issue of unitary taxation to replace internal legislation. Because CAN has adopted a double tax treaty that is in force, which provides for arm's length principle (similar to Article 9 of the OECD and UN Models), one can say that CAN is closer than Mercosur to moving towards unitary taxation within the bloc, despite the political divergences that this move may trigger.

See available information at <http://www.ifrs.org/Use-around-the-world/Pages/Jurisdiction-profiles.aspx>. Colombia has adopted IFRS as mandatory for listed companies starting 2014 (transition for other companies to be completed in 2016); Bolivia currently adopts a regional standard, but has made a public commitment towards IFRS, and currently adopts it for some companies. There is information that Peru is planning to move towards the adoption of IFRS. See, e.g., <http://www.ifrs.org/IFRS-for-SMEs/Documents/1112SMEChileEducators.pdf>, and <http://www.ifrs.org/Theorganisation/Governance-and-accountability/Annual-reports/Documents/IFRSANNUALREPORT_ALL_12July.pdf>. 
Table 15 Mercosur transfer pricing legislation by country - current stage and other features

\begin{tabular}{|c|c|c|c|c|c|c|c|c|c|c|}
\hline Country & $\begin{array}{l}\text { Adopts TP } \\
\text { regulations } \\
\text { and year }\end{array}$ & Methods adopted & APA & $\begin{array}{l}\text { Documentation } \\
\text { legislation }\end{array}$ & $\begin{array}{l}\text { Safe } \\
\text { harbours }\end{array}$ & $\begin{array}{l}\text { Follows } \\
\text { OECD } \\
\text { Guidelines }\end{array}$ & $\begin{array}{l}\text { Territorial } \\
\text { or } \\
\text { worldwide } \\
\text { income } \\
\text { taxation }\end{array}$ & $\begin{array}{l}\text { Double } \\
\text { tax } \\
\text { treaties } \\
\text { in force }\end{array}$ & $\begin{array}{l}\text { Member } \\
\text { of the } \\
\text { OECD } \\
\text { Global } \\
\text { Forum }\end{array}$ & $\begin{array}{l}\text { IFRS } \\
\text { adoption }\end{array}$ \\
\hline Argentina & $\begin{array}{l}\text { Yes } \\
\text { (Ley } \\
25,063 / 1998 \\
\text { as } \\
\text { amended) }\end{array}$ & $\begin{array}{l}\text { CUP, CPM, RPM, } \\
\text { PSM, TNMM, and } 6^{\text {th }} \\
\text { method for } \\
\text { commodities }\end{array}$ & No & $\begin{array}{l}\text { Yes/1988 } \\
\text { Specific return/ } \\
\text { documentation } \\
\text { on controlled } \\
\text { transactions }\end{array}$ & No & $\begin{array}{l}\text { Yes } \\
\text { (except for the } \\
6^{\text {th }} \text { method) }\end{array}$ & Worldwide & 15 & Yes & Yes \\
\hline Brazil & $\begin{array}{l}\text { Yes/1995 } \\
\text { (Lei n. } \\
9.430 / 1996 \\
\text { as } \\
\text { amended) }\end{array}$ & $\begin{array}{l}\text { CUP, CPM and RPM } \\
\text { with fixed margins. } \\
\text { Profit transactional } \\
\text { methods are not } \\
\text { allowed (TNNM and } \\
\text { profit split). } \\
\text { Brazil also adopts an } \\
\text { specific method for } \\
\text { commodities, which is } \\
\text { deemed to be a } \\
\text { special methodology } \\
\text { for CUP }\end{array}$ & $\begin{array}{l}\text { No; } \\
\text { however, } \\
\text { taxpayer can } \\
\text { apply for } \\
\text { modification } \\
\text { of the fixed } \\
\text { margin for } \\
\text { particular } \\
\text { cases }\end{array}$ & $\begin{array}{l}\text { Brazil/1995 } \\
\text { Controlled } \\
\text { transactions } \\
\text { informed with } \\
\text { the tax return }\end{array}$ & Yes & No & Worldwide & 30 & Yes & Yes \\
\hline Paraguay & No & --------- & ------------ & -------- & --------- & ---------- & Territorial & 2 & No & $\begin{array}{l}\text { Elective } \\
\text { for } \\
\text { companies } \\
\text { with } \\
\text { publicly- } \\
\text { traded } \\
\text { securities }\end{array}$ \\
\hline Uruguay & $\begin{array}{l}\text { Yes } \\
\text { Ley } \\
\text { 18.083/2006 }\end{array}$ & $\begin{array}{l}\text { CUP, CPM, RPM, } \\
\text { PSM, TNMM, and } 6^{\text {th }} \\
\text { method for } \\
\text { commodities }\end{array}$ & Yes & $\begin{array}{l}\text { Yes/2005 } \\
\text { Specific return/ } \\
\text { documentation } \\
\text { on controlled } \\
\text { transactions }\end{array}$ & Yes & $\begin{array}{l}\text { Yes } \\
\text { (except for the } \\
6^{\text {th }} \text { method) }\end{array}$ & Territorial & 12 & Yes & Yes \\
\hline Venezuela & $\begin{array}{l}\text { Yes } \\
\text { LIR/1999 }\end{array}$ & $\begin{array}{l}\text { CUP, CPM, RPM, } \\
\text { PSM, residual profit } \\
\text { split, TNMM, and } 6^{\text {th }} \\
\text { method for } \\
\text { commodities }\end{array}$ & Yes & $\begin{array}{l}\text { Yes/2000 } \\
\text { Specific return/ } \\
\text { documentation } \\
\text { on controlled } \\
\text { transactions }\end{array}$ & No & $\begin{array}{l}\text { Yes } \\
\text { (except for the } \\
6^{\text {th }} \text { method) }\end{array}$ & Worldwide & 31 & No & Yes \\
\hline
\end{tabular}

Notes: In all countries taxpayer must present documentation related to controlled transactions when requested by the tax administration. Does not include Tax Information Exchange Agreements. 
Table 16 CAN transfer pricing legislation by country - current stage and other features

\begin{tabular}{|c|c|c|c|c|c|c|c|c|c|c|}
\hline Country & $\begin{array}{l}\text { Adopts TP } \\
\text { regulations } \\
\text { and year }\end{array}$ & Methods adopted & APAs & $\begin{array}{l}\text { Documentation } \\
\text { legislation }\end{array}$ & $\begin{array}{l}\text { Safe } \\
\text { harbours }\end{array}$ & $\begin{array}{l}\text { Follows } \\
\text { OECD } \\
\text { Guidelines }\end{array}$ & $\begin{array}{l}\text { Territorial or } \\
\text { worldwide } \\
\text { income } \\
\text { taxation }\end{array}$ & $\begin{array}{l}\text { Number of } \\
\text { double tax } \\
\text { treaties } \\
\text { in force }\end{array}$ & $\begin{array}{l}\text { Member } \\
\text { of the } \\
\text { OECD } \\
\text { Global } \\
\text { Forum }\end{array}$ & IFRS adoption \\
\hline Bolivia & $\begin{array}{l}\text { Yes } \\
\text { Ley 843/2004 } \\
\text { (Art. 37) as } \\
\text { amended }\end{array}$ & $\begin{array}{l}\text { Legislation refers to } \\
\text { the arm's length } \\
\text { principle generally }\end{array}$ & No & Not available & $\begin{array}{l}\text { Yes } \\
\text { (loans) }\end{array}$ & Not explicitly & Territorial & 6 & No & $\begin{array}{l}\text { Currently adopts a } \\
\text { regional standard, } \\
\text { but has made a } \\
\text { public commitment } \\
\text { towards IFRS, and } \\
\text { currently allows } \\
\text { IFRS reporting for } \\
\text { some companies }\end{array}$ \\
\hline Colombia & $\begin{array}{l}\text { Yes/2002 } \\
\text { Ley } 788 / 2002\end{array}$ & $\begin{array}{l}\text { CUP, CPM, RPM, } \\
\text { PSM, residual profit } \\
\text { split, and TNMM }\end{array}$ & Yes & $\begin{array}{l}\text { Yes/2001 } \\
\text { Specific return/ } \\
\text { documentation } \\
\text { on controlled } \\
\text { transactions }\end{array}$ & No & Yes & Worldwide & 5 & Yes & $\begin{array}{l}\text { Yes: mandatory } \\
\text { for listed } \\
\text { companies starting } \\
2014 \text {, transition to } \\
\text { be completed by } \\
2016\end{array}$ \\
\hline Ecuador & Yes & $\begin{array}{l}\text { CUP, CPM, RPM, } \\
\text { PSM, residual profit } \\
\text { split, TNMM, and } 6^{\text {th }} \\
\text { method for } \\
\text { commodities }\end{array}$ & Yes & $\begin{array}{l}\text { Yes } \\
\text { (non-specific) }\end{array}$ & No & $\begin{array}{l}\text { Yes } \\
\text { (except for } \\
\text { the } 6^{\text {th }} \\
\text { method) }\end{array}$ & Worldwide & 13 & No & Yes \\
\hline Peru & $\begin{array}{l}\text { Yes/2003 } \\
\text { Leg. Decree } \\
\text { 945/2003 }\end{array}$ & $\begin{array}{l}\text { CUP, Cost Plus, } \\
\text { Resale Price, Profit } \\
\text { Split, residual profit } \\
\text { split, and TNMM. }\end{array}$ & Yes & $\begin{array}{l}\text { Yes/2003 } \\
\text { Specific return/ } \\
\text { documentation } \\
\text { on controlled } \\
\text { transactions }\end{array}$ & No & Yes & Worldwide & 3 & No & No \\
\hline
\end{tabular}

Notes: In all countries the taxpayer must present documentation related to controlled transactions when requested by the tax administration. The four CAN countries have a multilateral tax treaty to avoid double taxation and tax evasion (which is not included here). This does not include Tax Information Exchange Agreements. 


\section{Conclusion}

In the last century, the federations of the US, Canada and Switzerland created tax systems which enabled economic integration through greater tax coordination. In this century, regional economic integration has now become the trend in today's global economy. In adapting to a global economy, the EU CCCTB proposal is a front-runner in responding to regional economic integration through tax base harmonisation, consolidation and apportionment on a regional level. This paper has sought to analyse these tax systems and explore the advantages and challenges in the dissemination of the unitary approach for regional economic communities in the Global South. Based on this examination, we conclude that the EU CCCTB proposal offers the most transferable model for tax base harmonisation, consolidation and apportionment for market integration, because this scheme enables an equitable sharing of the tax base among member states and ensures the free flow of goods, services and capital. However, the final outcome of the proposal remains to be seen as negotiations are far from complete.

Development of the tax base definition, consolidation criteria, and formula factors and weighting, however, are all areas requiring political agreement and should be based on studies of regional economic impact. Even with political agreement on these issues, unitary taxation does not offer the panacea of complete tax neutrality. Only full uniformity of the tax rates and base, and incentives/subsidies, can accomplish this feat. Thus, in balancing national/state sovereignty with market integration, unitary taxation presents a solution in the middle ground. Manipulation of tax incentives and rates based on formula factors may allow a certain level of tax competition. However, this type of competition would be more transparent and based on factors of economic value creation in relation to the unitary enterprise, as opposed to manipulation of internal prices between artificially-segmented entities for the purpose of shifting profits to low tax and secrecy jurisdictions. 


\section{References}

Abel, A. (1941) 'The Commerce Clause in the Constitutional Convention and in Contemporary Comment', Minnesota Law Review 25: 432-

Anand, B. and Sansing, R. (2000) 'The Weighting Game: Formula Apportionment as an Instrument of Public Policy', National Tax Journal 53(2): 183-199

ASEAN (2008) ASEAN Economic Community Blueprint, Jakarta: ASEAN Secretariat

Balassa, B. (1961) The Theory of Economic Integration, Irwin series in economics, Homewood IL: RD Irwin

Baquero-Herrera, M. (2004) 'The Andean Community: Finding Her Feet Within Changing and Challenging Multidimensional Conditions', Law and Business Review of the Americas 10: 577-612

Barreix, A. and Villela, L. (2003) Tributación en el Mercosur: Evolución, comparación y possibilidades de coordinación [Taxation In the Mercosur: Evolution, Comparison, and Coordination Possibilities], Buenos Aires: IDB/INTAL/ITD

Brummer, C. (2007) 'The Ties That Bind? Regionalism, Commercial Treaties, and the Future of Global Economic Integration', Vanderbilt Law Review 60(5): 1349-1408

Cayamana, R. (n.d.) Los convenios para evitar la doble imposición y prevenir la evasión fiscal com énfasis em los convênios vigentes em el Perú [Agreements to avoid double taxation and prevent fiscal evasion emphasis on existing conventions in Peru], available at $<$ http://www.ifaperu.org/uploads/articles/316_01_manual_cdi.pdf>

Clausing, K. (2014) Lessons for International Tax Reform from the US State Experience under Formulary Apportionment, ICTD Research Report 2, Brighton: International Centre for Tax and Development

Cnossen, S. (2013) 'Reform and Coordination of Indirect Taxes in the ASEAN Free Trade Area', Tax Notes International 69: 589-591

Coase, R. (1937) 'The Nature of the Firm', Economica 4(16): 386-405

Commission of the European Communities (1992) Report of the Committee on Independent Experts on Company Taxation, Brussels: Office for Official Publications of the European Communities

Daly, M. and Weiner, J. (1993) 'Corporate Tax Harmonization and Competition in Federal Countries: Some Lessons for the European Community?', National Tax Journal 46(4): 441-61

Department of Finance Canada (2010) The Taxation of Corporate Groups, Consultation Paper

_ (1985) A Corporate Loss Transfer System for Canada, Discussion Paper 
Duncan, H. (2005) Relationships between Federal and State Income Taxes, Washington DC: Federation of Tax Administrators

Dunning, J. (1988) 'The Eclectic Paradigm of International Production: A Restatement and Some Possible Extensions', Journal of International Business Studies 19(1): 1-31

East African Community (2011) $4^{\text {th }}$ EAC Development Strategy (2011/12-2015/16). Deepening and Accelerating Integration, Arusha: East African Community

Ernst \& Young (2013) Worldwide Corporate Tax Guide

Esteban, I. (2010) Estudio Comparado sobre la Situación actual de las Legislaciones de Precios de Transferencia en Latinoamérica [Comparative Study on the Current Situation of Transfer Pricing Legislation in Latin America], CIAT

European Commission (1994) Report of US Barriers to Trade and Investment, Doc. No. 1/94/94

Farrand, M. (ed) (1911) The Records of the Federal Convention of 1787, Vol. 3, New Haven: Yale University Press

Federal Chancery (2013) The Swiss Confederation: A Brief Guide

Federal Department of Finance (2013), Federal, Cantonal and Communal Taxes: An Outline on the Swiss System of Taxation, Swiss Federal Tax Administration, Division of Analysis and Data

Filho, A. and Catão, M. (2001) Harmonização Tributária no Mercosul [Tax Harmonization in Mercosur], São Paulo: Aduaneiras

González, D., Martinoli, C. and Pedraza, J. (2009) Sistemas Tributarios de América Latina: situación actual, reformas y politicas para promover la cohesión social [Tax Systems in Latin America: current situation and policy reforms to promote social cohesion], Madrid: IEF

Griffith, C. and Sawyer, D. (2014) 'The Exchange of Information Among Tax Authorities', in Tax Analysts, US State Tax Considerations for International Tax Reform

Hellerstein, W. (2005) 'Income Allocation in the 21st Century: The End of Transfer Pricing? The Case for Formulary Apportionment', International Transfer Pricing Journal 12(3):103-111

Huddleston, J. and Sicilian, S. (2009) The Project to Revise UDITPA, from the Proceedings of the New York University Institute on State and Local Taxation

Isaacs, E. (1926) 'The Unit Rule’, Yale Law Journal 35: 838

Kagyenda, B. (n.d.) Development of an EAC Model Agreement for the Avoidance of Double Taxation and An EAC Code of Conduct against harmful tax competition, a final report prepared for the EAC secretariat, GIZ - EAC Tax Harmonisation

Mclntyre, M. and Pomp, R. (1995) ‘GATT, Barclays, and Double Taxation’, State Tax Notes 8: 977-980 
McLure Jr., C. (1977) The State Corporate Income Tax: Lambs in Wolves' Clothing, Office of Tax Analysis Paper 25

Mattera, P. and Tarczynska, K. (2013) 'Megadeals: The Largest Economic Development Subsidy Packages Ever Awarded by State and Local Governments in the United States', Good Jobs First

Mayer, S. (2009) Formulary Apportionment for the Internal Market, IBFD Doctoral Series vol.17

Mazerov, M. (2003) 'Closing Three Common Corporate Income Tax Loopholes Could Raise Additional Revenue for Many States', Center on Budget and Policy Priorities, 23 May 2003

Mintz, J. and Smart, M. (2004) 'Income shifting, investment, and tax competition: theory and evidence from provincial taxation in Canada', Journal of Public Economics 88(6): 11491168

Mutsotso, C. (2010) Harmonisation of EAC Tax Policies and Laws. Proposals for Taxation Regime for Fostering Small Enterprise Development and Regional Economic Growth, CUTS GRC Research Paper

Ontario Ministry of Finance (2011), Taxation of Corporate Groups in Canada (21 April 2011)

Pastor, R. (2001) Toward a North American Community: Lessons from the Old World for the New, Institute for International Economics

Peres, E. (2002) O preço de transferência e a harmonização tributária no Mercosul [Transfer pricing and tax harmonisation in Mercosur], Rio de Janeiro: Lumen Juris

Peterson, H-G. (ed) (2010) Tax Systems and Tax Harmonisation in the East African Community (EAC): Report for the EAC/GTZ program 'Support to the EAC integration process', Finanzwissenschaftliche Diskussionsbeiträge, No. 60, <http://www.econstor.eu/bitstream/10419/39673/1/630944601.pdf>

Picciotto, S. (2013) Is International Tax System Fit for Purpose, Especially for Developing Countries?, ICTD Working Paper 13, Brighton: International Centre for Tax and Development

Pomp, R. (2009) State and Local Taxation, $6^{\text {th }}$ edition, VI. 2

PriceWaterhouseCoopers LLP (2011), Taxation of Corporate Groups: Submission to the Department of Finance (11 April 2011)

Quintanilla Ballivián, E. (2013) Political Risk Management and Sustainability in Latin American Natural Resource Projects, International Mining and Oil \& Gas Law, Development and Investment Paper No. 3A, Rocky Mountain Mineral Law Foundation

Radaelli, C. (1997) The Politics of Corporate Taxation in the European Union: knowledge and international policy agendas, New York: Routledge 
Ramah, R. (2013) ‘Double taxation pinches East African businesses with regional reach', Sabahi Online, 18 June 2013, available at <http://sabahionline.com/en_GB/articles/hoa/articles/features/2013/06/18/feature-02> accessed 24 September 2013

Richardson, S. and Smart, M. (2013) Tax Loss Utilization and Corporate Groups: A Policy Conundrum, University of Calgary School of Public Policy Research Papers 6(3)

Rodríguez, M. and Tapia, L. (2013) Análisis Tributario y Contable para Evitar la Doble Tributación del Convenio Firmado por el Ecuador con los Países Miembros de la Comunidad Andina de Naciones [Tax and Accounting Analysis for Avoidance of Double Taxation Agreement signed by Ecuador with the Member Countries of the Andean Community of Nations], thesis, Universidade de Cuenca (2013). Available at <http://dspace.ucuenca.edu.ec/handle/123456789/4042>

Saldanha, E. (2008) Harmonização Legislativa Tributária no Mercosul e na União Européia [Legislative Tax harmonisation in Mercosur and the European Union], Curitiba: Juruá

Sikka, P. and Murphy, R (forthcoming) Unitary Taxation: Tax Base and the Role of Accounting

Simonek, M. (2012) 'Tax Coordination between Cantons in Switzerland - Role of the Courts, in M. Lang, P. Pistone, J. Schuch and C. Staringer (eds), Horizontal Tax Coordination, IBFD

United Nations (2013) Practical Manual on Transfer Pricing for Developing Countries, New York NY: United Nations

US Government Accountability Office (2013) Corporate Income Tax. Effective Tax Rates Can Differ Significantly from the Statutory Rate, May 2013

Valadão, M. (2011) 'Globalization Effects on the Brazilian Tax System' in M. Valadão and A. Borges (ed), Brazil, Russia, India, China (BRIC): Tax system structures and the effects on development and foreign trade performance lessons and solutions, 1ed. Brasilia: ABDI

- (2009) 'Washington Consensus And Latin America Integration: Mercosur And The Road To Regional Inconsistencies--To Where Are We Going Exactly?', Law and Business Review of the Americas 15(1): 207-220

— and Lopes, R. (2013) 'Transfer Pricing in Brazil and the Traditional OECD Approach', International Taxation 9: 57-67

and Porto, N. (2004) 'MERCOSUR, NAFTA, FTAA and its Effects in Federal Taxation Of International Transactions Between the United States and Brazil: A Comparative Study', Law and Business Review of the Americas 10: 705-

and van Thiel, S. (2012) 'Selected EU Laws and Procedural Issues', in KPMG, The KPMG Guide to CCCTB, Part I, available at:

$<$ http://www.kpmg.com/Global/en/lssuesAndlnsights/

ArticlesPublications/Documents/ccctb-part1-v2.pdf>

Weiner, J. (2005) Formulary Apportionment and Group Taxation in the European Union: Insights from the United States and Canada, European Commission Taxation Papers, 
Working Paper No. 8/2005, Luxembourg: Office for Official Papers of the European Communities

Wishlade, F. (2012) 'When Policy Worlds Collide: Tax Competition, State Aid, and Regional Economic Development in the EU', European Integration 34(6): 585-602

Yussof, S. (2014) 'Malaysia - The Intersection of Accounting and Taxation in Malaysia', Bulletin for International Taxation 68(1) 


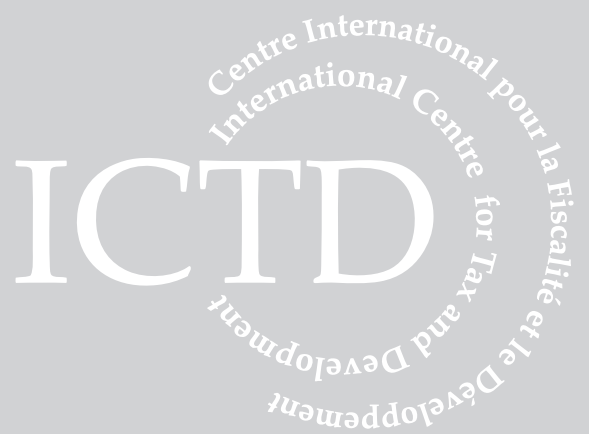

International Centre for Tax and Development at the Institute of Development Studies

Brighton BN1 9RE, UK

T: +44 (0) 1273606261

F: $+44(0) 1273621202$

E: info@ictd.ac

www.ictd.ac 